El jurado designado por la División de Ciencias Biológicas y de la Salud de la Unidad Iztapalapa aprobó la tesis

\title{
Efecto de los exopolisacáridos producidos por Streptococcus thermophilus en la elaboración de queso tipo Manchego
}

que presentó

\section{M. en C. Diana Lluis Arroyo}

Comité Tutoral:

Director: Dr. José Mariano García Garibay

Asesora: Dra. Judith Jiménez Guzmán

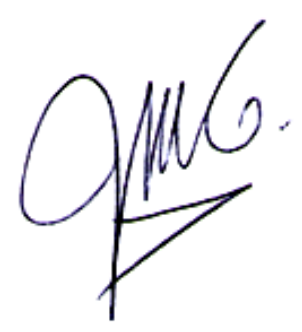

Asesora: Dra. Consuelo Silvia Olivia Lobato Calleros

Jurado:

Presidente: Dra. Gabriela Mariana Rodríguez Serrano

Secretario: Dr. Héctor Bernardo Escalona Buendía

Vocal: Dra. Consuelo Silvia Olivia Lobato Calleros

Vocal: Dr. Humberto Hernández Sánchez

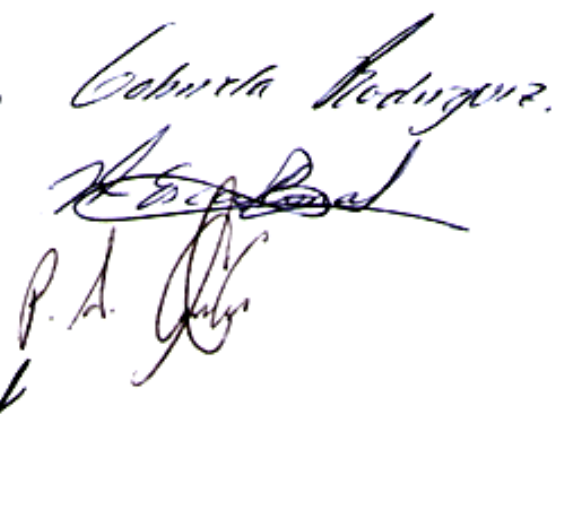




\title{
UNIVERSIDAD AUTÓNOMA METROPOLITANA
}

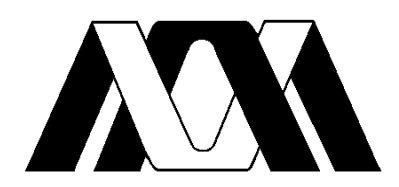

Casa abierta al tiempo

UNIDAD IZTAPALAPA

DIVISIÓN DE CIENCIAS BIOLÓGICAS Y DE LA SALUD

\section{Efecto de los exopolisacáridos producidos por Streptococcus thermophilus en la elaboración de queso tipo Manchego}

\author{
T $\quad$ E $\quad \mathbf{S} \quad \mathbf{I} \quad \mathbf{S}$ \\ PARA OBTENER EL GRADO DE \\ DOCTOR EN BIOTECNOLOGÍA \\ P R E S E N T A: \\ Mtra. Diana Lluis Arroyo \\ DIRECTOR: \\ Dr. Mariano García Garibay
}


"El Doctorado en Biotecnología de la Universidad Autónoma Metropolitana está incluido en el Programa Nacional de Posgrados de Calidad (PNPC) del CONACyT, con la referencia 001466”. 
El jurado designado por la División de Ciencias Biológicas y de la Salud de la Unidad Iztapalapa aprobó la tesis

\title{
Efecto de los exopolisacáridos producidos por Streptococcus thermophilus en la elaboración de queso tipo Manchego
}

\author{
que presentó \\ M. en C. Diana Lluis Arroyo
}

\section{Comité Tutoral:}

Director: Dr. José Mariano García Garibay

Asesora: Dra. Judith Jiménez Guzmán

Asesora: Dra. Consuelo Silvia Olivia Lobato Calleros

\section{Jurado:}

Presidente: Dra. Gabriela Mariana Rodríguez Serrano

Secretario: Dr. Héctor Bernardo Escalona Buendía

Vocal: Dra. Consuelo Silvia Olivia Lobato Calleros

Vocal: Dr. Humberto Hernández Sánchez 


\section{AGRADECIMIENTOS}

Agradezco a todas las personas que me orientaron, guiaron, impulsaron y animaron en esta labor.

Al Dr. Mariano García Garibay, por su valiosa dirección de este proyecto, por brindarme su ayuda, sus conocimientos y paciencia en la realización de este trabajo.

A la Dra. Consuelo S. O. Lobato Calleros, por su apreciable asesoría y por su dedicación y ayuda a lo largo de esta investigación.

A la Dra. Judith Jiménez Guzmán, por su valiosa asesoría y apoyo en la realización de este trabajo.

Al Dr. Francisco Gallardo ${ }^{\dagger}$ por sus inestimables aportaciones en las tareas relacionadas con el análisis de datos y estadística.

A la Mtra. Lorena, la Dra. Alma y la Dra. Gaby, por su comprometido apoyo y consejos para la realización de este trabajo.

A mis compañeros de la Planta Piloto 2, Claudia, Nataly, Becky, Luis y Christian, por toda su ayuda, consejos y amistad, y en especial a Ivonne por sus sugerencias y amistad. A Angélica, por su colaboración en el desarrollo de este trabajo.

A la Mtra. Alma Angélica Martínez, Directora de la ENP No. 6 "Antonio Caso", por el enorme apoyo que me brindó en la ejecución de este trabajo y por su invaluable amistad.

Al Dr. Héctor Lomelí, por sus consejos, orientación y ayuda en la elaboración de este trabajo.

A la Universidad Autónoma Metropolitana, por darme la oportunidad de formar parte de su programa de Doctorado.

Al CONACyT por la beca otorgada para cursar y concluir los estudios de Doctorado.

A la Escuela Nacional Preparatoria No. 6 "Antonio Caso", de la UNAM, por el tiempo que me otorgó para poder desarrollar mis estudios. 


\section{DEDICATORIAS}

A mis padres Otilia $^{\dagger}$ y Jorge ${ }^{\dagger}$, que fueron siempre un ejemplo para mí de su dedicación al estudio y al trabajo; por acompañarme y hacerme crecer.

A mis hermanas Helena, Tety, Gena, Irene y Mónica, por su sostén y comprensión a lo largo de todo este trabajo, y por su compañía y amor incondicional que siempre me ha ayudado a salir adelante. En especial a Helena por la corrección de estilo y a Irene por escucharme y aconsejarme constantemente.

A mis compañeros de camino Amedeo, Lupita, César, René, Giovanna, Lulú, Leslie, Rossana, Mariangela, Manuela, Stefano y $\mathrm{Bruno}^{\dagger}$, por su valiosa compañía y por recordarme a cada paso las cosas importantes de la vida. En especial a Amedeo por ser como un padre para mí.

A Franco, por su valiosa amistad y consejo, por estar siempre disponible para escucharme, acompañarme y sostenerme en este camino.

A Julián, Javier y Roberto, por ser un continuo testimonio en mi vida.

A María Rosa, por su amistad y acompañamiento en este tiempo.

A mis amigos de Comunión y Liberación, quienes me han recordado siempre la razón por la cual vale la pena seguir adelante.

A Don Luigi Giussani ${ }^{\dagger}$ y a Julián Carrón, por sus enseñanzas, acompañamiento y guía perennes.

A todos mis alumnos, por lo mucho que he aprendido de ellos a lo largo de estas generaciones. 


\section{RESUMEN}

Se evaluó el efecto de los exopolisacáridos (EPS) producidos por Streptococcus thermophilus SY-102 en la elaboración de queso mexicano tipo manchego. Como resultado principal, se encontró que la mencionada cepa filante mejoró la retención de agua y de grasa del queso, y por lo tanto, aumentó significativamente su rendimiento. Además, en el queso elaborado con cepa filante hubo mayor retención de humedad durante la maduración, lo que indica que los EPS se unen fuertemente al agua dentro de la matriz de proteínas del queso.

Como parte del trabajo experimental se utilizó microscopía electrónica de barrido (SEM) para confirmar que los EPS unidos a la matriz de proteínas del queso produjeron una red densa que ayudó a aumentar la retención de agua y grasa. Esta retención generó una estructura más abierta en el queso que da como resultado final un producto más blando.

La comparación de las micrografías SEM de las diferentes secciones del queso mostró mayor concentración de EPS en el centro respecto a las secciones exteriores. Esta diferencia de concentración indica que la producción de EPS continuó durante la maduración y que el ambiente de humedad y/o concentración de oxígeno en el centro del queso favoreció su producción.

En el análisis de perfil de textura (APT) — que es un método instrumental— se encontró que el queso elaborado con cepa filante resultó ser menos duro, más cohesivo y menos elástico que el queso control; en cambio, los EPS no afectaron la masticabilidad. Los cambios en la textura se relacionaron con la composición. Se encontró que cuando la cantidad de agua y grasa disminuyen, se incrementa la dureza, mientras que la elasticidad disminuye cuando se incrementa la cantidad de grasa. También se observó que hubo un aumento en la cohesividad del queso elaborado con cepa filante debido a las interacciones de los EPS con la matriz proteica.

Asímismo se realizó una evaluación sensorial aplicando un Análisis Descriptivo Cuantitativo donde se midieron los mismos atributos que en el Análisis del Perfil de Textura, mediante un panel diez jueces entrenados. En este caso se obtuvo que el queso filante resultara ser menos firme y menos cohesivo en comparación con el queso control, mientras que la 
elasticidad resultó significativamente mayor. Por otro lado, no se percibieron diferencias significativas en la masticabilidad.

Por todo lo dicho anteriormente podemos concluir que el uso de una cepa de Streptococcus thermophilus productora de EPS en la elaboración de queso tipo manchego ayudó a retener agua y grasa, lo cual influyó en un mayor rendimiento del mismo. También el uso de esta cepa modificó su textura resultando un queso menos duro. 


\section{ABSTRACT}

An exopolysaccharide (EPS)-producing a strain of Streptococcus thermophilus was evaluated in the production of Mexican manchego-type cheese. This ropy strain improved water and fat retention, significantly increasing cheese yield. Furthermore, the ropy strain cheese retained more moisture than control cheese during ripening, suggesting that EPS strongly bound water within the protein matrix of the cheese. Scanning Electron Microscopy (SEM) confirmed that EPS bound to the protein matrix of the cheese, producing a dense network that helped to increase water and fat retention and leading to a more open structure of the cheese that gave out a softer product, as confirmed by instrumental texture profile analysis (TPA) and sensory evaluation.

Comparison of SEM micrographs of the different sections of the cheese showed higher concentration of EPS in the centre than in the outer sections, indicating that EPS production continued during ripening and that the environment at the centre of the cheese (moisture and/or oxygen concentration) favored EPS production. Instrumental TPA also demonstrated that the ropy strain cheese was more cohesive and less elastic than control; in contrast, EPS did not affect chewiness. The changes in texture could be correlated to composition, as hardness increased as water and fat decreased, while springiness decreased with increasing fat. The interactions of EPS with the cheese protein matrix had an effect on the increase in cohesiveness of the ropy strain cheese.

Likewise, a sensorial evaluation was performed by applying a Quantitative Descriptive Analysis, where a board of ten trained judges measured the same features in the TPA. In this case, the results depicted that the ropy strain cheese was less solid and less cohesive, compared with the control cheese, while its elasticity was significantly greater. No meaningful differences in chewiness were perceived.

As a result, one can conclude that the use of a strain of Streptococcus thermophilus, producing EPS in the making of manchego-type cheese helped to retain water and fat, which influenced the production of a higher yield of the mentioned product. Also, the use of the EPS strain modified the texture of the cheese, resulting in a harder product. 


\section{ABREVIATURAS}

EPS. Exopolisacáridos

BAL. Bacterias ácido lácticas

SEM. Microscopía electrónica de barrido

APT. Anáisis del perfil de textura

LC. Leche madurada con cepa control (Streptococcus thermophilus no productor de EPS)

LF. Leche madurada con cepa filante (Streptococcus thermophilus productor de EPS)

QC. Queso control elaborado con Streptococcus thermophilus no productor de EPS

QF. Queso filante elaborado con Streptococcus thermophilus productor de EPS

SNG. Sólidos no grasos

GBS. Grasa base seca

SNGBS. Sólidos no grasos base seca

ANOVA. Análisis de varianza

ACP. Análisis de componentes principales

CSLM. Microscopia láser confocal de exploración 


\title{
ÍNDICE GENERAL
}

\author{
CAPÍTULO I
}

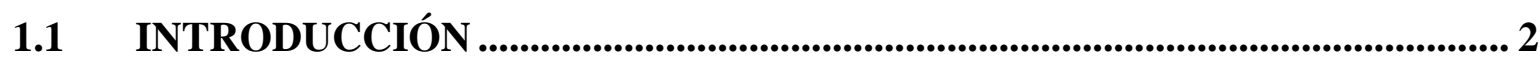

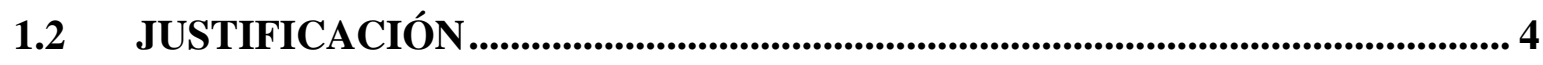

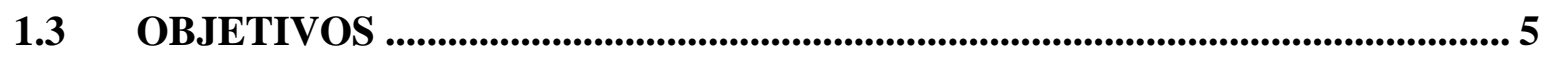

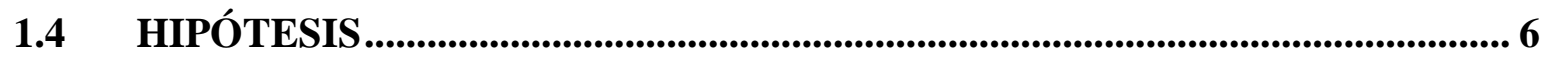

\section{CAPÍTULO II. ANTECEDENTES}

2.1 GENERALIDADES DEL QUESO ......................................................................... 8

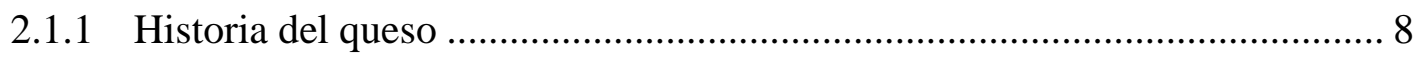

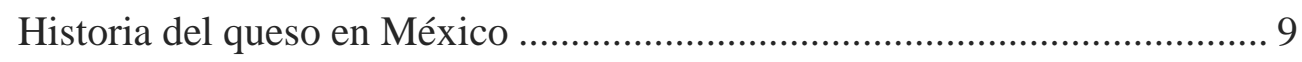

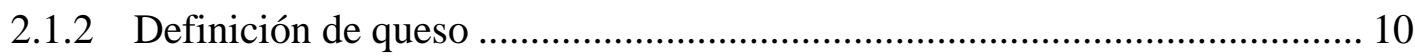

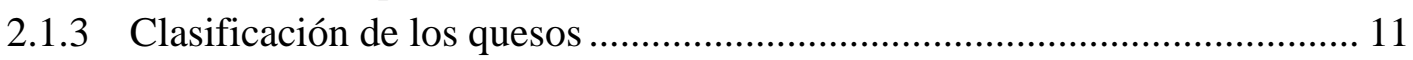

2.1.4 Composición fisicoquímica y valor nutritivo del queso ………………….... 12

2.1.5 Composición fisicoquímica y características de algunos

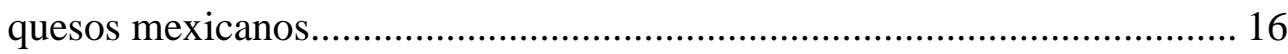

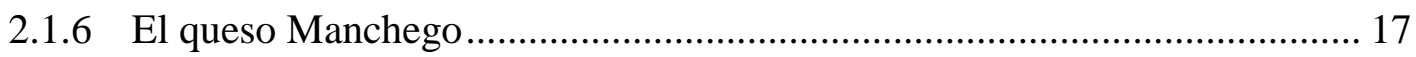

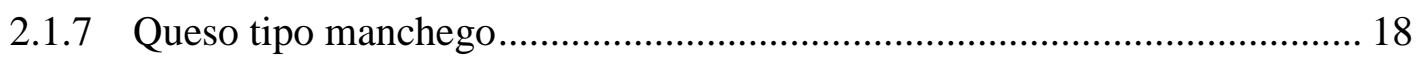

2.1.8 Elaboración de queso tipo manchego ………………………………....... 19

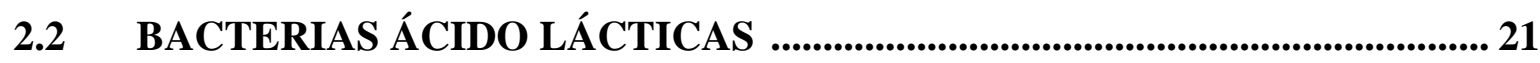

2.2.1 Características generales de las bacterias ácido lácticas (BAL) …………... 21

2.2.2 Bioquímica de las bacterias ácido lácticas (BAL) ...................................... 23

2.2.3 Cultivos iniciadores para la elaboración de queso ......................................... 24

2.3 BACTERIAS ÁCIDO LÁCTICAS PRODUCTORAS DE

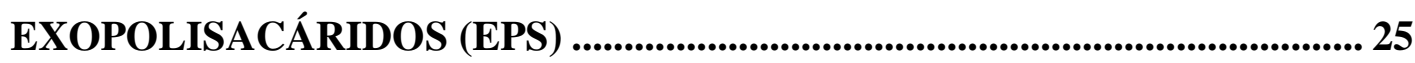

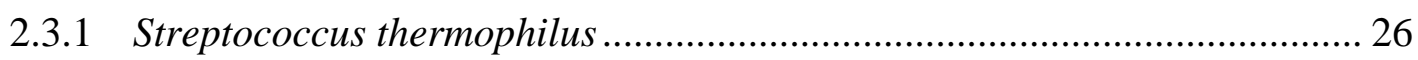

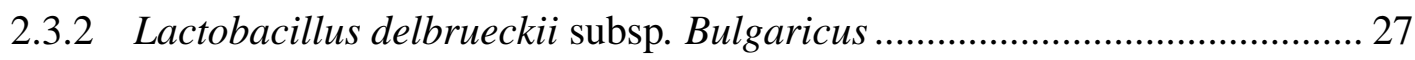


2.4 ROL DE LOS EXOPOLISACÁRIDOS PRODUCIDOS POR BACTERIAS ÁCIDO LÁCTICAS EN LA ELABORACIÓN DE QUESO. .............................. 28

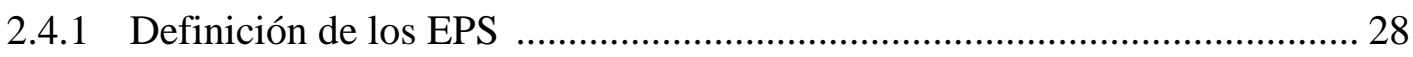

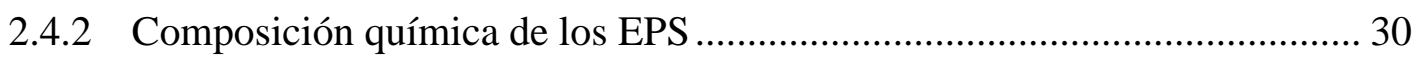

2.4.3 Factores que influyen en la producción de EPS por bacterias ácido

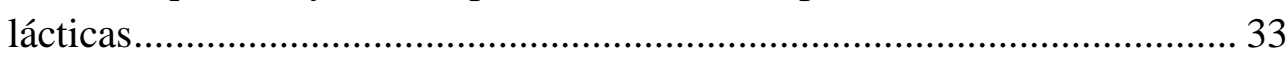

2.4.4 Aplicación de los exopolisacáridos producidos por bacterias ácido ........... 34

2.4.5 Efecto de los exopolisacáridos en la textura del queso................................. 35

2.4.6 La microscopía electrónica aplicada al estudio de los exopolisacáridos producidos por bacterias lácticas ................................................................ 37

2.4.7 Interacción entre los exopolisacáridos y la red de proteínas.......................... 38

2.5 EVALUACIÓN SENSORIAL DE QUESOS ...................................................39

2.5.1 Atributos a evaluar en el queso ................................................................ 41

2.5.2 Prueba Descriptiva de perfil de textura........................................................ 43

2.6 ANÁLISIS DE PERFIL DE TEXTURA (APT) ................................................ 45

\section{CAPÍTULO III. METODOLOGÍA: DISEÑO EXPERIMENTAL Y TÉCNICAS DE ANÁLISIS}

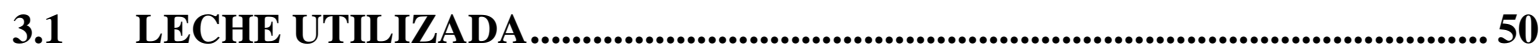

3.2 CULTIVOS INICIADORES .................................................................................... 50

3.3 MÉTODO DE ELABORACIÓN DE QUESO TIPO MANCHEGO.................51

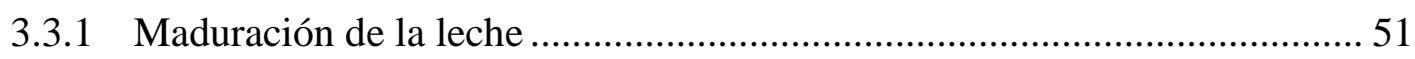

3.3.1.1 Viscosidad aparente ...................................................................... 51

3.3.1.2 Determinación de acidez total y $\mathrm{pH}$................................................... 51

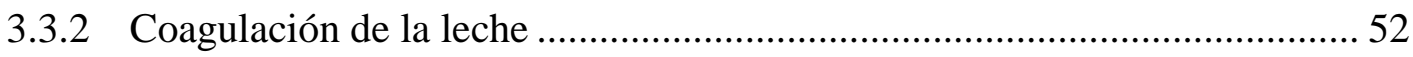

3.3.3 Cortado, cocimiento y desuerado de la cuajada ............................................. 52

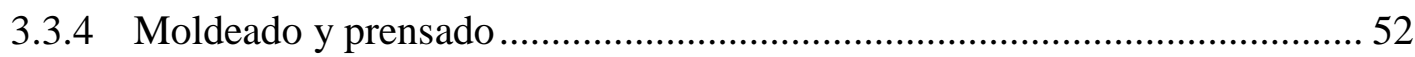

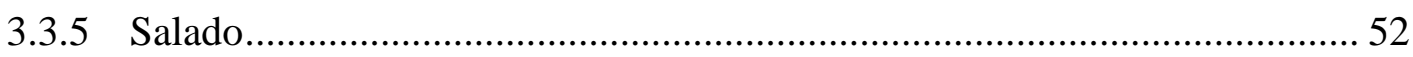

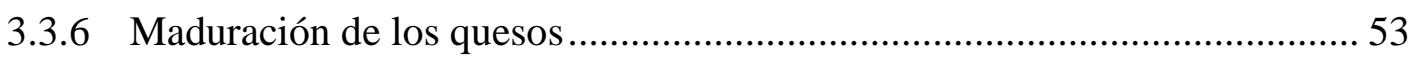

3.4 DETERMINACIÓN DEL RENDIMIENTO DE LOS QUESOS ......................53 
3.5 ANÁLISIS FISICOQUÍMICO DE LOS QUESOS ............................................... 53

3.5.1 Determinación de Sólidos Totales y Humedad.............................................. 53

3.5.2 Determinación de porcentaje de grasa, sólidos no grasos, grasa base seca y sólidos no grasos base seca ...................................................................... 54

3.5.3 Extracción y determinación de proteínas totales en queso ………………..... 54

3.6 MICROSCOPIA ELECTRÓNICA DE BARRIDO..............................................55

3.6.1 Preparación de la muestra ........................................................................... 55

3.6.2 Observaciones en el Microscopio Electrónico de Barrido Diferencial......... 56

3.7 ANÁLISIS DEL PERFIL DE TEXTURA (APT) ...........................................56

3.8 ANÁLISIS SENSORIAL DE TEXTURA ....................................................57

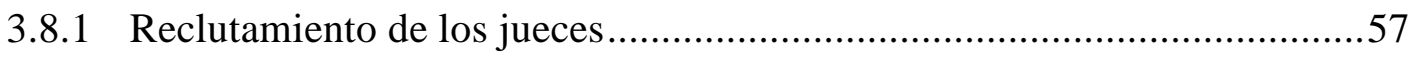

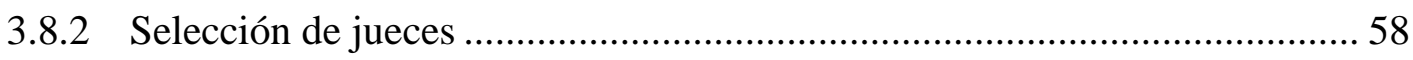

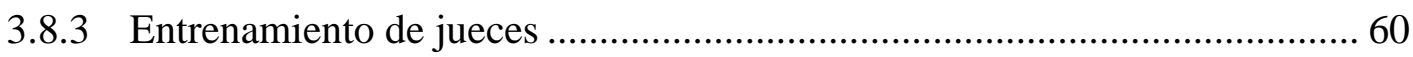

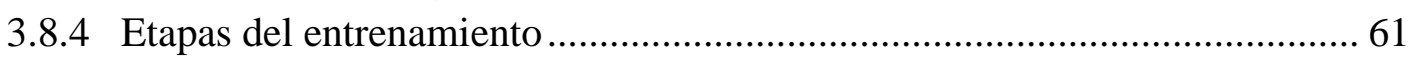

3.8.5 Pruebas Descriptivas Cuantitativas (Pruebas definitivas) ............................. 65

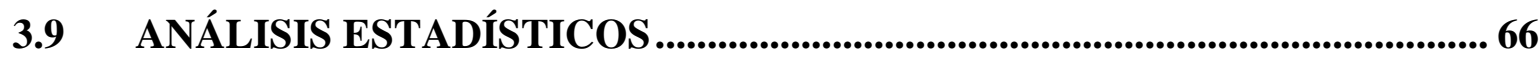

\section{CAPÍTULO IV. RESULTADOS Y DISCUSIÓN}

4.1 pH, ACIDEZ Y VISCOSIDAD APARENTE EN LA MADURACIÓN

DE LA LECHE ................................................................................................................... 68

4.2 COMPOSICIÓN FISICOQUÍMICA Y RENDIMIENTO

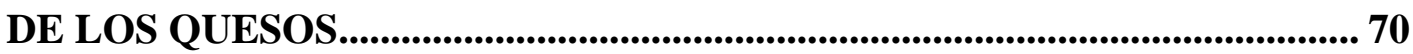

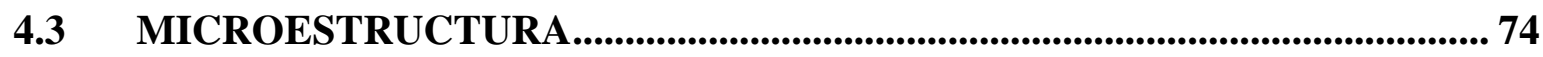

4.4 ANÁLISIS DEL PERFIL TEXTURA (APT) ................................................ 79

4.5 EVALUACIÓN SENSORIAL DE TEXTURA..................................................... 83

4.6 RELACIÓN ENTRE LAS PROPIEDADES FISICOQUÍMICAS Y LAS PROPIEDADES DE TEXTURA DEL QUESO MEDIANTE ANÁLISIS DE COMPONENTES PRINCIPALES ............................................. 84 
4.6.1 Relación entre el Análisis de Perfil de Textura y la composición

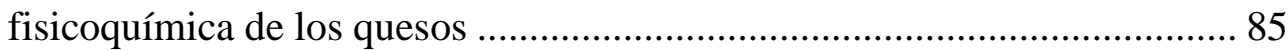

4.6.2 Relación entre la Evaluación Sensorial de textura y las propiedades fisicoquímicas de los quesos ............................................................... 88

\section{CAPÍTULO V. CONCLUSIONES}

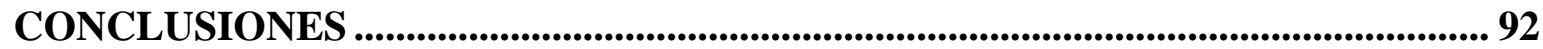

\section{CAPÍTULO VI. BIBLIOGRAFÍA}

BIBLIOGRAFÍA

\section{CAPÍTULO VII. ANEXOS}

Cuestionario 1. Encuesta de salud y hábitos alimenticios ....................................... 110

Cuestionario 2. Prueba de sensibilidad gustativa .................................................... 112

Cuestionario 3. Diferenciación entre niveles de Intensidad de estímulos ....................... 113

Cuestionario 4. Pruebas de diferenciación (Dúo-Trío)................................................. 114

Cuestionario 5. Pruebas de diferenciación (comparación por pares) ............................ 115

Cuestionario 6. Prueba de ordenación ........................................................................... 116

Cuestionario 7. Prueba descriptiva cuantitativa ....................................................... 117

Cuestionario 8. Prueba descriptiva cuantitativa (Prueba definitiva) ............................. 118 


\section{ÍNDICE DE TABLAS}

Tabla 1. Clasificación de los quesos según su contenido de humedad......................... 11

Tabla 2. Características fisicoquímicas de algunos quesos representativos

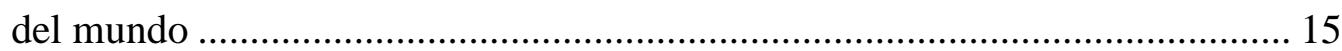

Tabla 3. Características fisicoquímicas de algunos quesos mexicanos ....................... 17

Tabla 4: Composición típica del queso manchego .................................................... 17

Tabla 5. Composición del queso tipo manchego .......................................................... 19

Tabla 6. Bacterias lácticas utilizadas en la elaboración de queso. .............................. 22

Tabla 7. Características generales de Streptococcus thermophilus .............................. 26

Tabla 8. Las características generales de Lactobacillus delbrueckii subsp.

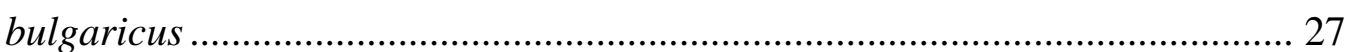

Tabla 9. Composición química y proporción de EPS producidos por algunas BAL. .... 32

Tabla 10. Tipos de fuerzas intermoleculares que contribuyen a las interacciones entre

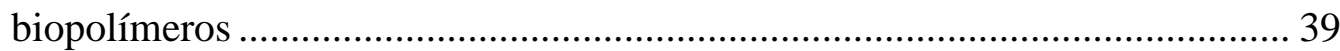

Tabla 11. Definición de descriptores obtenidos por los jueces................................... 42

Tabla 12. Soluciones de los cuatro sabores básicos................................................ 58

Tabla 13. Soluciones de diferentes concentraciones de sabores básicos ........................60 60

Tabla 14. Quesos comerciales utilizados en el entrenamiento de los jueces .................. 61

Tabla 15. Escalas de referencia utilizadas para el entrenamiento de los jueces ............. 63

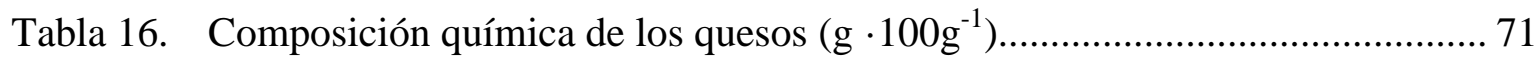

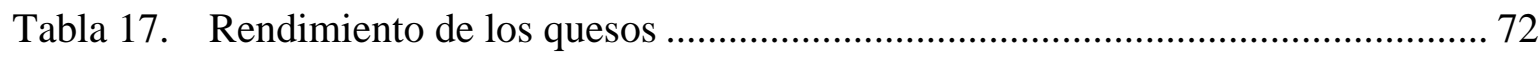

Tabla 18. Análisis del Perfil de Textura del Queso Control y el Queso Filante.............. 80

Tabla 19. ACP de la relación entre el APT y la composición fisicoquímica de los quesos

Tabla 20. Peso de los componentes del ACP de la relación entre el APT y la composición fisicoquímica de los quesos

Tabla 21. ACP de la relación entre el Análisis Sensorial de Textura y la composición fisicoquímica de los quesos 88

Tabla 22. Peso de los componentes del ACP de la relación entre el Análisis Sensorial de Textura y composición fisicoquímica de los quesos 88 


\section{ÍNDICE DE FIGURAS}

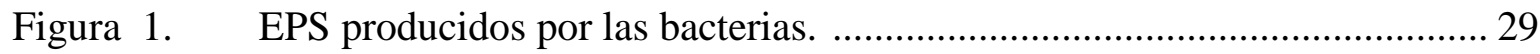

Figura 2. Micrografía de queso manchego elaborado con cepa filante obtenida

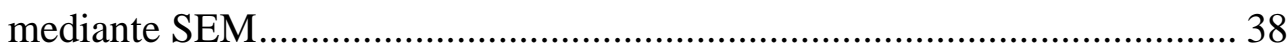

Figura 3 Sensaciones que se integran en el análisis sensorial de los quesos.............. 41

Figura 4. Curvas obtenidas del Análisis del Perfil de Textura ...................................... 48

Figura 5. Viscosidad aparente ( $\eta), \mathrm{pH}$ y acidez a lo largo de la

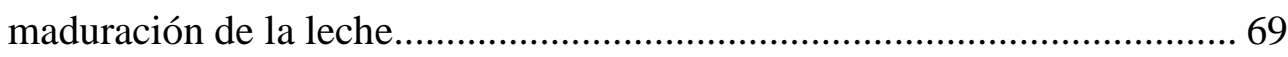

Figura 6. Variación de peso de los quesos durante la maduración................................. 74

Figura 7a. Microestructuras de la corteza del Queso Control (x 5000) ........................ 75

Figura 7b. Microestructuras de la parte media del Queso Control (x 5000) ................. 75

Figura 7c. Microestructuras del centro del Queso Control (x 5000)............................. 76

Figura 8a. Microestructuras de la corteza del Queso Filante (x 5000) …………….... 78

Figura 8b. Microestructuras de la parte media del Queso Filante (x 5000) ................ 78

Figura 8c. Microestructuras del centro del Queso Filante (x 5000) ............................. 79

Figura 9. Curvas obtenidas por el Análisis del Perfil de Textura para los quesos ....... 80

Figura 10. Comparación del perfil de textura sensorial de los quesos ......................... 184

Figura 11. Gráfica de análisis de componentes principales de textura instrumental y composición fisicoquímica del queso control y del queso filante .............. 87

Figura 12. Gráfica de análisis de componentes principales de textura sensorial y propiedades fisicoquímicas de Queso Control y Queso Filante 


\subsection{INTRODUCCIÓN}

Las bacterias ácido lácticas (BAL) productoras de exopolisacáridos (EPS) se han utilizado en la elaboración de algunos productos lácteos. La mayoría de los estudios en torno a este tipo de bacterias ha sido en yogurt, donde se ha demostrado que contribuyen a aumentar la viscosidad y/o disminuir la sinéresis (Wacher-Rodarte y cols., 1993). Estas características son útiles en la producción de otros productos lácteos, como queso.

Estudios realizados en queso Mozzarella han demostrado que el uso de cepas filantes produce cambios en la microestructura de cuajada, originando una red de proteínas más abierta, con tamaño de poros más grandes y una textura más suave, en comparación con un queso control sin la presencia de estas bacterias (Hassan y cols., 1997).

En adición existen informes de que el uso de cepas filantes de Streptococcus thermophilus en la elaboración de queso Mozzarella aumenta su contenido de humedad y mejora sus propiedades de fundido (Perry y cols., 1997; Low y cols., 1998 y Petersen y cols., 2000). Además del queso Mozzarella, se han utilizado cepas filantes en otros tipos de queso, como en el queso Feta (Hassan y cols., 2002) o en queso Panela, un queso fresco mexicano (Jiménez-Guzmán y cols., 2009). Los quesos Cheddar (Rynne y cols., 2007) y Karish (un queso egipcio de coagulación ácida) (Hassan y cols., 2004) reducidos en grasa y elaborados con una cepa no filante presentaron una estructura más compacta en comparación con aquella exhibida por los quesos que se elaboraron con cepas filantes.

Se ha demostrado asimismo que la cantidad de grasa determina características tales como el sabor y la textura del queso, sin embargo, no se ha estudiado todavía la influencia de los exopolisacáridos (EPS) en la retención de grasa, el rendimiento y las propiedades de textura del queso.

Alrededor del $20 \%$ del mercado de queso mexicano está constituido por quesos madurados, principalmente queso tipo Manchego y queso Chihuahua. Ambos son muy similares, ligeramente madurados, con una textura semi-dura y generalmente elaborados con una combinación de cultivos mesófilos y termófilos. El rendimiento que se obtiene para el queso madurado es más bajo que el observado en los quesos frescos, lo que los hace menos 
competitivos en el mercado mexicano. En este sentido, es importante aumentar el rendimiento de quesos madurados sin disminuir su sabor y su calidad para hacerlos económicamente más competitivos.

El objetivo del presente estudio fue determinar el efecto de Streptococcus thermophilus SY-102 productor de exopolisacáridos sobre la composición química, rendimiento y textura instrumental y sensorial de queso tipo Manchego.

Este estudio se basa en el análisis de tres aspectos del producto:

Composición físico-química y rendimiento.

Análisis de perfil de textura.

Evaluación sensorial de textura.

El aporte principal de esta tesis consistió en demostrar que las cepas productora de EPS pueden ser utilizadas en la elaboración del queso tipo manchego, para contribuir así al desarrollo de productos con características de textura y composición favorables con el fin de mejorar en los rendimientos de producción. 


\subsection{JUSTIFICACIÓN}

En algunos estudios realizados en quesos se ha observado que la utilización de bacterias ácido lácticas productoras de exopolisacáridos mejora la retención de agua y grasa, en consecuencia, aumenta su rendimiento. También se ha comprobado que esta retención de agua y grasa mejora la textura de quesos frescos debido a que los exopolisacáridos intervienen en la red que forman las proteínas generando un queso menos duro. Basados en esta información el presente estudio se avocó a explorar la posibilidad del uso de bacterias filantes en la elaboración de quesos semiduros como el queso tipo Manchego, buscando aumentar el rendimiento y obtener una mejor textura. 


\subsection{OBJETIVOS}

\section{Objetivo General}

El objetivo del presente estudio fue evaluar el efecto de Streptococcus thermophilus SY-102 -productor de exopolisacáridos- sobre la composición fisicoquímica, rendimiento, textura instrumental y sensorial de queso tipo Manchego.

\section{Objetivos particulares}

- Determinar por un método indirecto si la cepa de Streptococcus thermophilus SY102 produce EPS en la maduración de la leche destinada a la elaboración de queso tipo Manchego.

- Determinar cómo influyen los EPS producidos por Streptococcus thermophilus SY102 en la composición fisicoquímica y en el rendimiento del queso tipo Manchego.

- Realizar un estudio de Microscopía Electrónica de Barrido (SEM) en el centro, la parte media y la parte externa del queso, y observar si la presencia de EPS modifica la red de proteínas del queso.

- Determinar cómo influyen los cambios producidos en la composición físicoquímica debido a los EPS en la textura del queso. 


\subsection{HIPÓTESIS}

La utilización de una cepa de Streptococcus thermophilus productora de exopolisacáridos aumenta el rendimiento del queso tipo Manchego debido a que el EPS favorece la retención de agua y grasa. Estos cambios en las propiedades fisicoquímicas del queso pueden producir modificaciones en su textura, originando un queso menos duro y con una red de proteínas más abierta, en comparación con la que se produce en un queso elaborado con una cepa no filante. 


\section{CAPÍTULO II. ANTECEDENTES}




\subsection{GENERALIDADES DEL QUESO}

\subsubsection{Historia del queso}

No se sabe con exactitud dónde y cuándo apareció el queso. Lo más probable es que fue por accidente, ya que es producto de la acidificación natural de la leche. El queso quizás apareció en su forma más elaborada con coagulación enzimática, cuando el ser humano dejó de ser nómada y se hizo sedentario, criando animales y cultivando campos. En esta época prehistórica seguramente se empezaron a ordeñar las vacas y otros animales, así como a producir quesos (Cenzano, 1992).

Una antigua leyenda dice que el queso fue descubierto por un pastor nómada mientras realizaba un largo viaje por el desierto. Dicho pastor puso leche en un recipiente fabricado a partir del estómago de un cordero y cuando fue a consumirla vio que estaba coagulada y fermentada debido al cuajo del estómago del cordero y a las altas temperaturas del desierto. La leche se tornó sólida formando un producto agradable al paladar. Posteriormente, en vista de las ventajas obtenidas por el aumento de la vida útil del producto, se condimentó, se adoptó por las diferentes culturas y se difundió hasta llegar a ser uno de los productos lácteos predilectos en el mundo (Amiot, 1991).

La leche se conservaba en recipientes de piel, cerámica porosa o madera, pero como era difícil mantenerlos limpios, la leche fermentaba con rapidez. El siguiente paso fue extraer el suero de la cuajada para elaborar algún tipo de queso fresco, sin cuajo, de sabor fuerte y ácido.

Existen evidencias pictóricas que se remontan a 3,000 A.C. que revelan que los sumerios ordeñaban su ganado y transformaban la leche, y en Egipto se encontraron recipientes con indicios de leche cuajada. Existe evidencia de que se explotó la leche de varios mamíferos y de que se elaboró queso en otras culturas milenarias (Battistotti y cols., 1983). Además, se han descubierto indicios, en obras pictóricas y literarias clásicas, de que los griegos y los romanos conocían el "arte" de fabricar queso, llegando a ser un alimento común para la población (Villegas, 2003).

Los tipos de queso que predominaban posiblemente fueron los de pasta blanda, y los de 
pasta prensada con cierto grado de maduración. También se tienen indicios que existían algunos madurados por moho (Eckhof-Stark, 1983).

El nombre del producto en algunos idiomas proviene de la palabra griega formos, ya que así se llamaba el cesto para los quesos. De esta voz derivan el fromage en francés, fortmatge en catalán y el formaggio en italiano; en otros idiomas de la palabra latina caseus de donde proviene la palabra queso en español, cheese en inglés y caseína que es la principal proteína de la leche y del queso (Villegas, 2003).

El queso tuvo gran difusión en la época del Imperio Romano, en tanto que durante la Edad Media mostró tal aceptación que había monasterios dedicados a elaborar diferentes variedades de quesos con recetas que aún se conservan.

Con el auge del comercio y el aumento de la población urbana en el Viejo Mundo, el queso se convirtió en un producto importante para la economía y empezó a comercializarse fuera de las zonas de producción y más allá de las fronteras. Cuando se colonizó el Continente Americano se llevaron sus tradiciones queseras (Cenzano, 1992).

\section{Historia del queso en México}

En México y en el resto de América Latina, el queso se empezó a elaborar en el siglo XVI a la llegada de los españoles quienes introdujeron en el continente gran variedad de especies animales productoras de leche, como vacas, ovejas y cabras, a partir de las cuales obtenían leche para la elaboración de una amplia variedad de quesos (Cervantes y cols., 2008). Con la evangelización, llegaron a México monjes que se encargaron de enseñar a los indígenas los procesos para la elaboración del queso, y aunque seguían recetas típicas de Europa, el ingenio local dio pie a preparaciones dotadas de ese sello propio que tanto se disfruta en México y a nivel mundial (Villegas, 2003).

Pronto se empezaron a desarrollar zonas de fuerte actividad ganadera en México, como los Altos de Jalisco, actividad que desde antaño ha estado vinculada a la produccción de quesos. Pero también se han desarrollado varios tipos de quesos en regiones específicas como: el queso Oaxaca, Chihuahua, de morral, panela, adobera (Zacatecas), de rancho, Cotija, tipo Manchego y asadero, entre otros (Villegas, 2003). 


\subsubsection{Definición de queso}

La gran diversidad de quesos que existen en el mundo hace que sea difícil dar una definición general para el queso.

Una definición bastante aceptada es la que propone la FAO que establece lo siguiente: "El queso es el producto fresco o madurado, sólido o semisólido obtenido por:

a) Coagulación de la leche entera, leche descremada, leche parcialmente descremada, crema, crema de lactosuero, o suero de mantequilla, ya sea solo o en combinación, gracias a la acción del cuajo o de otros agentes coagulantes apropiados y por desuerado parcial del lactosuero resultante de esta coagulación, y/o

b) Por el empleo de técnicas de fabricación que implican la coagulación de la leche y/o de materia proveniente de ésta, a fin de obtener un producto terminado que posea las mismas características físicas, químicas y organolépticas que el producto definido en el inciso (a)" (Codex Alimentarius, OMS y FAO, 2007).

Como se puede apreciar en esta definición, se presenta una amplia cobertura y se pueden incluir los quesos elaborados por vía enzimática, ácida o mixta. También incluye los quesos fabricados con previa estandarización y además con leche en polvo o caseinatos.

En México, el queso está definido en la norma NOM-243-SSA1-2010, que dice lo siguiente: "Quesos: productos elaborados con la cuajada de leche estandarizada y pasteurizada de vaca o de otras especies animales, con o sin adición de crema, obtenida por la coagulación de la caseína con cuajo, gérmenes lácticos, enzimas apropiadas, ácidos orgánicos comestibles y con o sin tratamiento ulterior, por calentamiento, drenada, prensada o no, con o sin adición de fermentos de maduración, mohos especiales, sales fundentes e ingredientes comestibles opcionales, dando lugar a las diferentes variedades de quesos pudiendo por su proceso ser: fresco, madurado o procesado" (NOM-243-SSA1-2010).

Como podemos observar en esta definición, se incluyen también varios tipos de fermentación y abarca los diferentes tipos de quesos. 


\subsubsection{Clasificaciones de los quesos}

Existe una gran variedad de quesos y, es difícil establecer una clasificación de ellos. Las características que se pueden usar para agruparlos son múltiples y no siempre son comunes a todas las variedades (Keating y Gaona, 1986).

Se pueden utilizar criterios de clasificación tales como la leche con la que hayan sido elaborados, el tipo de pasta, la consistencia de la pasta, el grado de maduración, los agentes maduradores, la forma de coagulación, el contenido de materia grasa en la pasta, el contenido de humedad, etcétera. (Villegas, 2003).

Una de las clasificaciones más comunes y conocidas es según el contenido de humedad, lo cual influye en sus características de textura. El grado de maduración del queso determina también la cantidad de agua del mismo. La Tabla 1, presenta la clasificación de quesos según la humedad propuesta por Madrid (1999).

\section{Tabla 1. Clasificación de los quesos según su contenido de humedad}

\begin{tabular}{|l|c|}
\hline \multicolumn{1}{|c|}{ Tipo de queso } & \% Humedad \\
\hline Frescos & $60-80$ \\
Blandos & $40-60$ \\
Semiduros & $30-40$ \\
Duros & $20-40$ \\
\hline
\end{tabular}

Madrid (1999)

Los quesos frescos tienen alto porcentaje de humedad (del 60\% al $80 \%$ según variedades), generalmente no han sido madurados, su consistencia suele ser pastosa y su color blanco. Es por esto que tienen sabor a leche fresca o leche acidificada. Deben consumirse rápidamente, su transporte y conservación debe hacerse a temperaturas de refrigeración. Son quesos sin corteza, se prensan poco y, por lo tanto, se les elimina menos suero. Algunos ejemplos son: Cottage, Villalón, Burgos, Gervais, Panela, etcétera. (Hawthorn, 1983). 
Los quesos blandos tienen un contenido de humedad entre $40 \%$ y $60 \%$. Son quesos que pueden haber sido madurados durante algún tiempo (desde semanas hasta varios meses), desarrollando aromas y sabores característicos de cada tipo. Desarrollan corteza y la pasta es blanda e incluso semilíquida. La textura es cerrada aunque en algunos casos se toleran pequeños ojos. Los más conocidos son: el Camembert y el Brie. Por su alto contenido de humedad deben consumirse pronto, ya que al endurecerse pierden sus características más agradables (Madrid, 1999).

Los quesos semiduros son sometidos a maduración en periodos que fluctúan desde unas semanas hasta varios meses, con lo que parte de la humedad desaparece. Tienen de un $30 \%$ a $40 \%$ de agua, son de pasta dura, compacta, con o sin ojos, corteza más o menos dura, con o sin cortezas plásticas. Se pueden conservar durante largos periodos por tener menor cantidad de agua. Suelen ser quesos con aromas y sabores bastante desarrollados. Aquí se incluyen una serie de quesos muy diferentes entre sí, como son los de pasta azul como Roquefort, Gorgonzola, Danablu y Cabrales; los de pasta amarilla, cremosa y flexible como el Tilsit y Saint Paulin. Entre otros tenemos: Bel Paese, Manchego curado y Port Salut (Cenzano, 1992 y Hawthorn, 1983).

Los quesos duros son los que se han sometido a largos periodos de maduración, incluso superiores a un año, y han sido prensados con intensidad, por lo que su contenido de humedad se ha reducido fuertemente. Suelen tener de un $20 \%$ a un $40 \%$ de humedad, son de pasta dura, compacta, con o sin ojos, corteza más o menos dura, con o sin cortezas plásticas. Entre los quesos duros tenemos: Cheddar, Manchego Viejo, Gruyére, Emmental, Edam, Cantal francés, Roncal, etcétera. (Cenzano, 1992; Hawthorn, 1983).

\subsubsection{Composición fisicoquímica y valor nutritivo del queso}

El queso es un derivado lácteo fermentado que contiene muchos de los nutrientes originalmente presentes en la leche en forma concentrada. Sin embargo, una parte importante de las vitaminas hidrosolubles, algunos minerales y parte de la lactosa, se pierden en el proceso de desuerado, aunque los niveles finales de dichos componentes dependen de la síntesis y utilización de los microorganismos presentes. Se trata de productos ricos en 
nutrientes esenciales y en relación a su contenido energético, con un contenido bien equilibrado de grasa y proteína de alta calidad (De la Fuente y Juárez, 2001).

La concentración de nutrientes depende de una serie de factores como son: el tipo de leche utilizada como materia prima (vaca, oveja, cabra o mezcla de ellas), el proceso de elaboración y el tiempo de maduración, que afecta principalmente al contenido de humedad, y como consecuencia de ello, al valor calórico y al contenido de cada uno de los nutrientes (Tabla 2).

A continuación se explican cada uno de los macronutrientes del queso:

- La lactosa es el carbohidrato presente en la leche, es un disacárido constituido por glucosa y galactosa. Durante la elaboración de quesos y en la primera etapa de la maduración, la lactosa se transforma en ácido láctico por medio de las bacterias lácticas, provocando un descenso del $\mathrm{pH}$ que favorece la acción del cuajo, facilitando la separación del suero, previniendo así el desarrollo de microorganismos no deseables y regulando la proteólisis y la lipólisis. El suero arrastra casi toda la lactosa de la leche, por lo que su presencia en el queso es muy reducida (Madrid, 1999).

- La concentración de proteínas en el queso varía desde el 3\% (en quesos grasos para untar) hasta un $40 \%$, aunque en la mayoría de los casos la concentración se sitúa entre un $20 \%$ a $30 \%$. Entre las principales proteínas presentes en el queso está la caseína coagulable. La otra fracción, las proteínas no coagulables o proteínas del lactosuero, son las que no coagulan por acción del cuajo y de la acidez formando así parte de la composición del suero de quesería. La caseína puede ser desnaturalizada en el proceso de maduración (Madrid, 1999). En la maduración de los quesos se produce hidrólisis proteica por la acción de cuajo residual y por las proteasas microbianas dando lugar a péptidos y aminoácidos, siendo quizás el proceso más importante que afecta tanto a la textura como al sabor del producto. Este proceso hidrolítico sobre las proteínas favorece la digestibilidad del queso en relación a la leche de partida (Fox y cols., 1996). 
- Los contenidos de grasa en los quesos obtenidos a partir de leche entera oscilan entre $20 \%$ y $35 \%$ aunque en ocasiones se pueden obtener quesos con más de $40 \%$ de grasa. Además la grasa es responsable de la formación de algunas características del queso como la textura, el sabor, el aroma, el color y el rendimiento del queso. Representa el componente más abundante en los quesos; durante la maduración se hidroliza en gran parte, contribuyendo al desarrollo de aromas y sabores (Madrid, 1999).

- En cuanto a las sales minerales, su contenido oscila entre 1.2 y el $4.5 \%$, siendo las más importantes calcio, fósforo y hierro. Cuanto más fuerte es el proceso de fermentación láctica, la acidez es mayor y el contenido de sales minerales menor. Los quesos de pasta dura tienen un contenido de sales del $1.8 \%$ al $2 \%$, mientras que en los quesos azules, menos desuerados es de 3.5\% a $3.75 \%$ (Madrid, 1999).

- El queso es rico en vitaminas liposolubles (A, D y E). Su contenido depende de la cantidad de grasa del queso, la mayor parte de la vitamina A queda retenida en la cuajada. La mayor parte de las vitaminas hidrosolubles (vitamina $\mathrm{C}$ y vitaminas del complejo B) se pierden en el lactosuero. No obstante los niveles varían en función del tipo, variedad, proceso de elaboración y microorganismos presentes. Durante la maduración se modifican los contenidos de vitaminas del complejo B debido a la utilización o síntesis por parte de los microorganismos (Fox y cols., 1996).

- El agua que queda retenida en el queso desempeña un papel muy importante: es esencial para el desarrollo de los microorganismos y determina la velocidad de las fermentaciones y de los cambios producidos durante la maduración, el tiempo de conservación, la textura del queso y su rendimiento (Amiot, 1991).

La Tabla 2 muestra las principales características y la composición fisicoquímica de algunos quesos representativos del mundo. 
Tabla 2. Características fisicoquímicas de algunos quesos representativos del mundo

\begin{tabular}{|c|c|c|c|c|c|c|c|}
\hline $\begin{array}{l}\text { Tipo de } \\
\text { queso }\end{array}$ & $\begin{array}{c}\text { País de } \\
\text { origen }\end{array}$ & Tipo de pasta & $\begin{array}{l}\text { Maduración (* BAL: } \\
\text { Bacterias ácido lácticas) }\end{array}$ & $\begin{array}{l}\text { Humedad } \\
(\%)\end{array}$ & $\begin{array}{l}\text { Proteína } \\
(\%)\end{array}$ & $\begin{array}{c}\text { Grasa } \\
(\%)\end{array}$ & Fuente \\
\hline Asiago & Italia & Extra-Dura & Interna $(* \mathbf{B A L})$ & 41 & 26 & 31 & Cenzano, 1992 \\
\hline Blue & Dinamarca & Semidura & Interna (Mohos) & $38-50$ & $21-27$ & $25-36$ & Fox y cols., 2000 \\
\hline Brick & EUA & Semidura & Superficial (Bacterias) & 40 & 23 & 30 & Villegas, 2003 \\
\hline Brie & Francia & Blanda & Superficial (Mohos) & $46-55$ & $17-19$ & $21-27$ & Santos, 1991 \\
\hline Cabrales & España & Semidura & Interna (Mohos) & 42 & 22 & 33 & Santos, 1991 \\
\hline Camembert & Francia & Blanda & Superficial (Mohos) & $50-55$ & $17-21$ & $18-30$ & Fox y cols., 2003 \\
\hline Cheddar & Inglaterra & Dura & Interna (BAL) & $35-39$ & $25-28$ & $32-35$ & Fox y cols., 2003 \\
\hline Cottage & EUA & $\begin{array}{l}\text { Blanda (Coagu- } \\
\text { lación ácida) }\end{array}$ & No & $70-80$ & $15-25$ & $0.5-5.0$ & Fox y cols., 2003 \\
\hline Edam & Holanda & Semidura & \begin{tabular}{|l|}
$\begin{array}{l}\text { Interna con ojos } \\
\text { (metabolismo citrato) }\end{array}$ \\
\end{tabular} & $38-42$ & $26-28$ & $26-30$ & $\begin{array}{l}\text { Marcos y cols., 1993; } \\
\text { Fox y cols., 2003 } \\
\end{array}$ \\
\hline Emmental & $\begin{array}{l}\text { Suiza, } \\
\text { Francia }\end{array}$ & Dura & $\begin{array}{l}\begin{array}{l}\text { Interna (Bacterias } \\
\text { propiónicas) }\end{array} \\
\end{array}$ & $38-42$ & $28-30$ & $26-31$ & Fox y cols., 2003 \\
\hline Feta & $\begin{array}{l}\text { Israel, } \\
\text { Grecia } \\
\end{array}$ & Blanda & Interna (BAL) & $52-58$ & $18-21$ & $24-30$ & Fox y cols., 2003 \\
\hline Fontina & Italia & Semidura & Interna (BAL) & $41-43$ & $24-26$ & $24-27$ & $\begin{array}{l}\text { Fox y cols., } 2000 \\
\text { Botazzi, 1999 } \\
\end{array}$ \\
\hline Gluocester & Inglaterra & Dura & Interna (BAL) & 37 & 27 & 31 & Villegas, 2003 \\
\hline Gorgonzola & Italia & Semidura & Interna (Mohos) & $36-42$ & $20-26$ & $28-32$ & Fox y cols., 2000 \\
\hline Gouda & Holanda & Semidura & \begin{tabular}{|l|}
$\begin{array}{l}\text { Interna con ojos } \\
\text { (metabolismo citrato) }\end{array}$ \\
\end{tabular} & $38-42$ & $26-28$ & $26-30$ & Fox y cols., 2003 \\
\hline $\begin{array}{l}\text { Grana } \\
\text { Padano }\end{array}$ & Italia & Extra-Dura & Interna (BAL) & $30-32$ & $25-32$ & $28-36$ & $\begin{array}{l}\text { Villegas, } 1993 \\
\text { Cenzano, } 1992 \\
\end{array}$ \\
\hline Gruyere & Francia & Dura & $\begin{array}{l}\text { Interna (Bacte-rias } \\
\text { propiónicas) }\end{array}$ & $33-36$ & $28-30$ & $28-30$ & $\begin{array}{l}\text { Marcos y cols., 1993; } \\
\text { O'Connor y cols., 2000 }\end{array}$ \\
\hline Limburger & Bélgica & Blanda & Superficial (Bacterias) & 45 & 22 & 28 & Villegas, 2003 \\
\hline Manchego & España & Semidura & Interna (BAL) & $37-41$ & $23-28$ & $27-33$ & $\begin{array}{l}\text { Fox y cols., 2000; } \\
\text { O'Connor y cols., } 2000 \\
\end{array}$ \\
\hline Mozzarella & Italia & \begin{tabular}{|l|} 
Semidura \\
Filata
\end{tabular} & Interna (BAL) & $52-54$ & $18-22$ & $21-24$ & $\begin{array}{l}\text { Cenzano, 1992; Fox y } \\
\text { cols., 2000 }\end{array}$ \\
\hline Münster & Francia & Blanda & Superficial (Bacterias) & $41-43$ & $23-29$ & $23-30$ & Fox y cols., 2000 \\
\hline Neufchatel & Francia & Blanda & No & 62 & 12 & 21 & Villegas, 2003 \\
\hline $\begin{array}{l}\text { Parmigiano } \\
\text { Reggiano } \\
\end{array}$ & Italia & Extra-Dura & Interna (BAL) & $32-34$ & $32-36$ & $22-25$ & Fox y cols., 2003 \\
\hline Petit Suisse & $\begin{array}{l}\text { Suiza, } \\
\text { Francia } \\
\end{array}$ & Blanda & No & 55 & 7 & 35 & Villegas, 2003 \\
\hline Provolone & Italia & $\begin{array}{l}\text { Semidura } \\
\text { Filata }\end{array}$ & Interna (BAL) & $40-43$ & $25-27$ & $27-32$ & $\begin{array}{l}\text { Fox y cols., 2000; } \\
\text { Botazzi, } 1999\end{array}$ \\
\hline Ricotta & Italia & $\begin{array}{l}\text { Blanda (Coagu- } \\
\text { lación ácida) }\end{array}$ & No & 72 & 9 & 11 & $\begin{array}{l}\text { Fox y McSweeney, } \\
1998\end{array}$ \\
\hline Roquefort & Francia & Semidura & Interna (Mohos) & $40-42$ & $20-22$ & $30-33$ & $\begin{array}{l}\text { Santos, 1991; } \\
\text { Villegas, 2003 }\end{array}$ \\
\hline Stilton & Inglaterra & Semidura & Interna (Mohos) & 49 & 19 & 24 & Villegas, 2003 \\
\hline
\end{tabular}




\subsubsection{Composición fisicoquímica y características de algunos quesos mexicanos}

México cuenta con varios tipos de quesos, muchos de ellos se elaboran de forma artesanal, por lo que no tienen una calidad estándar. Su composición fisicoquímica puede variar (Espinosa y cols., 2006) y el consumidor encuentra que un mismo queso puede presentar características sensoriales y composición diferentes. Esta situación ha hecho dificil el establecimiento de normas de calidad. Existen normas para queso Chihuahua (NMX-F-209-1985), queso tipo Grùyere (NMX-F-184-1985), queso tipo Manchego (NMX- F-462-1984), queso tipo Suizo (NMX-F-470-1985), queso tipo Chester (NMX-F-471-1985). En el año 2011 el Consejo para el Fomento de la Calidad de la Leche y sus Derivados, A.C. (COFOCALEC), ha establecido normas para el queso Oaxaca (NMX-F-733-COFOCALEC-2010) y el queso Cotija (NMX-F735-COFOCALEC-2011). Esto ha sido de gran importancia para poder estandarizar la calidad de dichos quesos de gran consumo en México.

La bibliografía reporta diversos valores de composición fisicoquímica de algunos quesos mexicanos, debido a que la mayoría de los quesos son artesanales y muchos de ellos se elaboran todavía con leche cruda. En este sentido, la Revista del Consumidor, ha reportado varios estudios sobre la calidad de los quesos mexicanos donde se muestran estas variaciones (Revista del consumidor, 1990 y 2012). La Tabla 3 muestra algunos quesos más representativos de México y su composición. 
Tabla 3. Características fisicoquímica de algunos quesos mexicanos

\begin{tabular}{|l|c|c|c|c|c|l|}
\hline Queso & $\begin{array}{c}\text { Tipo de } \\
\text { pasta }\end{array}$ & Maduración & $\begin{array}{c}\text { humedad } \\
(\boldsymbol{\%})\end{array}$ & $\begin{array}{c}\text { Proteína } \\
(\mathbf{\%})\end{array}$ & $\begin{array}{c}\text { Grasa } \\
(\boldsymbol{\%})\end{array}$ & Fuente \\
\hline Adobera & Dura & No & 47 & 23.4 & 22.5 & Villegas, 2003 \\
\hline Asadero & $\begin{array}{c}\text { Dura } \\
\text { Hilada }\end{array}$ & No & $41-49$ & $21-30$ & $18-30$ & $\begin{array}{l}\text { De Alba y cols., } \\
1991, \text { Camacho, } \\
1983\end{array}$ \\
\hline Chihuahua & Dura & Sí & $33-38$ & $22-28$ & $27-36$ & Villegas, 2003 \\
\hline Cotija & $\begin{array}{c}\text { Extra-dura, } \\
\text { dura }\end{array}$ & Sí & $30-38$ & $26-29$ & $23-32$ & $\begin{array}{l}\text { Olivares y Villegas, } \\
1988\end{array}$ \\
\hline Fresco & Blanda & No & $44-57$ & $21-27$ & $17-21$ & $\begin{array}{l}\text { Hwang y } \\
\text { Gunasekaran, 2000 }\end{array}$ \\
\hline $\begin{array}{l}\text { Tipo } \\
\text { Manchego }\end{array}$ & $\begin{array}{c}\text { Dura, } \\
\text { Semidura }\end{array}$ & Si & $37-44$ & $21-25$ & $29-32$ & Villegas, 2003 \\
\hline Oaxaca & $\begin{array}{c}\text { Dura } \\
\text { Hilada }\end{array}$ & No & $40-51$ & $21-30$ & $29-30$ & $\begin{array}{l}\text { De Alba et al. 1991, } \\
\text { García-Islas, 2006 }\end{array}$ \\
\hline Panela & Blanda & No & $48-58$ & $20-23$ & $20-23$ & $\begin{array}{l}\text { Villegas, 2003, } \\
\text { Kosikowski, 2003 }\end{array}$ \\
\hline Ranchero & Blanda & No & $46-57$ & $17-21$ & $18-29$ & $\begin{array}{l}\text { Hwang y } \\
\text { Gunasekaran, 2001 }\end{array}$ \\
\hline
\end{tabular}

\subsubsection{El queso Manchego}

El queso Manchego es el queso Español por excelencia, elaborado exclusivamente con leche de oveja y con una maduración mínima de 60 días. En la actualidad está protegido por una Denominación de Origen, según se indica en las normas correspondientes, puede ser artesanal o industrial, según haya sido elaborado con leche cruda o con leche pasteurizada (Cenzano, 1991). La composición fisicoquímica del queso Manchego original se muestra en la Tabla 4.

Tabla 4: Composición típica del queso Manchego

\begin{tabular}{|l|l|}
\hline Composición & $\mathbf{( \% )}$ \\
\hline Humedad & $37-41$ \\
Proteína & $23-28$ \\
Materia grasa & $36-38$ \\
Sólidos totales & 55 (mínimo) \\
Cenizas & 3.6 \\
\hline
\end{tabular}

Fox y cols., (2000) 
Como norma general el queso Manchego presenta las siguientes características al final de la maduración:

- Forma: cilíndrica, con caras sensiblemente planas

- Altura: de 8 a $12 \mathrm{~cm}$

- Diámetro: de 18 a $22 \mathrm{~cm}$

- Peso: entre 2 y $3.5 \mathrm{~kg}$

- Corteza: dura, color amarillo pálido o verdoso-negruzco en el caso de que no se le limpie la superficie de los mohos desarrollados durante la maduración. La corteza debe presentar las impresiones de los moldes en la superficie lateral y de la "flor" en las caras planas.

- Pasta: firme y compacta, de color variable desde el blanco hasta el marfilamarillento, posibilidad de presentar ojos pequeños desigualmente repartidos. Aroma y sabor característico del queso Manchego (Madrid, 1999).

\subsubsection{Queso tipo Manchego}

El queso tipo Manchego, a diferencia del queso Manchego original, se elabora con leche de vaca y el tiempo de maduración es más corto, de 1 a 3 semanas, lo que hace un queso menos duro y con sabor menos intenso. Comparten semejanzas en la forma cilíndrico-plana, el peso entre 2 y $5 \mathrm{~kg}$ y el tipo de pasta (Villegas, 2003).

El queso tipo Manchego está tipificado, estandarizado y sujeto a normas técnicas oficiales (NMX- F-462-1984).

Debido a sus características, el queso tipo Manchego se clasifica como un queso de pasta prensada, semidura, firme y madurada, de color variable que va hasta el marfil amarillento. No suele presentar "ojos", sin embargo, en ocasiones los presenta muy pequeños y distribuidos de manera homogénea en todo el queso, con un sabor y olor característicos del queso tipo Manchego (Cervantes-Escoto, 2008). 
En la Tabla 5 se presenta la composición fisicoquímica del queso tipo Manchego.

Tabla 5. Composición del queso tipo Manchego

\begin{tabular}{|l|c|}
\hline Composición & $(\mathbf{\%})$ \\
\hline Humedad & 41.0 \\
Sólidos totales & 55.0 mínimo \\
Proteínas & 23.0 \\
Proteína en base seca & 30.0 mínimo \\
Grasa & 29.0 \\
Grasa base seca & 50.0 mínimo \\
Cenizas & 3.8 \\
Rendimiento & 8.9 \\
\hline
\end{tabular}

Santos (1991)

\subsubsection{Elaboración de queso tipo Manchego}

La elaboración de este producto consta de una tecnología que va más allá de las técnicas artesanales ya que se requiere emplear leche pasteurizada, manejar cultivos lácticos, aditivos (cloruro de calcio y nitrato de potasio), cortar el gel con liras, prensar la pasta homogénea y fuertemente y madurar el producto; por ello este tipo de queso es elaborado generalmente por empresas que cuentan con la infraestructura adecuada (Cervantes-Escoto, 2008).

Las etapas del proceso se detallan a continuación:

1. Pasteurización de la leche. La leche se pasteuriza a $75^{\circ} \mathrm{C}$ por $15-20$ segundos.

2. Maduración de la leche. La leche se calienta a $37^{\circ} \mathrm{C}$ con $2 \%$ con la mezcla de los cultivos (1.5\% de Lactococcus lactis subsp. lactis y Lactococcus lactis subsp. cremoris, más un $0.5 \%$ de Streptococcus thermophilus). La maduración de la leche se detiene cuando el $\mathrm{pH}$ alcanza un valor de 6.0. 
3. Coagulación de la leche. Una vez que la leche alcanza un $\mathrm{pH}$ de 6.0 se coagula con 1 $\mathrm{mL}$ de cuajo microbiano por litro de leche (fuerza del cuajo de 1:10000), y se incuba a $37^{\circ} \mathrm{C}$ por 30 a 45 minutos hasta obtener un gel firme.

4. Cortado, cocimiento y desuerado de la cuajada. Después de la coagulación, se corta la cuajada en cubos de aproximadamente $1 \mathrm{~cm}$ de arista y se mantiene en reposo por 15 min. Posteriormente, la temperatura se eleva lentamente $\left(1^{\circ} \mathrm{C} / \mathrm{min}\right)$ hasta alcanzar $45 \pm 2^{\circ} \mathrm{C}$, con agitación suave de la cuajada.

5. Cocido de la pasta. Cuando la temperatura alcanza los $45^{\circ} \mathrm{C}$, la cuajada se corta en piezas pequeñas y se deja drenar el $80 \%$ del suero, volteando las piezas ocasionalmente, hasta que el suero alcance una acidez titulable de 0.20-0.22\% de ácido láctico.

6. Moldeado y prensado. La cuajada se moldea en moldes de hierro forjado y se prensa por $24 \mathrm{~h}$ a presión constante de $1 \mathrm{~kg} \cdot \mathrm{cm}^{-2}$. Se realizan volteos a los $30 \mathrm{~min}, 1 \mathrm{~h}, 2 \mathrm{~h} \mathrm{y}$ luego cada $6 \mathrm{~h}$.

7. Salado. Después del prensado, los quesos se sumergen en salmuera al $10 \%$ de $\mathrm{NaCl}$ por $24 \mathrm{~h}$ a $10^{\circ} \mathrm{C}$ o bien puede hacerse por adición directa de sal a la cuajada.

8. Maduración de los quesos. Los quesos se sacan de los moldes y se mantienen a temperatura ambiente por $2 \mathrm{~h}\left(20^{\circ} \mathrm{C}\right.$ aproximadamente), luego se meten en una cámara de maduración $\left(10^{\circ} \mathrm{C}\right.$ a $12^{\circ} \mathrm{C}$, con una humedad relativa del $80 \%$ al $\left.90 \%\right)$ por 15 días. Cada 3 días se voltean y se limpian con una solución de sorbato de potasio al $0.2 \%$. 


\subsection{BACTERIAS ÁCIDO LÁCTICAS}

\subsubsection{Características generales de las bacterias ácido lácticas (BAL)}

Las bacterias lácticas se caracterizan por ser Gram positivas, no esporógenas, no motiles, no pigmentadas; de morfología variable como cocos, cocobacilos o bacilos que pueden disponerse también en filamentos o cadenas de más células. Son catalasa negativa, anaeróbicas facultativas, y para su desarrollo requieren carbohidratos fermentables, algunos aminoácidos, factores de crecimiento, vitaminas y sales minerales (Alais, 1991; Botazzi, 1999). Poseen proteasas ligadas a la pared celular que pueden hidrolizar parcialmente la caseína en péptidos asimilables que son degradados subsecuentemente por peptidasas de la membrana y el citoplasma. Las proteasas y peptidasas son liberadas por lisis celular al queso, lo que tiene una influencia directa sobre la formación del sabor. La actividad lipolítica es muy limitada (García-Garibay y cols., 1993).

Los géneros a los que pertenecen el grupo de bacterias lácticas son once, pero sólo cinco tienen interés en la industria de los lácteos: Lactococcus, Streptococcus, Lactobacillus, Leuconostoc y Pediococcus (Botazzi, 1999).

Las BAL se dividen en tres grupos en base al metabolismo de los azúcares:

a) Homofermentativas obligadas: metabolizan las hexosas casi exclusivamente a ácido láctico siguiendo la ruta Embdem-Meyerhof (ruta de hexosa difosfato). Entre éstas se encuentran algunas especies de Lactobacillus, Lactococcus y Streptococcus.

b) Heterofermentativas facultativas: metabolizan las hexosas casi exclusivamente a ácido láctico siguiendo la ruta Embdem-Meyerhof, pero en condiciones limitadas de glucosa producen ácido láctico, ácido acético, etanol y bióxido de carbono; pueden fermentar las pentosas con producción de ácido láctico y ácido acético (ruta de pentosa fosfato). Entre éstas están algunas especies de Lactobacillus.

c) Heterofermentativas obligadas: fermentan las hexosas con formación de ácido láctico, ácido acético, etanol y bióxido de carbono; las pentosas son fermentadas a ácido láctico y ácido acético (Botazzi, 1999). Cabe mencionar que este tipo de bacterias pueden producir 
compuestos aromáticos (carbonilos y alcoholes) importantes para el sabor de los quesos. Algunas especies de Lactobacillus, Pediococcus y Leuconostoc producen diacetilo y acetoína a partir de citrato en presencia de azúcares (García-Garibay y cols., 1993).

En la Tabla 6 se presentan algunas de las BAL usadas para la elaboración del queso con la descripción de sus características más importantes.

Tabla 6. Bacterias ácido lácticas utilizadas en la elaboración de queso.

\begin{tabular}{|c|c|}
\hline $\begin{array}{l}\text { Lactobacillus } \\
\text { Forma de bastoncito, crecen a } 4\end{array}$ & C pero no a $10^{\circ} \mathrm{C}$, no metabolizan el citrato. Son catalasa negativo. \\
\hline $\begin{array}{l}\text { Lactobacillus delbrueckii } \\
\text { subsp. bulgaricus }\end{array}$ & $\begin{array}{l}\text { No producen amoniaco a partir de la arginina; no fermentan la } \\
\text { galactosa. Generalmente se utilizan en la elaboración de yogurt y } \\
\text { quesos que se cocinan a altas temperaturas. }\end{array}$ \\
\hline $\begin{array}{l}\text { Lactobacillus delbrueckii } \\
\text { subsp. lactis }\end{array}$ & $\begin{array}{l}\text { Algunas cepas producen amoniaco a partir de la arginina; } \\
\text { fermentan la galactosa. Generalmente se utilizan en la elaboración } \\
\text { de yogurt y de quesos que se cocinan a altas temperaturas }\end{array}$ \\
\hline Lactobacillus helveticus & $\begin{array}{l}\text { No produce amoniaco a partir de la arginina; fermentan la } \\
\text { galactosa. Se utilizan en la elaboración de quesos madurados cuya } \\
\text { cuajada se cocina a altas temperaturas, en particular en el queso } \\
\text { grana y Emmental. }\end{array}$ \\
\hline $\begin{array}{l}\text { Lactococcus } \\
\text { Forma de coco de longitud } \\
\text { catalasa negativos, no móviles }\end{array}$ & $\begin{array}{l}\text { able, crecen a } 10^{\circ} \mathrm{C} \text { pero no a } 45^{\circ} \mathrm{C} \text {; fermentan la galactosa, son } \\
\text { hemolíticos. }\end{array}$ \\
\hline $\begin{array}{l}\text { Lactococcus lactis subsp. } \\
\text { cremoris }\end{array}$ & $\begin{array}{l}\text { No producen amoniaco a partir de la arginina ni crecen a } 40^{\circ} \mathrm{C} \text {; no } \\
\text { metaboliza el citrato. Se utilizan en la elaboración de quesos } \\
\text { cocinados a altas temperaturas. }\end{array}$ \\
\hline Lactococcus lactis subsp. lactis & $\begin{array}{l}\text { Producen amoniaco a partir de la arginina y crecen a } 40^{\circ} \mathrm{C} \text {; no } \\
\text { metabolizan el citrato. Se utilizan en la elaboración de quesos } \\
\text { cocinados a altas temperaturas. }\end{array}$ \\
\hline $\begin{array}{l}\text { Lactococcus lactis subsp. } \\
\text { lactis biovar diacetylactis }\end{array}$ & $\begin{array}{l}\text { Algunas cepas producen amoniaco a partir de la arginina y algunas } \\
\text { crecen a } 40^{\circ} \mathrm{C} \text {. Metabolizan el citrato del cual derivan compuestos } \\
\text { aromáticos como acetoína y diacetilo. Se utilizan en la elaboración } \\
\text { de algunos quesos y en la elaboración de mantequilla. }\end{array}$ \\
\hline $\begin{array}{l}\text { Leuconostoc mesenteroides } \mathbf{S} \\
\text { Son cocos; no producen amon } \\
\text { el citrato y fermentan la galact }\end{array}$ & $\begin{array}{l}\text { p. cremoris } \\
\text { a partir de la arginina; crecen a } 40^{\circ} \mathrm{C} \text { pero no a } 10^{\circ} \mathrm{C} \text {; metabolizan }\end{array}$ \\
\hline $\begin{array}{l}\text { Streptococcus thermophilus } \\
\text { Son cocos, representan como } \\
\text { partir de la arginina ni metab }\end{array}$ & $\begin{array}{l}\text { cocos, cadenas cortas o cadenas largas. No producen amoniaco a } \\
\text { el citrato; no fermentan la galactosa; crecen a } 45^{\circ} \mathrm{C} \text { pero no a } \\
\text { acáridos. Se utilizan en la elaboración de yogurt y queso. }\end{array}$ \\
\hline
\end{tabular}

Varnam y Sutherland, 1994 y Botazzi, 1999 


\subsubsection{Bioquímica de las bacterias ácido lácticas (BAL)}

\section{a) Metabolismo de la lactosa}

Las distintas bacterias que componen el cultivo iniciador tienen importantes diferencias en el metabolismo y transporte de la lactosa. En Lactococcus, el transporte a la célula es a través del sistema fosfotransferasa e implica la formación simultánea de lactosa-fosfato. La lactosafosfato es hidrolizada por la fosfo- $\beta$-galactosidasa a glucosa y a galactosa-6-fosfato que son metabolizadas por las vías glicolítica y tagatosa respectivamente.

En especies de Lactobacillus, Leuconostoc y en Streptococcus thermophilus, la lactosa entra intacta en la célula vía un sistema permeasa y es hidrolizada a continuación a glucosa y galactosa por una $\beta$-galactosidasa. La glucosa es metabolizada vía glicolítica en Lactobacillus y Streptococcus thermophilus; y en Leuconostoc ruta fosfocetolasa. La galactosa normalmente se metaboliza vía glucosa-1-fosfato por la ruta de Leloir. Las subespecies de Lactobacillus delbrueckii y la mayoría de las cepas de Streptococcus thermophilus son incapaces de metabolizar la galactosa, que es excretada (Varnam y Sutherland, 1994).

\section{b) Metabolismo proteico}

El contenido en aminoácidos libres de la leche es insuficiente para soportar el crecimiento extensivo de las bacterias lácticas, y el cultivo iniciador debe tener actividad proteinasa. Las proteinasas están situadas en la pared celular y son diferentes en número, localización y especificidad según las cepas. La actividad proteinasa produce una hidrólisis en las proteínas a oligopéptidos, que a su vez son hidrolizados a péptidos de bajo peso molecular y a aminoácidos por las aminopeptidasas asociadas a la pared celular. Las enzimas proteolíticas derivadas de los microorganismos del cultivo iniciador contribuyen también a la maduración del queso.

\section{c) Metabolismo del citrato}

Las únicas bacterias lácticas capaces de metabolizar el citrato son Lactococcus lactis subsp. lactis biovar. diacetylactis y las especies de Leuconostoc. Ésta es una propiedad muy importante, ya que los productos resultantes, como diacetilo y acetoína, son responsables del 
desarrollo del aroma en los quesos frescos y, en menor grado, también en los madurados. En los quesos holandeses, el $\mathrm{CO}_{2}$ producido en el metabolismo del citrato es el responsable de la formación de ojos característicos. La ruta metabólica básica vía piruvato es la misma para todas las bacterias que utilizan el citrato, el precursor en Lactococcus lactis subsp. lactis biovar dicetylactis es la acetil-CoA, mientras que en las especies de Leuconostoc puede intervenir el acetolactato (Varnam y Sutherland, 1994).

\subsubsection{Cultivos iniciadores para la elaboración de queso}

La microflora de la leche a temperatura ambiente produce ácido láctico; esta acidificación es el comienzo del proceso de elaboración de la mayoría de los quesos elaborados con leche cruda. Cuando se usa leche pasteurizada, gran parte de la microflora se destruye por el calor, por este motivo se agregan cultivos iniciadores acidificantes (BAL) para que se produzca el decremento del pH (Cogan, 2000).

El cultivo iniciador tiene el papel crucial de participar durante todas las fases del proceso de elaboración de queso y de su maduración. Cuando el cultivo crece en la leche, convierte la lactosa en ácido láctico para asegurar el pH correcto para la coagulación al momento de prensarlo, así como en el queso final madurado. Se pueden utilizar bacterias homofermentativas y heterofermentaivas para obtener ácido de láctico, etanol y $\mathrm{CO}_{2}$ como productos finales de la fermentación de los azúcares (Amiot, 1991).

Durante la maduración del queso, las enzimas proteolíticas y lipolíticas del cultivo ayudan a dar un aroma equilibrado ya que favorecen la producción de compuestos volátiles aromáticos, sabor, textura, apariencia de superficie requerida y la formación de ojos. Dada la importancia del efecto de los cultivos iniciadores en el carácter del producto final y en la economía de la producción, es esencial escoger el cultivo correcto, pero sobre todo, conocer las especificaciones de cada uno de ellos (Varnam y Sutherland, 1994). 


\section{Tipos de cultivos iniciadores}

Existen dos tipos de cultivos iniciadores dependiendo de la temperatura a la que crecen:

a) Cultivos iniciadores mesófilos

Las cepas principales de bacterias mesófilas son Lactococcus lactis subsp. lactis y Lactococcus lactis subsp. cremoris. Su temperatura de crecimiento oscila entre $10^{\circ} \mathrm{C}$ $42^{\circ} \mathrm{C}$. También se encuentra Lactococcus lactis subsp. lactis biovar. diacetylactis, que crece a una temperatura entre $25^{\circ} \mathrm{C}-30^{\circ} \mathrm{C}$ y es más sensible a la sal $(<4 \%)$ y a la temperatura $\left(<40^{\circ} \mathrm{C}\right)$. Se utilizan para la elaboración de quesos no madurados y madurados.

b) Cultivos iniciadores termófilos

Son bacterias cuya temperatura de crecimiento oscila de $20^{\circ} \mathrm{C}-54^{\circ} \mathrm{C}$. Su temperatura óptima de crecimiento es de $40^{\circ} \mathrm{C}-52^{\circ} \mathrm{C}$. Las cepas más utilizadas son: Streptococcus thermophilus, Lactobacillus delbrueckii subsp. bulgaricus y Lactobacillus helveticus (Holt y cols. 1994; Alais, 1991).

\subsection{BACTERIAS ÁCIDO LÁCTICAS PRODUCTORAS DE EXOPOLISACÁRIDOS (EPS)}

Las bacterias ácido lácticas (BAL), como ya dijimos, son un grupo de bacterias grampositivas, no formadoras de esporas y que producen ácido láctico como el producto más importante de la fermentación de carbohidratos. Muchas cepas BAL producen exopolisacáridos (EPS) los cuales son de gran interés en la elaboración de queso y yogurt (Cerning, 1995).

Algunas de las especies productoras de EPS más estudiadas son Lactococcus lactis, Streptococcus thermophilus y Lactobacillus delbrueckii subsp. bulgaricus. Las características más importantes de dichas bacterias se describen a continuación. 


\subsubsection{Streptococcus thermophilus}

Es una de las cepas más estudiadas por su producción de EPS. Su tiempo de replicación en leche es de 22 a 28 minutos y, en consecuencia, presenta una acidificación veloz.

Algunas cepas de Streptococcus thermophilus tienen la capacidad de producir polisacáridos. Con su desarrollo en leche, la cantidad de polisacáridos producidos varía según la cepa de 50 a $350 \mathrm{mg} / \mathrm{L}$, pero resulta mucho más alta cuando se asocian con otras cepas de Lactobacillus delbrueckii subsp. Bulgaricus, pues son también productoras de polisacáridos (producción que varía entre de 60 a 420 mg/L); en este caso se puede llegar a 800 mg/L de polisacáridos (Botazzi, 1999). En la Tabla 7 se muestran las características más importantes de esta bacteria.

Estas cepas son de interés en la elaboración de queso y yogurt porque se ha comprobado que los exopolisacáridos producidos por las mismas proporcionan a los geles proteínas características de textura deseables a los geles; además se ha observado que ayudan a retener agua y grasa en quesos (Jiménez-Guzmán y cols., 2009).

\section{Tabla 7. Características generales de Streptococcus thermophilus}

\begin{tabular}{|l|l|}
\hline Producción de ácido láctico a partir de: & lactosa, glucosa, manosa \\
Isómero de ácido láctico producido & $\mathrm{L}(+)$ \\
Cantidad de ácido láctico producido en leche & $<1 \%$ \\
Temperatura óptima de crecimiento & $42-48^{\circ} \mathrm{C}$ \\
Temperatura máxima de crecimiento & $52^{\circ} \mathrm{C}$ \\
Temperatura mínima de crecimiento & $19-21^{\circ} \mathrm{C}$ \\
Metabolismo & Homofermentativo \\
Hidrólisis de la lactosa por la intervención de & $\beta$-galactosidasa \\
Transporte de lactosa vía & Permeasas \\
Desarrollo en presencia de $2.5 \%$ de $\mathrm{NaCl}$ & Positivo \\
Desarrollo en presencia de $4 \%$ de $\mathrm{NaCl}$ & Negativo \\
$\mathrm{NH}_{3}$ y $\mathrm{CO}_{2}$ de urea & Positivo \\
\hline
\end{tabular}

(Botazzi, 1999) 


\subsubsection{Lactobacillus delbrueckii subsp. bulgaricus}

La especie de Lactobacillus delbrueckii subsp. bulgaricus son bacilos largos, aislados y en cortos filamentos; aparecen con frecuencia en forma de espiral alrededor de las colonias en los cultivos en el suero. La morfología es de largos filamentos de bacilos no diferenciados. Presenta un buen poder proteolítico por lo que tiene un rol muy importante para la maduración de los quesos (Botazzi, 1999).

La capacidad de producir polisacáridos es una propiedad tecnológica importante de estas bacterias, sobre todo porque la producción de polisacáridos garantiza una mayor viscosidad y una mejor paleatibilidad en la elaboración de yogurt. También condiciona la estructura y regula su rendimiento en peso. Esta bacteria se utiliza principalmente en yogurt, pero también en la elaboración de algunos quesos como el Mozzarella (Perry y cols, 1997).

Se incorpora con Streptococcus thermophilus y juntas forman los cultivos industriales para la producción de yogurt y algunos tipos de quesos.

En la Tabla 8 se muestran algunas de las características importantes de Lactobacillus delbrueckii subsp. bulgaricus.

Tabla 8. Las características generales de Lactobacillus delbrueckii subsp. bulgaricus

\begin{tabular}{|c|c|}
\hline Producción de ácido láctico a partir de: & Lactosa, glucosa y fructosa \\
\hline Tipo de ácido láctico producido & $\mathrm{D}(-)$ \\
\hline Cantidad de ácido láctico producido en leche & $>1.5 \%$ \\
\hline Temperatura óptima de crecimiento & $42-45^{\circ} \mathrm{C}$ \\
\hline Temperatura máxima de crecimiento & $48-52^{\circ} \mathrm{C}$ \\
\hline Metabolismo & Homofermentativo \\
\hline $\mathrm{NH}_{3}$ de arginina & Negativo \\
\hline $\mathrm{NH}_{3}$ y $\mathrm{CO}_{2}$ de urea & Negativo \\
\hline Hidrólisis de lactosas por la intervención de & $\beta$-galactosidasa \\
\hline Transporte de lactosa via & permeasa \\
\hline Producción de vitaminas & Ácido fólico, niacina, $\mathrm{B}_{6}, \mathrm{~B}_{12}$ \\
\hline
\end{tabular}

(Botazzi, 1999) 


\subsection{ROL DE LOS EXOPOLISACÁRIDOS PRODUCIDOS POR BACTERIAS ÁCIDO LÁCTICAS EN LA ELABORACIÓN DE QUESO.}

En los últimos años se han hecho diversas investigaciones sobre el rol de los EPS producidos por bacterias ácido lácticas, sobre todo en la elaboración de yogurt y de queso. Dichas investigaciones se han centrado primordialmente en la fisiología, la fermentación, las características químicas y estructurales de las moléculas de EPS, la biosíntesis, la genética y la ingeniería metabólica, así como en las propiedades funcionales de estas biomoléculas (RuasMadiedo y cols., 2005).

Los EPS se utilizan como aditivos alimentarios, aunque en los cultivos iniciadores de BAL pueden producirse in situ durante la fermentación de la leche. Por ello, se ha favorecido en la industria alimentaria el uso de cepas productoras de EPS como una fuente natural de espesantes de alimentos (Duboc y Mollet, 2001).

Además, se cree que algunos EPS producidos por BAL tienen efectos benéficos para la salud humana, tales como la capacidad para reducir el colesterol (Pigeon y cols., 2002), capacidad inmuno-moduladora, las actividades antitumorales (Kitazawa y col, 1998; Chabot y cols., 2001), además de efectos prebióticos (Dal Bello y cols., 2001; Korakli y cols., 2002). La mayoría de las bacterias ácido lácticas que producen EPS pertenecen a los géneros Streptococcus, Lactobacillus, Lactococcus, Leuconostoc y Pediococcus. También se ha demostrado que algunas cepas del género Bifidobacterium son capaces de producir estos biopolímeros (Abbad-Andaloussi y cols., 1995; Roberts y cols., 1995; Hosono y cols., 1997).

\subsubsection{Definición de los EPS}

El término exopolisacárido (EPS) se ha utilizado para referirse a cualquier tipo de polisacárido externo producido por bacterias (Sutherland, 1972). Los microorganismos que los producen se denominan cepas filantes ya que confieren viscosidad al medio de cultivo.

Los EPS se pueden localizar en la célula como parte de la membrana citoplasmática, ya sea a nivel de la pared celular o fuera de ella. Los polisacáridos que se localizan fuera de la pared celular se presentan en dos formas: como cápsulas adheridas a la superficie de las 
células por medio de enlaces covalentes o como material viscoso desprendido de la superficie de las bacterias que es excretado hacia el medio. Algunas cepas producen los dos tipos de EPS en diferentes proporciones (Zisu y Shah, 2005, 2007; Cerning, 1995; Wicken y cols. 1983). En la Figura 1 de muestran los dos tipos de EPS.

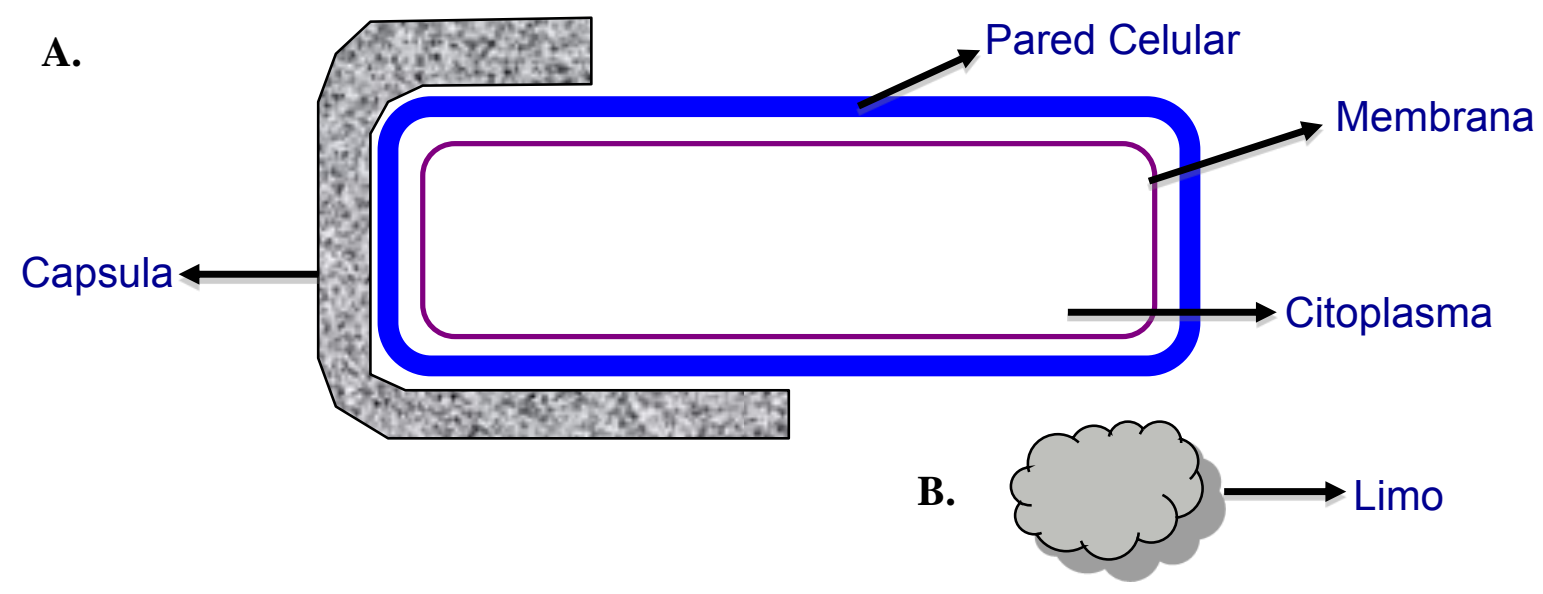

Figura 1. EPS producidos por las bacterias.

A) EPS pegados a la pared celular como cápsula; B) EPS excretados al medio como limo

La producción óptima de EPS se genera durante el máximo desarrollo de las células. En general, la producción de EPS inicia en la fase exponencial y puede alcanzar el máximo en la fase estacionaria (Petry y cols., 2000). En la última etapa de crecimiento, puede tener lugar la degradación de los EPS (Deegest de Vuyst, 2000; Pham y cols., 2000), probablemente debido a la activación de una enzima que degrada los EPS que tienen un peso molecular relativamente bajo de 50,000 a 10,000 Da. Se han encontrado endo y exo-enzimas en la descomposición de los EPS de bajo peso molecular, siendo aparentemente más dominante la actividad de las endo-enzimas (Degeest y cols., 2002b). 


\subsubsection{Composición química de los EPS}

La composición química de los EPS es variable, pues depende de muchos factores como el tipo de cepa y las condiciones de crecimiento. Dependiendo de su composición química, los EPS producidos por BAL se clasifican de dos formas:

a) Homopolisacáridos: son los que contienen un solo tipo de monosacárido, se compone de $\alpha$-glucosa y $\beta$-glucanos, mientras que los que contienen fructosa son los fructanos (levana). Estos tienen una estructura troncal con grados variables de ramificación; los sitios donde se unen dichas ramificaciones difieren entre las cepas bacterianas (Monsan y cols., 2001). Su tamaño puede ser mayor de 6 x $10^{6}$ Da (Cerning, 1990). Los homopolisacáridos extracelulares son producidos por algunas bacterias ácido lácticas tales como Leuconostoc mesenteroides y Streptococcus mutans (Sutherland, 1972; Cerning, 1990).

b) Heteropolisacáridos: son los que comprenden unidades de repetición de distintos monosacáridos (De Vuyst y cols., 2001). Las unidades de repetición de los heteropolisacáridos varían en número desde trisacáridos hasta octasacáridos y a menudo contienen una combinación de D-glucosa, D-galactosa, y L-rhamnosa y, en algunos casos, $\mathrm{N}$-acetilglucosamina, N-acetilgalactosamina, fucosa, ácido glucurónico y otros sustituyentes (fosfato, acetil, y glicerol) (Low y cols, 1998; Sikkema y Oba, 1998; De Vuyst y cols., 2001). La composición química, longitud de la cadena y la estructura de las subunidades, junto con la masa molar y el radio de giro de la molécula de EPS, determinan las características físicas y, por lo tanto, el grado de viscosidad que producen en leche (Marshall y cols., 2001a; Tuinier y cols., 2001; Ruas Madiedo y cols., 2002). Su tamaño varía desde $4 \times 10^{4}$ hasta $6 \times 10^{6}$ Da (Cerning, 1990). Los heteropolisacáridos extracelulares son producidos por especies de BAL, como Streptococcus thermophilus y Lactobacillus delbrueckii subsp. bulgaricus (Cerning, 1990; Sutherland, 1972). 
Los principales azúcares que componen los EPS son la glucosa y la galactosa (Degeest y cols., 2002; Marshall y cols., 2001a; Petry y cols., 2003) y, en menor cantidad, otros azúcares o sus derivados, tales como la ramnosa (Marshall y cols., 2001a; Petry y cols., 2003), $\mathrm{N}$-acetil glucosamina (Degeest y cols., 2002) o N-acetil galactosamina (Vaningelgem y cols., 2004). La galactosa es el monómero más común de muchos tipos de EPS secretados por Streptococcus thermophilus (Mozzi y cols., 2006; Vaningelgem y cols., 2004), en tanto que el menos común es la ramnosa (Mozzi y cols., 2006).

El rendimiento de EPS varía entre las cepas y se ve afectado por factores externos como la composición del medio y las condiciones de crecimiento (Degeest y cols., 2001a). Sin embargo, los monómeros de azúcar y su proporción tienden a permanecer sin cambios. La composición de los azúcares que componen los EPS es variable durante las primeras etapas de su formación, y se estabiliza en las etapas posteriores. En consecuencia, las diferencias de composición de los EPS entre las cepas disminuyen al final de la fermentación (Degeest y de Vuyst, 2000a; Mozzi y cols., 2006). Los homopolisacáridos se producen generalmente en cantidades mayores que los heteropolisacáridos (Cerning, 1995; Van Geel-Schutten y cols., 1999).

En la Tabla 9 se muestra la composición de los EPS de producidos por Streptococcus thermophilus y por Lactobacillus delbrueckii subsp. bulgaricus que se han reportado hasta ahora. 
Tabla 9. Composición química y proporción de EPS producidos por algunas BAL.

\begin{tabular}{|c|c|c|c|}
\hline Tipo de cepa & Composición polisacárido & Proporción & Referencia \\
\hline $\begin{array}{l}\text { Lactobacillus delbrueckii subsp. } \\
\text { bulgaricus }\end{array}$ & glucosa y fructosa & $1: 2$ & Cerning, 1990 \\
\hline $\begin{array}{l}\text { Lactobacillus delbrueckii subsp. } \\
\text { bulgaricus }\end{array}$ & galactosa-glucosa-ramnosa & $4: 1: 1$ & Sutherland, 1972 \\
\hline $\begin{array}{l}\text { Lactobacillus delbrueckii subsp. } \\
\text { bulgaricus CNRZ } 1187\end{array}$ & galactosa y glucosa & & Petry, 2000a \\
\hline $\begin{array}{l}\text { Lactobacillus delbrueckii subsp. } \\
\text { bulgaricus CNRZ } 416\end{array}$ & galactosa, glucosa y ramnosa & & Petry, 2000a \\
\hline $\begin{array}{l}\text { Lactobacillus delbrueckii subsp. } \\
\text { bulgaricus rr }\end{array}$ & $\begin{array}{l}\text { D-galactopiranosilo, D- } \\
\text { glucopiranosilo y L- } \\
\text { ramnopiranosilo }\end{array}$ & $5: 1: 1$ & Gruter y cols., 1993 \\
\hline Streptococcus thermophilus & galactosa y glucosa & $2: 1$ & $\begin{array}{l}\text { Cerning, 1990; } \\
\text { Sutherland, } 1972\end{array}$ \\
\hline Streptococcus thermophilus & $\begin{array}{l}\text { glucosa, galactosa y N- } \\
\text { acetilglucosamina }\end{array}$ & $2: 1: 1$ & Botazzi, 1999 \\
\hline Streptococcus thermophilus & $\begin{array}{l}\text { D-glucosa, D-galactosa y N- } \\
\text { acetil-D-glucosamina. }\end{array}$ & $1: 2: 1$ & Doco y cols., 1990 \\
\hline Streptococcus thermophilus & $\begin{array}{l}\text { D-galactosa, L-rhamnosa y } \\
\text { L-fucosa }\end{array}$ & $5: 2: 1$ & Doco y cols., 1990 \\
\hline Streptococcus thermophilus MR-1C & $\begin{array}{l}\text { Glucosa, galactosa y } \\
\text { ramnosa }\end{array}$ & $2: 3: 2$ & (Low y cols., 1998). \\
\hline $\begin{array}{l}\text { Streptococcus thermophilus } \\
\text { EU20 }\end{array}$ & D-glucosa y D-galactosa & $1: 1$ & $\begin{array}{l}\text { Marshal y cols. } \\
\text { 2001b }\end{array}$ \\
\hline Streptococcus thermophilus SFi39 & $\begin{array}{l}\text { D-galactosa, D- ramnosa y } \\
\text { D-glucosa }\end{array}$ & $3: 2: 1$ & $\begin{array}{l}\text { Lemoine y cols., } \\
1997\end{array}$ \\
\hline Streptococcus thermophilus SFi12 & D-galactosa y L-ramnosa & $2: 1$ & $\begin{array}{l}\text { Lemoine y cols., } \\
1997\end{array}$ \\
\hline Streptococcus thermophilus S3 & D-galactosa y L-ramnosa & $5: 2$ & Faber y cols., 2001 \\
\hline Streptococcus thermophilus Rs & D-galactosa y L-ramnosa & $5: 2$ & Faber y cols., 1998 \\
\hline Streptococcus thermophilus Sts & D-galactosa y L-ramnosa & $5: 2$ & Faber y cols., 1998 \\
\hline Streptococcus thermophilus OR 901 & $\begin{array}{l}\text { D-galactopiranosa y L- } \\
\text { ramnopiranosa }\end{array}$ & & Bubb y cols., 1997 \\
\hline
\end{tabular}




\subsubsection{Factores que influyen en la producción de EPS por bacterias ácido lácticas}

Algunos estudios reportaron que las condiciones de la fermentación (temperatura y tiempo de incubación), así como la producción de ácido láctico y la composición del medio de crecimiento (fuente de carbono y nitrógeno) afectan la producción del polímero y la composición del mismo (Cerning, 1995; Gancel y Novel, 1994a).

Ciertos experimentos demostraron que la naturaleza del azúcar, la temperatura y el pH inicial interfieren con la producción del polímero. En la tasa de crecimiento óptima, la producción del polisacárido es dependiente de la lactosa (Gancel y Novel, 1994a).

\section{Composición del medio de crecimiento, pH y temperatura}

Los EPS pueden ser sintetizados a partir de azúcares externos en el medio de crecimiento, o bien por los azúcares internos a través de la vía de Leloir (Boels y cols., 2001). Como consecuencia, la producción de EPS es variable y se puede alterar fácilmente por factores externos, por ejemplo, el tipo de azúcar, la temperatura y otros suplementos. En medios de crecimiento con lactosa Lactobacillus delbrueckii subsp. bulgaricus produce una concentración de EPS pobre, mientras que con la presencia de glucosa se obtienen concentraciones mayores (Petry y cols., 2000). Según Gancel y Novel (1994a), los medios de lactosa enriquecidos con glucosa incrementan la producción de EPS.

Petry y cols. (2000) reportaron que cuando se hizo crecer Streptococcus thermophilus en un medio de glucosa enriquecido con lactosa aumentó también la producción de EPS. Por lo tanto, la concentración de azúcar puede o no mejorar la producción de EPS y es dependiente del tipo de cepa (Petry y cols., 2000).

En algunas cepas, un exceso en la concentración de azúcares provoca una mayor producción de EPS, mientras que en otras cepas no se observó este comportamiento (Osman y cols., 1986).

Cuando se lleva a cabo la fermentación a un pH alrededor de 5.8 o 6.0 se incrementa la concentración de EPS en relación a valores de pH superiores (Kimmel y Roberts, 1998; Petry y cols., 2000; Dassy y cols., 1991; Hardy y cols., 1981). 
La temperatura también afecta la producción de EPS. Durante la fermentación en las cepas mesófilas se incrementa la producción del polímero a temperaturas bajas alrededor de $15-25^{\circ} \mathrm{C}$, mientras que en cepas termófilas se favorece a temperaturas más altas, alrededor de $42^{\circ} \mathrm{C}$ (De Vuyst y Degeest, 1999: Gancel y Novel, 1994a).

\section{Adición de otros nutrientes en el medio}

Algunos nutrientes como la tiamina, la adenina y la xantina (Petry y cols., 2000), así como las vitaminas del grupo B (Chervaux y cols., 2000) aumentan el crecimiento del microorganismo y, posteriormente, la producción de EPS.

El exceso de proteínas puede reducir el rendimiento de EPS (Kimmel y Roberts, 1998). Del mismo modo, las adición de suero de leche en baja concentración promueve la producción de EPS (Macedo y cols., 2002).

Se ha comprobado que la falta de oxígeno aumentó la producción de EPS (Petry y cols., 2000).

\subsubsection{Aplicación de los exopolisacáridos producidos por bacterias ácido lácticas}

Debido a la capacidad de los EPS de aumentar la viscosidad, o de actuar como agentes ligadores de agua en varios alimentos, estos polímeros pueden ser alternativas naturales a los estabilizadores comerciales (Cerning, 1990). Algunos estudios demuestran que el uso de BAL productoras de EPS en la fabricación del yogurt mejora la viscosidad y la textura del mismo por la disminución de la sinéresis (Wacher-Rodarte y cols., 1993; Kang y Cottrell, 1979; Van den Berg y cols., 1995).

El análisis de la microestructura en el queso Mozzarella ha demostrado que cuando la cuajada se calienta y se estira, la grasa y una porción grande del agua quedan situadas dentro de los canales formados la red de proteínas (McMahon y cols., 1993). Por otro lado, en el queso Mozzarella reducido en grasa se ha observado que hay muy pocos glóbulos de grasa que interrumpen la red de la proteína, dando por resultado menos espacio para la retención del agua (Oberg y cols., 1993); por consiguiente, el queso tiene una textura resistente y parecida a 
la de una goma y requiere más calor para derretir (Merrill y cols., 1994). Merrill y cols. (1994) demostraron que el uso de cepas productoras de EPS aumenta los niveles de humedad en quesos Mozzarella reducidos en grasa mejoran el cuerpo, la textura y las características funcionales (Merrill y cols., 1994). Además de esta funcionalidad mejorada, la capacidad de aumentar el nivel de la humedad en el queso (incluso tan pequeño como el 1\%) da a los productores una ventaja económica importante en una industria altamente competitiva (Low y cols., 1998).

Las temperaturas de pasteurización elevadas, la pre-acidificación de la leche, el corte grande de cuajada y las bajas temperaturas de cocido ayudaron a aumentar la retención de la humedad del queso Mozzarella reducido en grasa. Los sustitutos de grasa en queso Mozzarella han sido eficaces en la retención de la humedad (Merril y cols., 1994); sin embargo, las características de fundido y de estiramiento no son las deseadas (McMahon y cols., 1993). Jiménez-Guzmán y cols. (2009) han demostrado la capacidad que tienen los EPS para ligar agua y aumentar el rendimiento en queso panela (Jiménez-Guzmán y cols., 2009).

Perry y cols. (1997) demostraron que las cepas productoras de EPS se podían utilizar como alternativa para producir quesos bajos en grasas sin sustitutos de las mismas (Perry y cols., 1997).

Aunque la capacidad de incrementar el rendimiento de los quesos debido la retención de agua es un incentivo para la utilización de bacterias productoras de EPS, su uso puede ser limitado por el hecho de que los EPS provocan el aumento en la viscosidad del suero y, en consecuencia, retardan los procesos de concentración y secado, así como la modificación de las características funcionales de los mismos (Marshall y cols., 1995; Masters y cols. 1995) (Petersen y cols., 2000).

\subsubsection{Efecto de los exopolisacáridos en la textura del queso}

Se han realizado estudios sobre cómo se modifica la textura de los quesos con el uso de BAL productoras de EPS, demostrándose que un mayor contenido de grasa y de agua en los quesos tienden a debilitar la estructura de proteínas, produciendo un queso más suave (Jack y cols., 1992; Tunick y cols., 1993a, 1993b). 
Según Chen y cols. (1979) y Emmons y cols. (1980) los quesos que contienen mayor contenido de grasa resultan ser quesos más suaves y más masticables. Por otra parte, los datos reportados por Bryant y cols. (1995), a partir de una investigación hecha con queso Cheddar con diferentes contenidos de grasa, establecieron que la microestructura de los quesos bajos en grasa presenta una matriz de proteínas más compacta y con menos espacios abiertos. Esto está asociado a una mayor dureza, incluso aunque el contenido de humedad fuera más alto. Estos autores también reportan que la compleja microestructura abierta de los quesos analizados por microscopía electrónica de barrido (SEM) se perdió debido a una disminución en el contenido de grasa (Chen y cols., 1979; Emmons y cols., 1980; Bryant y cols., 1995.

Lobato-Calleros y cols. (2001) observaron que la reducción de grasa en el queso mexicano tipo Manchego produjo un queso más duro al no tener las interrupciones propias de los glóbulos de grasa y, por lo tanto, se observan zonas más densas y compactas en la matriz de proteínas. Por otra parte, es bien sabido que el aumento del contenido de humedad en los quesos provoca un producto menos duro que los de humedad más baja (Tunick, 1991; Jack y cols., 1992).

Domínguez-Soberanes y cols. (2001) sugirieron que las interacciones entre los EPS y las caseínas de la leche fermentada aumentaron la cohesividad. En un producto sólido: la propiedad de cohesividad representa qué tanto su estructura resiste la deformación y/o el desgarro, por lo que una mayor cohesividad en el queso filante sugiere que hay una fuerte interacción entre los EPS y las caseínas de la matriz de proteínas del queso.

Con relación a la elasticidad, Bryant y cols. (1995) reportaron que en el queso Cheddar la elasticidad aumentó con la disminución del contenido de grasa. Esto concuerda con Emmons y cols. (1980), que establecieron que el queso reducido en grasa tiende a ser más elástico.

Está claro que la relación entre la composición del queso y su perfil de textura es muy compleja, y que existen otros factores que también influyen en la textura del producto, como son las condiciones del proceso y la microbiota. Esto hace que sea difícil establecer una relación directa entre los componentes del queso y su perfil de la textura, como lo reportaron Van Hekken y cols. (2007) y Tunick y cols. (2007) en el queso Chihuahua, que es similar a la textura del queso tipo Manchego. (Van Hekken y cols., 2007; Tunick y cols., 2007). 


\subsubsection{La microscopía electrónica aplicada al estudio de los exopolisacáridos producidos por bacterias ácido lácticas}

En los últimos 50 años la microscopia electrónica se ha extendido con aplicaciones en diversos campos científicos, particularmente en medicina y en el ámbito físico y químico. Actualmente el uso de la microscopía electrónica abarca desde la investigación puramente científica hasta las aplicaciones de control de proceso en la industria (Duchesne y Daniel, 1999).

Algunos estudios han probado que la microscopía electrónica de barrido (SEM) es una de las técnicas más adecuadas para la observación de la microestructura de productos alimenticios y consituye una herramienta útil para la observación de exopolisacáridos producidos por bacterias en quesos (Kalab, 1979).

La observación de los EPS mediante microscopia electrónica es difícil debido a su alto contenido de agua y a las sustancias presentes en la fijación, en la deshidratación y en el proceso de tinción (Bayer, 1994). Se recomienda la observación microscópica de montajes húmedos para determinar la presencia de cápsulas bacterianas (Murray y cols., 1994).

Las observaciones microscópicas directas han sido un útil y simple acercamiento para obtener información de la función de los EPS en los productos lácteos. La SEM fue utilizada extensivamente para observar leches fermentadas por cultivos productores de EPS (Kaláb y cols., 1993; Schellhaassand y cols., 1985; Teggetz y Morris, 1990). Con la SEM, los EPS aparecen como filamentos asociados a las células de las bacterias y a la red de las proteínas. La apariencia de los EPS en las microestructuras presenta una apariencia filamentosa debido a que su estructura se colapsa durante la deshidratación aplicada a la muestra antes de su observación.

Hay otras técnicas de observación directa de exopolisacáridos, como la desarrollada por Hassan y cols. (1995), quienes utilizaron microscopía láser confocal de exploración (CSLM por sus siglas en inglés), la cual permite la observación de células bacterianas hidratadas y vivas. Usando pruebas fluorescentes no tóxicas y análisis de imágenes con computadora, la CSLM permite visualizar microorganismos dentro de su medio de crecimiento y dentro de su microambiente fisicoquímico (Hassan y cols., 1995). Sin embargo, 
la dificultad de esta técnica está en el tipo de instrumento que se utiliza, ya que no se encuentra disponible en cualquier centro de investigación.

En la Figura 2 se muestra una micrografía, de queso tipo Manchego elaborado con una cepa productora de EPS. Como se puede observar en la micrografía los EPS se muestran como filamentos blancos y largos.

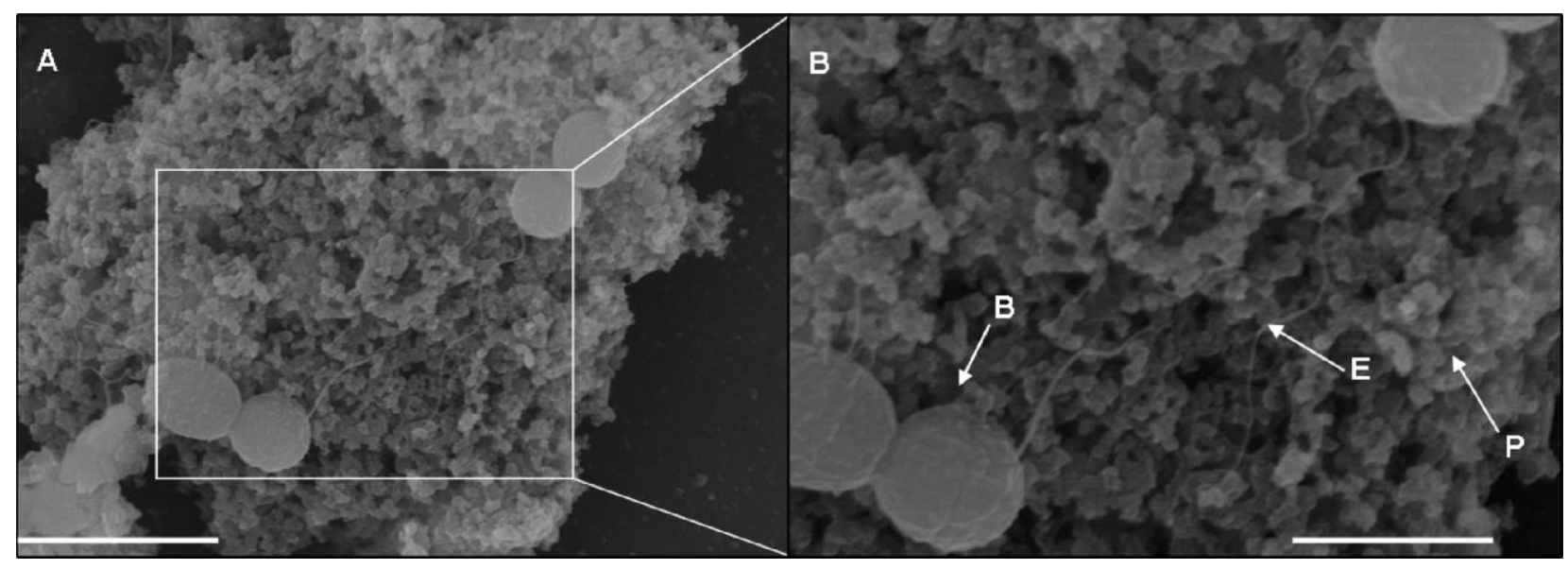

Figura 2. Micrografía de queso Manchego elaborado con cepa filante obtenida mediante SEM. E-EPS, P-Proteínas y B-Bacterias (Ayala-Hernández y cols., 2008)

\subsubsection{Interacción entre los polisacáridos y la red de proteínas}

Según las condiciones del medio, las proteínas se comportarán de manera diferente ante los diversos tratamientos, por ejemplo, durante la adición de sales o la mezcla con otros biopolímeros. Todos estos comportamientos se producen por diferentes interacciones entre moléculas proteicas o interacciones otros biopolímeros, como proteínas y polisacáridos.

Las interacciones entre estos biopolímeros involucran diferentes tipos de fuerzas intermoleculares, mismas que se describen en la Tabla 10.

La importancia relativa de estas interacciones en un sistema particular depende del tipo de biopolímero involucrado (peso molecular, densidad de carga en función del pH, flexibilidad, hidrofobicidad), las características de la solución ( $\mathrm{pH}$, fuerza iónica) y las condiciones ambientales (temperatura, cizalla) (McClemensts y cols., 2006; Pilosof y cols., 2010). 
Tabla 10. Tipos de fuerzas intermoleculares que contribuyen a las interacciones entre biopolímeros

\begin{tabular}{|l|l|}
\hline Covalentes & $\begin{array}{l}\text { Unión muy fuerte formada entre grupos reactivos específicos de diferentes } \\
\text { macromoléculas. Ejemplo: uniones por puentes disulfuro }\end{array}$ \\
\hline Electrostáticas & $\begin{array}{l}\text { Interacción que puede ser repulsiva o atractiva según el signo de las cargas } \\
\text { eléctricas. La fuerza de estas interacciones disminuye con el aumento de la } \\
\text { fuerza iónica }\end{array}$ \\
\hline $\begin{array}{l}\text { Volúmenes de } \\
\text { exclusión }\end{array}$ & $\begin{array}{l}\text { Es una interacción repulsiva dada por el gran volumen ocupado por algunos } \\
\text { biopolímeros en solución, produce un importante efecto sobre la exclusión } \\
\text { estérica }\end{array}$ \\
\hline Uniones de hidrógeno & $\begin{array}{l}\text { Interacción atractiva moderadamente fuerte entre átomos de hidrógeno y otros } \\
\text { átomos mucho más electronegativos. Las uniones por puentes de hidrógeno se } \\
\text { debilitan cuando aumenta la temperatura }\end{array}$ \\
\hline Hidrofóbicas & $\begin{array}{l}\text { Interacción atractiva moderadamente fuerte de origen entrópico entre grupos } \\
\text { no polares. Las uniones hidrofóbicas aumentan su fuerza con el aumento de la } \\
\text { temperatura }\end{array}$ \\
\hline Puentes iónicos & $\begin{array}{l}\text { Tipo específico de interacción que involucra la unión de cationes polivalentes } \\
\text { (específicamente Ca }{ }^{2+} \text { ) con dos grupos aniónicos diferentes }\end{array}$ \\
\hline $\begin{array}{l}\text { Fuerzas de Van Der } \\
\text { Waals }\end{array}$ & $\begin{array}{l}\text { Interacción atractiva débil de origen electromagnético entre grupos con } \\
\text { dipolos inducidos o permanentes }\end{array}$ \\
\hline
\end{tabular}

Dickinson (1998); McClements (2006).

\subsection{EVALUACIÓN SENSORIAL DE LOS QUESOS}

La apreciación de los alimentos se produce fundamentalmente a través de la percepción sensorial así como mediante las modernas tecnologías. A pesar de disponer de procedimientos de analítica instrumental, los científicos son más conscientes de la necesidad de potenciar los métodos analíticos basados en dicha apreciación sensorial que, en definitiva, son los más adecuados para la valoración final de la calidad de los alimentos (León y Galán, 1991). El análisis de los componentes químicos y de las propiedades físicas de un alimento aporta información sobre la naturaleza del estímulo que percibe el consumidor, pero no sobre la sensación que éste experimenta al ingerirlo (Costell y Durán, 1981).

La evaluación sensorial es un auxiliar de suma importancia para el control y mejora de la calidad de los alimentos, ya que a diferencia del análisis físico-químico o microbiológico, 
que solo dan una información parcial acerca de alguna de sus propiedades, dicha evaluación permite hacerse una idea global del producto de forma rápida al proveer da información de un aspecto de importancia capital: su grado de aceptación o rechazo.

Se considera que el aparato sensorial humano muestra grados de variación de sensibilidad de persona a persona, ya que cada mundo individual de sensaciones es muy diferente dependiendo del nivel de desarrollo, además de que la sensibilidad puede ser influenciada fácilmente por circunstancias externas o del medio (Jellinek, 1985). Uno de los mayores problemas asociados a la evaluación sensorial de los alimentos es conseguir que la respuesta humana sea precisa y reproducible. El control de las condiciones, tanto del entorno y de las muestras a analizar, como de los sujetos participantes en las pruebas sensoriales, facilitará la obtención de unos resultados objetivos. Actualmente, se han reunido los métodos y protocolos para el desarrollo del análisis sensorial en las correspondientes normas ISO (ISO 8586-1:1993(E)). Es importante destacar que para valorar un alimento correctamente es necesario conocer bien las características del mismo.

El queso, junto con el vino, es uno de los alimentos que están más difundidos en las tradiciones gastronómicas mundiales, y como tales han sido objeto de numerosos estudios, tanto técnicos como hedónicos y nutricionales; pero curiosamente, puede constatarse que hay pocos estudios de caracterización sensorial sobre los aromas de los quesos, cuya complejidad, sobre todo, en los quesos de leche cruda afinados largos meses en cavas de maduración, sólo es comparable a la de los vinos de crianza.

Algunos grupos de expertos correspondientes a los Consejos de Denominación de Origen de algunos tipos de quesos más importantes de Europa han elaborado guías para la evaluación sensorial de quesos de pasta dura o semidura, que en líneas generales pueden ser de aplicación a otros quesos. En la primera de estas guías se hace especial hincapié en los aspectos de textura (Lavanchy y cols., 1994), en tanto que en la segunda se insiste más en los aspectos olfato-gustativos (Bérodier et al., 1996), siempre referidos a los quesos de pasta dura o semidura (Sancho y cols., 2002). 


\subsubsection{Atributos a evaluar en el queso}

Los atributos sensoriales son las propiedades de los alimentos que se detectan por medio de los sentidos, y se pueden separar en tres grupos no netamente diferenciados: los de apariencia, los de sensaciones cinestésicas (textura) y los de sabor (Figura 3).

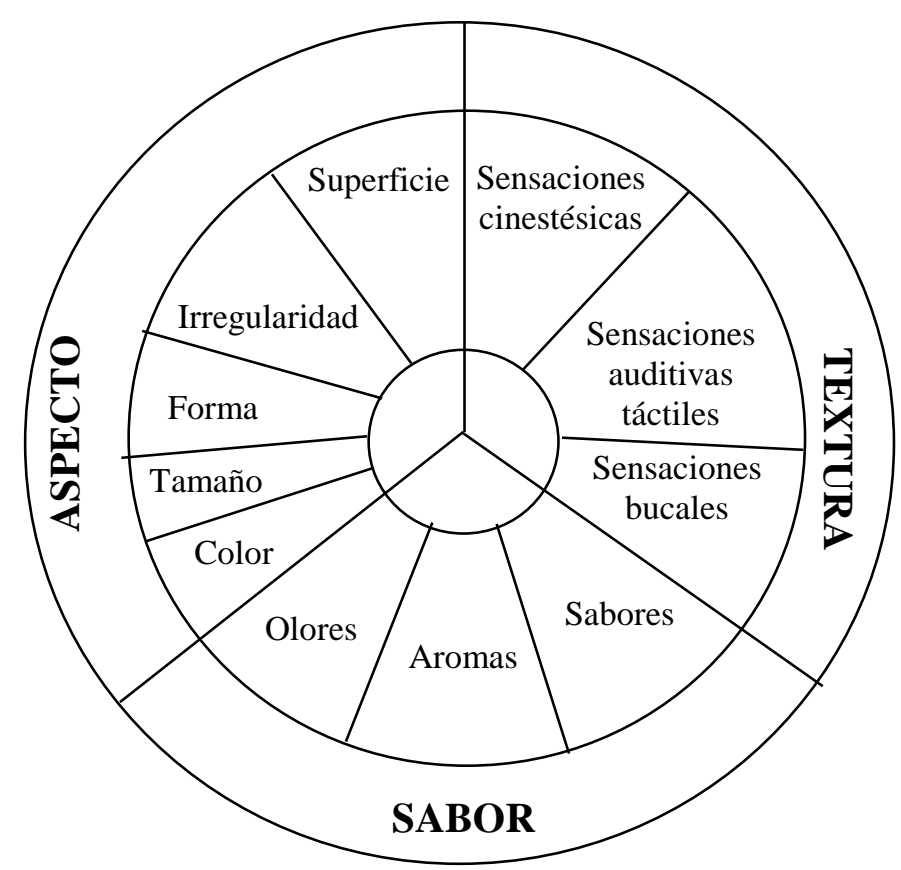

Figura 3. Sensaciones que se integran en el análisis sensorial de los quesos

Lavanchy y cols. (1993)

\section{Consistencia/textura}

La textura es la propiedad sensorial de los alimentos que se detecta mediante los sentidos del tacto, la vista y el oído, y que se manifiesta cuando el alimento sufre una deformación (Anzaldúa-Morales, 1994). También se puede definir a la textura como el conjunto de propiedades mecánicas, geométricas y de superficie de un producto, perceptibles por los receptores mecánicos, táctiles y, en ciertos casos, los visuales y los auditivos (Norma ISO 11036:1994E). La Tabla 11 presenta las definiciones de algunas propiedades de textura, tanto mecánicas como geométricas. 
Tabla 11. Definición de descriptores obtenidas por los jueces

\section{CARACTERÍSTICAS MECÁNICAS PRIMARIAS}

PROPIEDADES

DUREZA

COHESIVIDAD

VISCOSIDAD

ELASTICIDAD

ADHESIVIDAD

\section{Física}

Fuerza necesaria para una producir una deformación dada.

Medida de qué tanto puede deformarse un material antes de romperse.

Propiedad que tiene un líquido a fluir cuando se aplica una fuerza externa.

Proporción en la que un material deformado regresa a su condición inicial después de cesar la fuerza deformante.

Trabajo necesario para vencer las fuerzas de atracción entre la superficie del alimento y la superficie de los otros materiales con los que el alimento entra en contacto.

\section{DEFINICIONES}

\section{Sensorial}

Fuerza requerida para comprimir una sustancia entre las muelas (sólidos) o entre la lengua y el paladar (semisólidos).

Grado hasta el cual se comprime una sustancia entre los dientes antes de romperse.

Fuerza requerida para pasar un líquido de una cuchara hacia la lengua.

Grado hasta el cual regresa un producto a su forma original una vez que ha sido comprimido entre los dientes.

Fuerza requerida para retirar el material que se adhiere a la boca (generalmente al paladar) durante la masticación.

\section{CARACTERÍSTICAS MECÁNICAS SECUNDARIAS}

PROPIEDADES

FRACTURABILIDAD

MASTICABILIDAD

GOMOSIDAD

\section{Física}

Fuerza con la cual se fractura un material. Está relacionada con los parámetros de dureza y cohesividad.

Energía requerida para masticar un alimento hasta que esté listo para ser deglutido (como una combinación de dureza, cohesividad y elasticidad).

Energía requerida para desintegrar un alimento semisólido a un estado listo para deglutirlo (como una combinación de alta adhesividad y baja dureza).

\section{DEFINICIONES}

\section{Sensorial}

Fuerza con la que un material se desmorona, cruje o se estrella.

Tiempo requerido para masticar la muestra, a una tasa constante de aplicación, para reducirla a una consistencia adecuada para tragarla.

Densidad que persiste a lo largo de la masticación; energía requerida para desintegrar un alimento semisólido a un estado adecuado para tragarlo.

Anzaldúa-Morales, (1994). 


\subsubsection{Prueba descriptiva de perfil de textura}

La prueba descriptiva del perfil de textura es el análisis sensorial de la complejidad de la textura de un alimento en términos de sus características mecánicas, geométricas y de la intensidad de su presencia, así como el orden en el cual éstos se presentan desde la primera mordida y a través de la masticación, hasta deglutir el producto. La prueba de perfil de textura, basada en la prueba de perfil de sabor, comprende los siguientes parámetros:

\section{Descriptores}

Es la terminología que genera un grupo de jueces para definir y describir la sensación percibida a partir de las características de la textura, y se enlistan a continuación:

a) Características mecánicas: relativas a la reacción del alimento ante un esfuerzo aplicado al mismo. Se subdivide en los siguientes parámetros:

- Primarios: dureza, cohesividad, viscosidad, adhesividad.

- Secundarios: quebradizo, correoso, gomoso.

b) Características geométricas: relativas a la percepción de la forma de un alimento. Se subdivide en dos parámetros:

- Aquéllas relacionadas con el tamaño y la forma de las partículas, como arenoso o granuloso

- Aquéllas relacionadas con la forma y orientación, tal como fibroso u hojueloso.

c) Otras características: relativas a la sensación que provoca la presencia de la humedad, no solo como cantidad de agua presente en el alimento, sino también en relación con la velocidad de absorción o liberación de humedad. En cuanto a la presencia de lípidos, es importante la cantidad y tipo de aceite y grasa. 


\section{Intensidad}

Es el grado en el cual se percibe una característica y se suscribe dentro de un continuo predeterminado: por ejemplo, usando una escala estructurada como una línea recta de $10 \mathrm{~cm}$ de largo: (Pedrero, 1989).

Ejemplo:

Poco intenso Muy intenso

Dureza

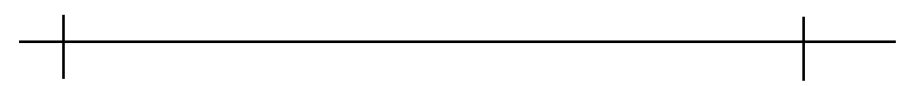

\section{Muestras}

Esta técnica requiere de escalas de referencia para ejemplificar cada parámetro mecánico y geométrico. Dicha escala debe de estar compuesta de varios productos (no necesariamente comestibles) que definan cada grado de intensidad del atributo; el producto que forme parte de la escala debe poseer aquella característica y grado de intensidad en particular que se vaya a evaluar como su propiedad sobresaliente.

Szczesniak y cols. (1963) han elaborado algunas escalas de referencia, pero pueden ser modificadas para adaptarlas a los productos disponibles en la localidad, e incluso al rango de variabilidad dentro del cual se espera que oscile la muestra problema, como lo han reportado Bourne (1976) y Anzaldúa Morales y Vernon (1982).

\section{Jueces}

El entrenamiento de los jueces es un requerimiento indispensable, ya que la clara comprensión técnica, las escalas y el material en estudio garantiza la precisión de los resultados (Pedrero, 1989).

Los jueces deben tener, de preferencia, su dentadura completa, sin caries, ya que la presencia de éstas - o las amalgamas, prótesis y otros medios para corregirlas- afectan la percepción de la textura (Anzaldúa-Morales, 1982). Asimismo es importante que la alineación de los dientes y las mandíbulas sea normal. Los defectos tales como el prognatismo pueden redundar en la percepción inadecuada de las características de textura del alimento. 
Una de las pruebas preliminares para la selección y entrenamiento de los jueces consistirá en proporcionar a los candidatos una serie de productos, en un orden aleatorio, y pedirles que describan las propiedades de textura que perciben. Se le asignan puntuaciones a las respuestas y, en general, se seleccionan a los candidatos que obtienen como mínimo el 65\% del total de puntos posibles. También se pueden presentar diferentes muestras de composición y características controladas y pedir a los sujetos que las clasifiquen en orden creciente en intensidad respecto a un determinado atributo (Ibáñez y Barcina, 2001).

\subsection{ANÁLISIS DE PERFIL DE TEXTURA (APT)}

Ya que la textura se manifiesta como resultado de haber sometido el alimento a un esfuerzo deformante, el estudio mecánico del alimento puede proporcionar alguna información acerca de sus atributos de textura (Mohsenin, 1970).

La medición instrumental de la textura fue propuesta como una alternativa a la evaluación sensorial con el fin de superar los principales inconvenientes y limitaciones de esta última en cuanto a la gran variabilidad que puede existir en los resultados, la dificultad de ejecución de las pruebas y la interpretación de resultados.

Por ello, es necesario que las medidas obtenidas con métodos instrumentales puedan correlacionarse con respuestas de jueces analíticos de la evaluación sensorial para que de esta forma el uso de una técnica instrumental sea válido y confiable. Se han desarrollado diversos métodos instrumentales basados en el estudio del comportamiento mecánico de los alimentos (Mohesein, 1970).

Las propiedades mecánicas se analizan sometiendo el producto a una fuerza, ya sea de compresión, corte, punción o extrusión, y observando la deformación producida por el esfuerzo correspondiente.

Existen una gran variedad de métodos instrumentales de medición de textura, pero todos ellos se basan en los siguientes elementos (Voisey, 1975):
a) una punta de prueba (aplicación de un esfuerzo),
b) una fuente de movimiento,
c) un elemento registrador. 
En general los métodos instrumentales se pueden clasificar en tres tipos:

1. Métodos fundamentales: son aquellos en los que se trata de definir lo más exactamente posible el comportamiento reológico del alimento, establecer las ecuaciones que rigen dicho comportamiento y medir los parámetros y coeficientes involucrados en dichas ecuaciones (Brennan, 1980). La correlación entre los parámetros obtenidos en este tipo de pruebas y los resultados de evaluación sensorial realizada al mismo producto no es muy alta, ya que se trata de dos propiedades con niveles muy diferentes de variabilidad de los datos numéricos, sin embargo, su aplicaron en desarrollo de formulaciones es muy precisa y conlleva ventajas muy superiores a otros métodos de investigación (Sherman, 1975).

2. Métodos empíricos. Son los más utilizados. En este método se aplica un esfuerzo de cualquier tipo al alimento, ya sea de compresión, corte, punción, extrusión, flexión, tensión, etcétera, y se mide la respuesta del alimento, por ejemplo, su disminución o aumento de longitud, el tiempo que tarda en recuperar su forma o tamaño original después de la deformación y la fuerza requerida para la ruptura, entre otros. Esto se hace de una forma totalmente empírica. Uno de los instrumentos más usados es la Máquina Probadora Universal Instron, con la cual es posible llevar a cabo la técnica conocida como Análisis Instrumental del Perfil de Textura. Además del insturmento citado, se cuenta con aparatos empíricos como los consistómetros, los penetrómetros y los viscosímetros. Otro ejemplo de un aparato para medir la textura es el Medidor "PAM".

3. Instrumentos imitativos. En estos instrumentos se trata de simular la acción de los dedos, la mano, los dientes o incluso la boca al deformar un alimento para determinar su textura. Los hay muy sencillos como el "diente" para medir textura de espagueti y otras pastas, hasta otros más complejos.

Una de las máquinas más modernas para la medición de textura de alimentos aplicable a todas las pruebas es el Analizador de Textura TA-XT2. Este aparato fue diseñado especialmente para alimentos, tiene controles electrónicos muy precisos, su sensibilidad es muy alta y es muy versátil. Tiene un programa de computadora que recoge los datos y las gráficas y los guarda automáticamente, eliminando la necesidad de un graficador. 
No hay que olvidar que estos instrumentos son sólo un auxiliar de la evaluación sensorial y no pueden sustituir al ser humano.

Del texturómetro TA.XT2i (Stable Micro Systems, Texture Technologies Corp., White Plains, NY) se obtienen curvas como las que se muestran en la Figura 4, a partir de las cuyo análisis se puede determinar si la muestra tiene los atributos de textura deseados.

En la Figura 4 se observa que la fuerza aumenta hasta que ocurre un rompimiento del tejido, marcado por una disminución en la fuerza. La altura de este pico representa la Fragilidad $\left(\mathbf{f}_{1}\right)$. El rompimiento del tejido continúa con un incremento de fuerza al desparramarse la muestra, hasta que termina el recorrido y comienza el retorno. La máxima altura de esta parte de la curva es la Dureza $\left(\mathbf{f}_{2}\right)$. Con el retorno, la fuerza disminuye rápidamente a cero y aparece una fuerza de tensión originada por la Adhesividad $\left(\mathbf{A}_{\mathbf{3}}\right)$, hasta que la placa superior logra desprenderse de la muestra y la fuerza llega nuevamente a cero. A partir de este punto comienza el segundo ciclo. La primera sección transcurre con fuerza cero porque el producto no se recupera totalmente; cuando la placa entra en contacto por segunda vez con el alimento, la fuerza se eleva de nuevo en una curva continua hasta que el recorrido se completa y comienza de nuevo el retorno. La recuperación entre el primero y el segundo ciclo es una medida de la Elasticidad (longitud 2/ longitud 1). La Cohesividad es la relación de las áreas de trabajo efectuado en el segundo y en el primer ciclo por la máquina (Cohesividad $\left.=\mathbf{A}_{2} / \mathbf{A}_{1}\right)$. La Gomosidad es igual a la Dureza por la Cohesividad, y es una función de fuerza (Gomosidad $\left.=\left(\mathbf{f}_{2}\right) \mathbf{A}_{2} / \mathbf{A}_{1}\right)$. La Masticabilidad es igual a la Dureza por la Cohesividad por la Elasticidad y es una función de trabajo (Masticabilidad $=\left(\mathbf{f}_{2}\right)\left(\mathbf{A}_{2} / \mathbf{A}_{1}\right)$ (Elasticidad) (Szczesniak y cols., 1963). 


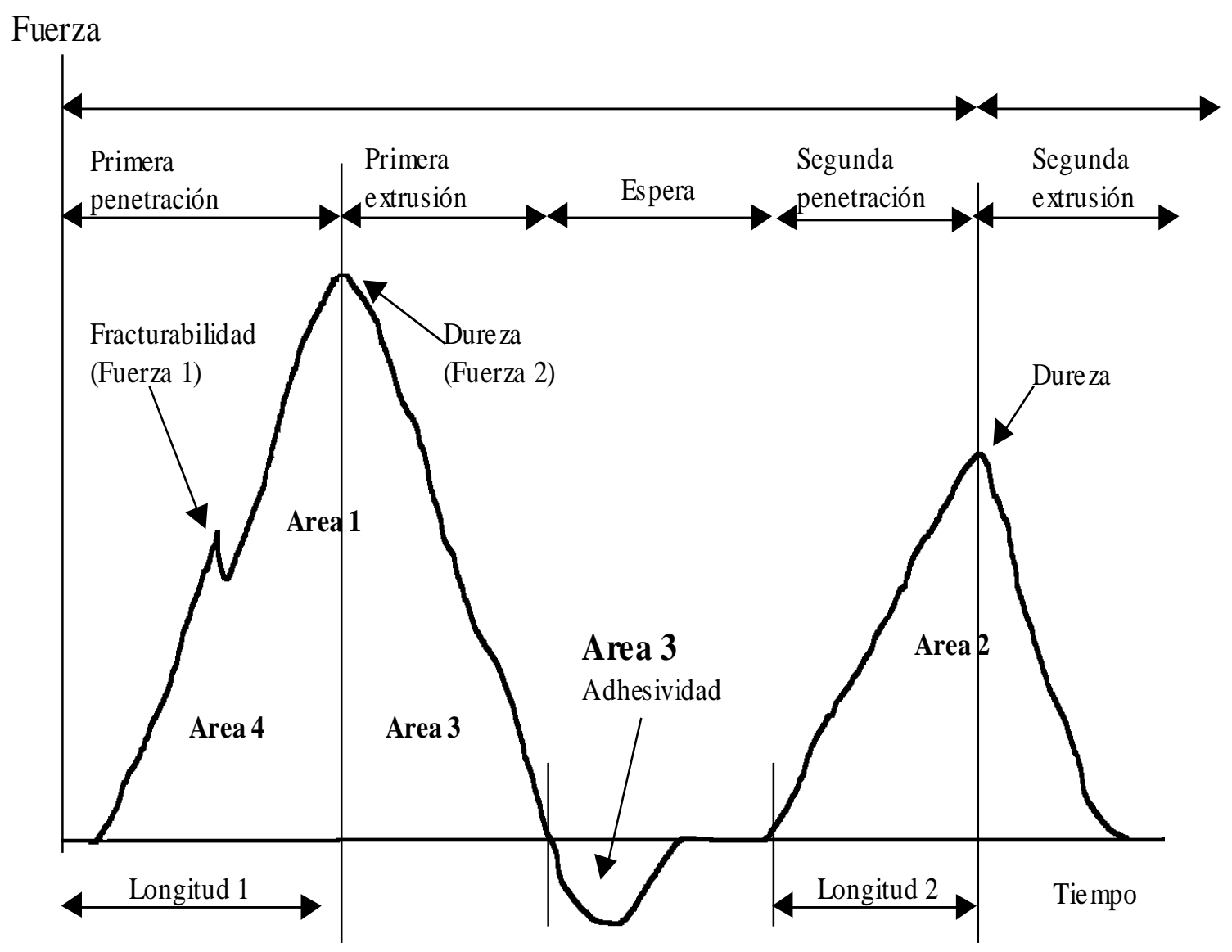

Figura 4. Curvas obtenidas del Análisis del Perfil de Textura 
CAPÍTULO III. METODOLOGÍA: DISEÑO EXPERIMENTAL Y TÉCNICAS DE ANÁLISIS

\section{CAPÍTULO III \\ METODOLOGÍA: DISEÑO EXPERIMENTAL Y TÉCNICAS DE ANÁLISIS}




\subsection{LECHE UTILIZADA}

Se utilizó leche entera de vaca pasteurizada y homogeneizada con $30 \mathrm{~g} \cdot \mathrm{L}^{-1}$ de grasa, $31 \mathrm{~g} \cdot \mathrm{L}^{-1}$ de proteína reportados en la etiqueta y una densidad de $1,032 \mathrm{~g} \cdot \mathrm{mL}^{-1}$ medida con un lactodonsímetro para leche (Santa Clara, Productos Lácteos SA de CV, Pachuca, Hidalgo, México).

\subsection{CULTIVOS INICIADORES}

Los cultivos iniciadores fueron preparados inoculando la cepa deseada en leche descremada con $10 \%\left(\mathrm{p} / \mathrm{v}\right.$ ) de sólidos totales (Svelty, Nestlé, Suiza), esterilizada a $121^{\circ} \mathrm{C}$ por $5 \mathrm{~min}$. Se incubaron a $37^{\circ} \mathrm{C}$ (Lactococcus lactis subsp. lactis y Lactococcus lactis subsp. cremoris) y $42^{\circ} \mathrm{C}$ (Streptococcus thermophilus) por 18 horas Se trabajaron dos condiciones para la elaboración de los quesos:

- Queso Control (QC): fue elaborado con 2\% (v/v) de cultivos mixtos de Lactococcus lactis subsp. lactis y Lactococcus lactis subsp. cremoris MA014 (Rhône-92, Poulenc, Francia) y $0.5 \%$ (v/v) de cultivo Streptococcus thermophilus TA050 no productor de exopolisacáridos (Rhône-92, Poulenc, Francia).

- Queso Filante (QF): fue elaborado con un $2 \%(\mathrm{v} / \mathrm{v})$ de cultivo iniciador mixto comercial de Lactococcus lactis subsp. lactis y Lactococcus lactis subsp. cremoris MA014 (Rhône-92, Poulenc, Francia) y 0.5\% (v/v) de cultivo productor de exopolisacáridos de la cepa Streptococcus thermophilus SY-102 (Rhodia-Texel Ltd., Londres RU). 


\subsection{MÉTODO DE ELABORACIÓN DE QUESO TIPO MANCHEGO}

Los quesos se prepararon por triplicado en lotes de $3.5 \mathrm{~L}$ con leche adicionada con $0.2 \mathrm{~mL} \cdot \mathrm{L}^{-1}$ de una disolución de cloruro de calcio al $0.3 \%$ (p/p).

\subsubsection{Maduración de la leche}

La leche se incubó a $37^{\circ} \mathrm{C}$ usando la mezcla de los cultivos correspondientes. Durante la maduración de la leche se midieron: la viscosidad, la acidez y el pH cada 30 minutos. Se midió la viscosidad aparente para determinar la presencia de exopolisacáridos (EPS), ya que está comprobado que la presencia de EPS aumenta la viscosidad de la leche debido a la interacción de los mismos con las proteínas y la grasa de la leche (Cerning y cols. 1986).

\subsubsection{Viscosidad aparente}

La viscosidad aparente de la leche madurada fue analizada por medio de un Viscosímetro Brookfield LV-DV III (Brookfield Engineering Laboratories Inc., Stoughton MA, E.U.). Se virtieron $400 \mathrm{~mL}$ de leche madurada en un vaso de precipitado de $500 \mathrm{~mL}$ y se tomaron lecturas cada $30 \mathrm{~min}$ (hasta llegar a $180 \mathrm{~min}$ ) con un vástago LV4 o ULA a una velocidad de 40 a 60 rpm respectivamente (Cerning y cols. 1986).

\subsubsection{Determinación de acidez total y $\mathrm{pH}$}

La acidez de la leche madurada fue determinada (por triplicado) por titulación con $0.1 \mathrm{~mol} \cdot \mathrm{L}^{-1}$ de $\mathrm{NaOH}$ (Sigma Chemicals, E.U.A.), usando fenolftaleína (Baker, J.T.) como indicador.

El pH se determinó con un potenciómetro (Conductronic pH 20, Puebla, México). Las determinaciones de $\mathrm{pH}$ y acidez total se realizaron por triplicado cada 30 minutos durante la maduración de la leche hasta completar 180 minutos. 


\subsubsection{Coagulación de la leche}

La maduración de la leche se detuvo a los 180 minutos al alcanzar un pH de 6.0, a este valor de $\mathrm{pH}$ la vicosidad de la leche fue máxima, y al bajar este valor la viscosidad comenzaba a decaer. La leche fue coagulada añadiendo $3.5 \mathrm{~mL}$ de cuajo microbiano diluido en $40 \mathrm{~mL}$ de agua destilada (fuerza del cuajo de 1:10000; Cuamex, Ciudad de México), y se incubó a 37º por 30 minutos aproximadamente hasta obtener un gel firme.

\subsubsection{Cortado, cocimiento y desuerado de la cuajada}

Después de la coagulación, se cortó la cuajada en cubos de aproximadamente $1 \mathrm{~cm}$ por lado y se mantuvo en reposo por $15 \mathrm{~min}$. Posteriormente, la temperatura se elevó lentamente $\left(1^{\circ} \mathrm{C} / \mathrm{min}\right)$ hasta alcanzar $45 \pm 2{ }^{\circ} \mathrm{C}$, agitando ligeramente la cuajada. Cuando la temperatura alcanzó los $45^{\circ} \mathrm{C}$, la cuajada se cortó en piezas pequeñas y se dejó drenar el $80 \%$ del suero, volteando las piezas ocasionalmente, hasta que el suero alcanzó una acidez titulable de 0.20$0.22 \%$ de ácido láctico.

\subsubsection{Moldeado y prensado}

La cuajada se puso en moldes de hierro forjado de $1 \mathrm{~kg}$ de capacidad recubiertos con gasa para el moldeado y se prensó en una prensa hidráulica por $24 \mathrm{~h}$ a presión constante de $1 \mathrm{~kg} \bullet \mathrm{cm}^{-2}$.

\subsubsection{Salado}

Después del prensado, los quesos se sumergieron en salmuera al $10 \%$ de $\mathrm{NaCl}$ por $24 \mathrm{~h}$ a $10^{\circ} \mathrm{C}$. 


\subsubsection{Maduración de los quesos}

Los quesos se sacaron de los moldes y se mantuvieron a temperatura ambiente por $2 \mathrm{~h}\left(20^{\circ} \mathrm{C}\right)$, posteriormente se metieron por 15 días en una cámara de maduración $\left(10^{\circ} \mathrm{C} \mathrm{a} 12^{\circ} \mathrm{C}\right.$, con una humedad relativa del $80 \%$ al $90 \%$ ). Cada tercer días se voltearon y se limpiaron con una solución de sorbato de potasio al $0.2 \%$.

\subsection{DETERMINACIÓN DEL RENDIMIENTO DE LOS QUESOS}

Se determinó el rendimiento en el QC y en el QF en las diferentes etapas de la producción: antes del salado, después del salado y después del madurado (Hart, 1991).

El rendimiento del queso se reportó como porcentaje. Dicho rendimiento se calculó obteniendo el cociente entre el peso final del queso y el peso de la leche utilizada, mediante la siguente fórmula:

$$
\% \text { del rendimiento del queso }=\frac{\text { Peso del queso }(\mathrm{g})}{- \text { Peso de la leche }(\mathrm{g})}
$$

Los cambios en el rendimiento de los quesos se calcularon por medio de la siguiente fórmula:

\% de cambio de rendimiento = $\begin{gathered}\text { Rendimiento Queso Filante }- \text { Rendimiento Queso Control } \\ \text { Rendimiento del Queso Control }\end{gathered}$

\subsection{ANÁLISIS FISICOQUÍMICO DE LOS QUESOS}

\subsubsection{Determinación de Sólidos Totales y Humedad}

La determinación de la humedad de un gramo de muestra se calculó por la diferencia de peso mediante la evaporación de agua en una estufa de desecación a $100^{\circ} \mathrm{C}$ (Thermolyne Type 19200, oven incubator. Sybron. Impulsora infisa S.A. de C.V.) hasta llegar a peso constante 
(Covarrubias y col., 1996; Kirk y cols., 1996; Jiménez-Guzmán y col., 2009). Se determinó por triplicado en el QC y el QF.

Los sólidos totales se calcularon por diferencia del peso total de la muestra y la humedad.

\subsubsection{Determinación de porciento de grasa, sólidos no grasos, grasa base seca y sólidos no grasos base seca}

Las determinaciones de sólidos no grasos (SNG), grasa base seca (GBS) y sólidos no grasos base seca (SNGBS) se determinaron después de obtener el porcentaje de grasa que fue determinado utilizando el método de Gerber (Jiménez-Guzmán y cols., 2009).

\subsubsection{Extracción y determinación de proteínas totales en queso}

Para la determinación de proteína total de los quesos, se realizó primero la extracción de proteínas según lo informado por Yong y Young (1996), y posteriormente se cuantificó por medio del método de Lowry.

Para la extracción de las proteínas se pesaron por triplicado $0.6 \mathrm{~g}$ de cada queso, se disolvieron en $25 \mathrm{~mL}$ de urea $8 \mathrm{~mol} \cdot \mathrm{L}^{-1}$ a pH 8.0 (Sigma Chemicals, Balcata, WA, Australia) y se homogenizaron por 2 minutos. Luego se metieron en baño María a $37^{\circ} \mathrm{C}$ por 2 horas para lograr la solubilización de las proteínas. Una vez trascurrido ese tiempo, se centrifugaron a 10,000 rpm por 30 minutos a $4^{\circ} \mathrm{C}$. Después se filtraron en papel Whatman Número 1 para remover la grasa y los sólidos solubles. El filtrado se dializó (membrana-cel MC30x100 CLR) por 24 horas en una solución amortiguadora de fosfatos $0.1 \mathrm{~mol} \cdot \mathrm{L}^{-1}$ a $\mathrm{pH}=7$ y posteriormente se determinaron las proteínas por el método de Lowry (Yong y Young, 1996 y Lowry y cols. 1951). 


\subsection{MICROSCOPIA ELECTRÓNICA DE BARRIDO}

Se realizaron las observaciones de los quesos por medio de Microscopía Electrónica de Barrido (SEM). A pesar de que las muestras sufrieron cierto grado de contracción, la técnica utilizada para deshidratar las muestras consistió en la sustitución gradual del agua por el etanol, seguido por la sustitución del etanol con $\mathrm{CO}_{2}$. Después de eso, el $\mathrm{CO}_{2}$ se sublimó rápidamente para dejar una muestra seca. Esta técnica permite la mejor preservación posible de la estructura original de la muestra. Por lo tanto, podemos suponer que a pesar de que la microestructura de los quesos puede haber cambiado durante el proceso, la estructura observada en las micrografías es muy parecida a la original.

\subsubsection{Preparación de la muestra}

a) Fijación

Se tomaron muestras, con un sacabocados, de los dos tipos de quesos (Queso Control y Queso Filante) después de los 15 días de maduración. Las muestras se tomaron de tres diferentes secciones del queso (centro, medio y corteza), y se realizaron cortes de las 3 diferentes secciones en cubos de aproximadamente $3 \times 3 \times 1 \mathrm{~mm}$, las cuales se colocaron para su fijación en un frasco que contenía una solución de glutaraldehído $\left(20 \mathrm{~mL} \cdot \mathrm{L}^{-1}\right)$ (Electrón Microscopy Science, Washington, DC, USA), durante 24 horas a $4^{\circ} \mathrm{C}$ con 5 $\mathrm{mg} \cdot \mathrm{L}^{-1}$ de rojo rutenio (Electrón Microscopy Science, Washington, DC, USA) para la tinción de los EPS.

\section{b) Post-fijación con osmio}

Posteriormente se colocaron las muestras en $20 \mathrm{~g} \cdot \mathrm{L}^{-1}$ de tetraóxido de osmio (Electrón Mycroscopy Science, Washington, DC, USA) para llevar a cabo un proceso de postfijación durante 2 horas a $4^{\circ} \mathrm{C}$.

\section{c) Deshidratación}

Después se llevó a cabo la deshidratación de las muestras colocándolas en alcohol etílico absoluto (J.T. Baker) a diferentes concentraciones (30\%, 50\%, 70\%, 80\%, $90 \%$ y 100\%), y se realizaron 3 lavados de 10 minutos en cada una de ellas. 


\section{d) Secado a punto crítico}

Se colocaron las muestras en cajas microporosas, las cuales se introdujeron en un equipo Samdri-780-B (Tousimis Research Corporation, Santa Clara, CA, 95054. USA), para su secado a punto crítico $\left(\mathrm{P}=1040 \mathrm{lb} / \mathrm{in}^{2}, 31^{\circ} \mathrm{C}\right)$ usando dióxido de carbono como medio de transición.

\section{e) Montaje}

Se colocaron las muestras en un portamuestras de aluminio con una cinta de carbono de doble vista. Se recubrieron con oro en un equipo Sputter Coater SCD 050 (Bal-Tec, Balzers, Lietchtenstein) con un espesor final de 150 Aº. (Jimenez-Guzmán, 2009)

\subsubsection{Observaciones en el Microscopio Electrónico de Barrido Diferencial}

Se observaron las muestras de los quesos en un Microscopio Electrónico de Barrido diferencial Zeiss DSM 940 Digital Scanning Microscope (Oberkochen, Alemania) con un haz de electrones $100 \%$ secundarios a $10 \mathrm{kv}$ y $20 \mathrm{kv}$.

\subsection{ANÁLISIS DEL PERFIL DE TEXTURA (APT)}

El Análisis del Perfil de Textura (APT) se llevó a cabo en un analizador de textura TA.XT2i (Stable Micro Systems, Texture Technologies Corp., White Plains, NY). Se obtuvieron muestras cilíndricas del centro del queso madurado 15 días mediante un sacabocados de 0.5 pulgadas, su altura se ajustó a $1.1 \mathrm{~cm}$ con un cuchillo. Las muestras se colocaron en cajas de Petri cerradas para evitar la pérdida de humedad y se mantuvieron a $20^{\circ} \mathrm{C}$ durante $1 \mathrm{~h}$, después se comprimieron un 60\% en dos ciclos, utilizando la sonda P50 a una velocidad de cruceta de $120 \mathrm{~mm} \bullet \mathrm{min}^{-1}$, y se analizaron cinco muestras de cada queso. Los atributos medidos fueron: dureza, elasticidad, cohesividad y masticabilidad. Dichos atributos se calcularon a partir de las curvas obtenidas por medio del software Texture Expert 1.20, (Stable Micro Systems Ltd., 1998) conectado directamente al equipo (Bourne, 1982). 


\subsection{ANÁLISIS SENSORIAL DE TEXTURA}

El Análisis Sensorial de Textura se realizó mediante la técnica de "Análisis Descriptivo Cuantitativo" con un panel seleccionado y entrenado de 10 personas.

Se usaron cuestionarios que emplearon escalas no estructuradas de $10 \mathrm{~cm}$ para expresar la intensidad percibida en cada propiedad de textura. Los panelistas trabajaron en forma individual con un número de 3 muestras por sesión, analizando cada muestra por duplicado.

Antes de realizar la evaluación, todas las muestras se cortaron en cubos de $1 \mathrm{~cm}^{3}$ y se estabilizaron a una temperatura de 14 a $16^{\circ} \mathrm{C}$ durante 1 hora. Se presentaron dentro de contenedores de unicel cerrados. Las muestras se identificaron con una clave de 3 dígitos elegidos al azar y el código utilizado fue diferente para cada ensayo.

El Perfil Sensorial de Textura comprendió los siguientes atributos: dureza, elasticidad, cohesividad y masticabilidad.

\subsubsection{Reclutamiento de los jueces}

Se reclutaron 50 personas entre profesores y alumnos de la UAM Iztapalapa que respondieron a la convocatoria realizada en la universidad.

\section{Encuesta de salud, hábitos alimenticios y entrevista personal}

A cada candidato se le hizo una entrevista personal para saber cuál era su interés y si tenían motivación suficiente para participar en el panel.

Se les aplicó una encuesta de salud y hábitos alimenticios para recabar sus datos personales, qué tipo de alimentos consumen, si tienen alguna alergia a algún tipo de alimento, si tienen rechazo por algún alimento, cuáles son sus hábitos alimenticios y si fuman o no, valorar su capacidad de comunicación y si son capaces de describir los atributos, y descartar asímismo que no tuvieran alguna enfermedad que impidiera que participaran en el entrenamiento (Cuestionario 1). 


\section{CAPÍTULO III. METODOLOGÍA: DISEÑO EXPERIMENTAL Y TÉCNICAS DE ANÁLISIS}

Se revisaron los cuestionarios aplicados y se hizo una primera selección con base en los resultados obtenidos, se evaluó si los candidatos eran aptos para valorar el queso, si consumen normalmente productos lácteos, si no tienen ninguna alergia o enfermedad y si no fuman o consumen alcohol.

Se descartaron a los candidatos que tuvieron alguna alergia a los productos lácteos o tuvieran rechazo hacia los mismos, los que tuvieron problemas de salud o tipos de anosmia. Los candidatos seleccionados pasaron a la siguiente etapa.

\subsubsection{Selección de jueces}

Se les hicieron algunas pruebas sensoriales a los candidatos seleccionados como: prueba de umbral para los cuatro sabores básicos: dulce, salado, amargo, ácido y pruebas de ordenación para los cuatro sabores básicos.

La finalidad de realizar este tipo de pruebas con los jueces fue detectar su umbral para los cuatro sabores básicos, así como saber cuál era su capacidad para detectar diferencias entre las concentraciones de las soluciones y poder valorar su capacidad discriminatoria. Además fue una forma para que se fueran familiarizando con las pruebas sensoriales.

\section{a) Prueba de detección de sabores básicos y umbrales}

Se prepararon soluciones acuosas de los productos químicos representativos de los cuatro sabores básicos y las sensaciones gustativas en las siguientes proporciones como se muestra en la Tabla 12:

Tabla 12. Soluciones de los 4 sabores básicos

\begin{tabular}{|c|l|c|}
\hline Sabor básico & Sustancia patrón & Concentración $\mathbf{g} \cdot \mathbf{L}^{\mathbf{1}}$ \\
\hline Ácido & Acido cítrico & 0.6 \\
\hline Amargo & Cafeína cristalizada & 0.27 \\
\hline Salado & Cloruro de sodio & 2 \\
\hline Dulce & Sacarosa & 5.76 \\
\hline
\end{tabular}




\section{CAPÍTULO III. METODOLOGÍA: DISEÑO EXPERIMENTAL Y TÉCNICAS DE ANÁLISIS}

\section{Preparación de la prueba}

Se le presentaron nueve vasos con las diferentes soluciones a cada juez; se decidió previamente el orden de presentación y la repetición de muestras. Cada muestra se codificó con una clave formada por un conjunto de 3 números aleatorios. Se anotaron las claves y el orden de presentación para llevar un registro. Se procedió a llenar los vasos desechables con $20 \mathrm{~mL}$ de solución en el orden establecido. Se ordenaron en charolas para ser servidas a los jueces. Se colocó un vaso de agua purificada en cada charola para el enjuague y un vaso grande para que el juez pudiera expectorar. Adicionalmente, se le presentó a cada juez un cuestionario para dicha prueba. Cada juez procedió a realizar la prueba degustando cada muestra en el orden establecido y contestando en el cuestionario correspondiente (Cuestionario 2).

Se vaciaron los resultados en una tabla poniendo un "0" si el juez no respondió correctamente y un "1" si respondió correctamente. Se procedió a realizar una gráfica con los resultados obtenidos de concentración de la sustancia contra frecuencia de reconocimiento (en porcentaje), se obtuvo la regresión lineal y se calculó el umbral absoluto que corresponde al $50 \%$ en que los jueces reconocieron el gusto básico del que se trataba.

\section{b) Pruebas de ordenación}

Se preparan cuatro muestras con diferentes intensidades de un sabor básico (dulce, salado, amargo y ácido) para cada prueba. Las muestras de cada atributo se presentaron al azar a los jueces. Se les pidió que ordenaran las muestras según el incremento de intensidad de dicho atributo.

Las intensidades utilizadas para cada atributo fueron las que están indicadas en la Tabla 13: 
Tabla 13. Soluciones de diferentes concentraciones de sabores básicos

\begin{tabular}{|l|l|l|}
\hline Sabor & Sustancia & Concentración (\%) \\
\hline Dulce & Sacarosa & $1.0,2.0,4.0$ \\
\hline Ácido & Ácido cítrico & $0.035,0.07,0.014$ \\
\hline Salado & $\mathrm{NaCl}$ & $0.1,0.2,0.4$ \\
\hline Amargo & Cafeína & $0.035,0.07,0.014$ \\
\hline
\end{tabular}

Las muestras se presentaron de manera que sólo el parámetro en estudio fuera variable (Cuestionario 3).

Se seleccionaron los jueces que atinaron al $60 \%$ de las respuestas correctas. Fueron seleccionados 20 jueces para seguir a la etapa de entrenamiento.

\subsubsection{Entrenamiento de jueces}

El entrenamiento consistió en conseguir que los jueces se familiarizaran con las muestras y aprendieran la metodología de las pruebas. También se verificó si son capaces de discriminar entre una muestra y otra.

Se observaron las diferencias entre los jueces durante todo el proceso de entrenamiento para indagar qué juez se desviaba de las mediciones y determinar si seguía en las evaluaciones o era descartado.

Para el entrenamiento se utilizaron quesos comerciales para familiarizar al juez con los diferentes atributos que iba a evaluar y para entrenarlos en el manejo de escalas.

A continuación, se presentan en la Tabla 14 las muestras comerciales utilizadas: 
Tabla 14. Quesos comerciales utilizados en el entrenamiento de los jueces

\begin{tabular}{|l|l|}
\hline Producto & Marca \\
\hline $\begin{array}{l}\text { Las marcas de los quesos comerciales fueron las } \\
\text { siguientes: }\end{array}$ & \\
Queso tipo Manchego & Nochebuena (Sigma Alimentos) \\
Queso panela & Nochebuena (Sigma Alimentos) \\
Queso Oaxaca & La Franja \\
Queso crema & Cubiquesito Kraft \\
Queso tipo gruyere & Europeam gourmet \\
Queso de cabra & Ste Maure Laclette \\
Queso tipo parmesano & Grand Duramont (Riggattello) \\
Queso cotija & Nochebuena (Sigma Alimentos) \\
Queso tipo gouda & Nochebuena (Sigma Alimentos) \\
\hline
\end{tabular}

\subsubsection{Etapas del entrenamiento}

\section{a) Definición y descripción de atributos}

En esta primera etapa del entrenamiento se les solicitó a los jueces que generaran todos los descriptores de textura que les vinieran a la mente al probar una muestra de queso tipo Manchego comercial (Nochebuena), y que los escribieran en una hoja con sus respectivas definiciones. Después se les proporcionó una lista de atributos de textura del queso para que la compararan con lo que ellos habían escrito. Esta parte del entrenamiento se llevó a cabo en una sesión de una hora.

\section{b) Consenso entre jueces sobre las definiciones de los descriptores}

Después se procedió a hacer una sesión grupal, donde se refinó el lenguaje generado por los jueces, eliminando sinónimos, antónimos y terminología que no aplicaba para la muestra de queso. El consenso se llevó a cabo en una sesión de dos horas.

Estas sesiones grupales para llegar a un consenso son de suma importancia para establecer un acuerdo sobre las definiciones de cada atributo y asegurarse de que cada juez entiende lo mismo para cada atributo. 


\section{CAPÍTULO III. METODOLOGÍA: DISEÑO EXPERIMENTAL Y TÉCNICAS DE ANÁLISIS}

Una vez que se discutieron las definiciones para cada atributo y que se llegó a un acuerdo sobre las mismas, se aseguró de que todos los jueces entendieran lo mismo para cada atributo. Estas definiciones se escribieron en una tabla para usarla posteriormente a lo largo de todo el entrenamiento como apoyo a la hora de realizar las pruebas.

\section{c) Pruebas de diferenciación}

\section{Prueba Dúo - Trío}

Se aplicaron pruebas Dúo-Trío para entender mejor algunos atributos, como la cohesividad, que es un poco difícil de medir (Cuestionario 4).

Se utilizaron muestras de quesos comerciales. Se realizaron seis series de muestras de quesos comerciales por duplicado. Esta prueba se llevó a cabo en una sesión de una hora.

La prueba consistió en presentar al juez tres muestras, dos de ellas codificadas con una clave de tres números aleatorios y una marcada como Referencia $(\mathrm{R})$. Se le pidió al juez que probara las muestras de izquierda a derecha y de arriba hacia abajo y que subrayara la muestra que fuera igual a " $R$ ".

Se vaciaron los datos en una tabla donde se anotó un "0" cuando los jueces no atinaron a la respuesta correcta y un "1" cuando si lo hicieron. Luego, se sumaron las frecuencias y se procedió a calcular la $\chi$-cuadrada. Se obtuvo la conclusión estadística de la siguiente manera: si el valor calculado de $\chi$-cuadrada resultó mayor que el valor en las tablas, se rechazó $\mathrm{H}_{0} \mathrm{y}$, por lo tanto, se concluyó que el juez no encontró diferencias significativas entre las muestras; si el valor calculado fue menor que el valor en las tablas (Tablas de $\chi$-cuadrada, con 0.05 de significancia), se aceptó $\mathrm{H}_{0} \mathrm{y}$, por lo tanto, se puede concluir que el juez sí encontró diferencias significativas entre las muestras.

\section{Prueba de Comparación por pares}

Se aplicaron pruebas de "Comparación por pares" para los atributos de: cohesividad, masticabilidad, dureza, elasticidad. (Cuestionario 5). 


\section{CAPÍTULO III. METODOLOGÍA: DISEÑO EXPERIMENTAL Y TÉCNICAS DE ANÁLISIS}

Se utilizaron muestras de quesos comerciales. Se realizaron cinco series de muestras de quesos comerciales por duplicado. Estas pruebas se llevaron a cabo en cinco sesiones de 30 minutos cada una.

La finalidad de dichas pruebas fue establecer si los jueces tenían capacidad discriminativa, además de que se fueran familiarizando con las pruebas y con los atributos

Los resultados se vaciaron en tablas donde se escribió "0" cuando no acertaron a la respuesta correcta y un "1" cuando atinaron a la respuesta correcta. Los datos se analizaron por $\chi$-cuadrada con un 0.05 de significancia, y concluir así si las muestras eran percibidas por los jueces como diferentes o no.

\section{Manejo de escalas (Escalas de referencia)}

Las escalas normalizadas se desarrollaron sobre la base de la clasificación de cuatro atributos de textura del queso elegidos para nuestros análisis con el objeto de proporcionar un método cuantitativo para evaluar sus propiedades mecánicas.

Se desarrollaron escalas de referencia para los siguientes atributos: dureza, elasticidad, cohesividad y masticabilidad. Para cada escala se escogieron cinco quesos comerciales que sirvieron como cinco puntos de referencia para cada una de las escalas.

Las escalas de referencia para cada atributo se muestran en la Tabla 15, donde $1=$ muy poco intenso, $2=$ poco intenso, $3=$ intensidad media, $4=$ intenso y $5=$ muy intenso:

Tabla 15. Escalas de referencia utilizadas para el entrenamiento de los jueces

\begin{tabular}{|l|l|l|l|}
\hline DUREZA & COHESIVIDAD & ELASTICIDAD & MASTICABIIDAD \\
\hline 1.- Queso crema & 1.- Queso cotija & 1.- Queso crema & 1.- Queso crema \\
2.- Queso panela & 2.- Queso panela & 2.- Queso panela & 2.- Queso tipo Manchego \\
3.- Queso tipo Manchego & 3.- Queso tipo gruyere & 3.- Queso tipo Manchego & 3.- Queso oaxaca \\
4.- Queso tipo gruyere & 4.- Queso tipo Manchego & 4.- Queso tipo gouda & 4.- Queso tipo parmesano \\
5.- Queso tipo parmesano & 5.- Queso tipo gouda & 5.- Queso oaxaca & 5.- Queso tipo gruyere \\
\hline
\end{tabular}

Para familiarizarse con dichas escalas se realizaron dos sesiones de una hora de duración donde los jueces probaron los quesos correspondientes a cada una de las escalas de cada atributo. 


\section{CAPÍTULO III. METODOLOGÍA: DISEÑO EXPERIMENTAL Y TÉCNICAS DE ANÁLISIS}

También se trabajó con pruebas de ordenación para asegurarse de que los jueces entendieron bien la escala y sus atributos correspondientes. Más adelante se hicieron pruebas descriptivas con anclajes para ayudar a los jueces a que se orientaran dentro de la escala. Estas pruebas se describen a continuación.

\section{Pruebas de ordenación}

Se hicieron pruebas de ordenación en series de cuatro muestras por duplicado para cada uno de los cinco atributos. Se llevaron a cabo en cinco sesiones de 30 minutos cada una.

La prueba consistió en presentar a los jueces una serie de cuatro muestras en orden aleatorio. Se les pidió que ordenaran dichas muestras en forma creciente según un cierto atributo (dureza, elasticidad, cohesividad o mastibabilidad), asignando un 1 a la muestra menos intensa en dicho atributo y un 4 a la más intensa según se indica en el Cuestionario 6.

Una vez realizadas las pruebas se vaciaron los resultados en una tabla y se analizaron estadísticamente por medio de la Prueba de Ordenación por Rangos de Newell Mc Farlene, la cual determinó si los jueces ordenaron las muestras de forma adecuada.

Es muy importante mencionar que en cada prueba estadística se determinó si había diferencia entre los jueces para irlas ajustando y poder establecer si eran aptos para evaluar las pruebas finales o no.

\section{Pruebas descriptivas con anclajes}

Las Pruebas Descriptivas Cuantitativas sirven para identificar y cuantificar los atributos sensoriales, en este caso, del queso. La información generada en dicha prueba sirve para construir un modelo multidimensional cuantitativo que muestra el perfil de los atributos más importantes del queso.

La prueba consiste en proporcionar un cuestionario al juez con una escala no estructurada de $10 \mathrm{~cm}$ de longitud, donde dicho el juez deberá anotar el nivel de intensidad que percibe de cada atributo del queso, como se muestra en el Cuestionario 7.

Se aplicaron pruebas descriptivas de ensayo para cada atributo de textura del queso por duplicado y con anclajes a los extremos. Se requirieron dos sesiones de una hora cada una. Se utilizaron los quesos de prueba elaborados en el laboratorio: el QC y el QF. 


\section{CAPÍTULO III. METODOLOGÍA: DISEÑO EXPERIMENTAL Y TÉCNICAS DE ANÁLISIS}

Una vez que los jueces respondieron, se midió cada respuesta en centímetros y dichos datos se vaciaron en una tabla. Posteriormente se calculó una t-student para cada atributo para averiguar si hubo diferencia significativa entre el QC y el QF, y una ANOVA para ver si había diferencia significativa entre los jueces.

De esta forma se pudo determinar si todos los jueces estaban midiendo de forma similar o había algunos jueces que se desviaban de las respuestas.

Una vez comprobando que los jueces habían entendido las escalas y que respondían de manera similar, se dio por concluido el entrenamiento y se procedió a realizar las pruebas definitivas.

\subsubsection{Pruebas Descriptivas Cuantitativas (Pruebas definitivas)}

Se hicieron Pruebas Descriptivas Cuantitativas para el QC y el QF, donde se midieron los siguientes atributos: Dureza, Elasticidad, Cohesividad y Masticabilidad. Se realizaron las pruebas por duplicado y con los 10 Jueces seleccionados para la prueba final. Las pruebas se realizaron en dos sesiones de una hora de duración. Se les solicitó a los jueces que probaran una muestra y respondieran en la escala no estructurada de $10 \mathrm{~cm}$ la intensidad percibida de cada uno de los atributos (Cuestionario 8).

Se midieron los centímetros de cada percepción en la escala, se vaciaron los resultados en una tabla y se calculó la t-student para saber si había diferencia significativa para cada uno de los atributos entre el QC y el QF. También se calculó la ANOVA para comprobar si había diferencia significativa entre los jueces. Después se procedió a calcular la media para cada queso y cada atributo, y se elaboró una gráfica radial para poder observar el perfil de textura de cada uno de los quesos y notar sus diferencias entre cada uno de los atributos. 


\subsection{ANÁLISIS ESTADÍSTICOS}

Los resultados fueron analizados a través de un análisis de varianza (ANOVA) utilizando un software de análisis estadístico (Statistica 5.0, Stat Soft, Tulsa OK EE.UU.), con una p <0.05.

Se emplearon las siguientes pruebas estadísticas para la evaluación sensorial: t-student para sacar las diferencias de cada uno de los atributos entre los dos tipos de quesos; $\chi$ cuadrada para las pruebas de diferenciación: la Prueba Triangulas, Comparación por pares y Dúo-Trío; ordenación por rangos a través de las tablas de Newell MacFarlene; y ANOVA para obtener las diferencias entre los jueces. Además se realizó un análisis de componentes principales (ACP) utilizando el software Minitab 14.0. 


\section{CAPÍTULO IV. RESULTADOS Y DISCUSIÓN}




\section{CAPÍTULO IV. RESULTADOS Y DISCUSIÓN}

\section{1 pH, ACIDEZ Y VISCOSIDAD APARENTE EN LA MADURACIÓN DE LA LECHE}

Los resultados de $\mathrm{pH}$, acidez y viscosidad aparente obtenidos durante la maduración de la leche destinada a la elaboración del queso control sin cepa filante (LC) y la leche utilizada en la elaboración del queso elaborado con cepa filante (LF) se muestran en la Figura 5.

Los resultados indican que no se observaron diferencias significativas de $\mathrm{pH}$ y acidez de las leches LC y LF a lo largo de toda su maduración, lo que corrobora que ambas cepas crecieron de forma similar. La continua disminución de $\mathrm{pH}$ y el aumento de la acidez en la maduración de las leches, revela que los cultivos iniciadores se desarrollaron de forma adecuada con la consiguiente producción de ácido láctico como parte de la vía metabólica fermentativa de las bacterias ácido lácticas (BAL) (De Vuyust y Degeest, 1999). En la elaboración de queso, la acidez es importante porque favorece la formación de la cuajada y evita además el desarrollo de otras bacterias indeseables en el producto (Richard y cols., 1990).

La maduración se detuvo cuando se alcanzó un pH de 6, debido a que a ese valor se favorece la acción del cuajo y se produce una mayor viscosidad; cuando el pH es más bajo la viscosidad producida en la LF comienza a disminuir

Como se ha reportados por algunos investigadores, cuando se lleva a cabo la fermentación a un $\mathrm{pH}$ alrededor de 5.8 o 6.0, se incrementa la concentración de EPS en relación a valores de pH superiores (Kimmel y Roberts, 1998; Petry y cols., 2000; Dassy y cols., 1991; Hardy y cols., 1981).

Los EPS que producen algunas BAL en leches maduradas se han medido por medio de observaciones visuales o por mediciones de la viscosidad (Rawson y Marshall, 1997; Hess y cols., 1997), aunque también se ha podido cuantificar en leches fermentadas y en yogurt (Cerning, 1995; García-Garibay y Marshall, 1991; Domínguez-Soberanes y cols., 2001), pero estos métodos son muy largos y complicados en el queso.

Como se puede observar en la Figura 5, la viscosidad aparente de las leches LC y LF

aumentó y fue constante para ambas durante la primera hora de la maduración. Después de los 


\section{CAPÍTULO IV. RESULTADOS Y DISCUSIÓN}

90 min se elevó ligeramente, pero sin mostrar aun diferencias significativas. Cuando el pH alcanzó un valor inferior a 6.2, después de los 120min de la maduración, la viscosidad aparente de la leche LF se incrementó significativamente con respecto a aquella de la leche LC, a pesar del hecho de que el pH disminuyó y la acidez aumentó por igual en ambas leches.

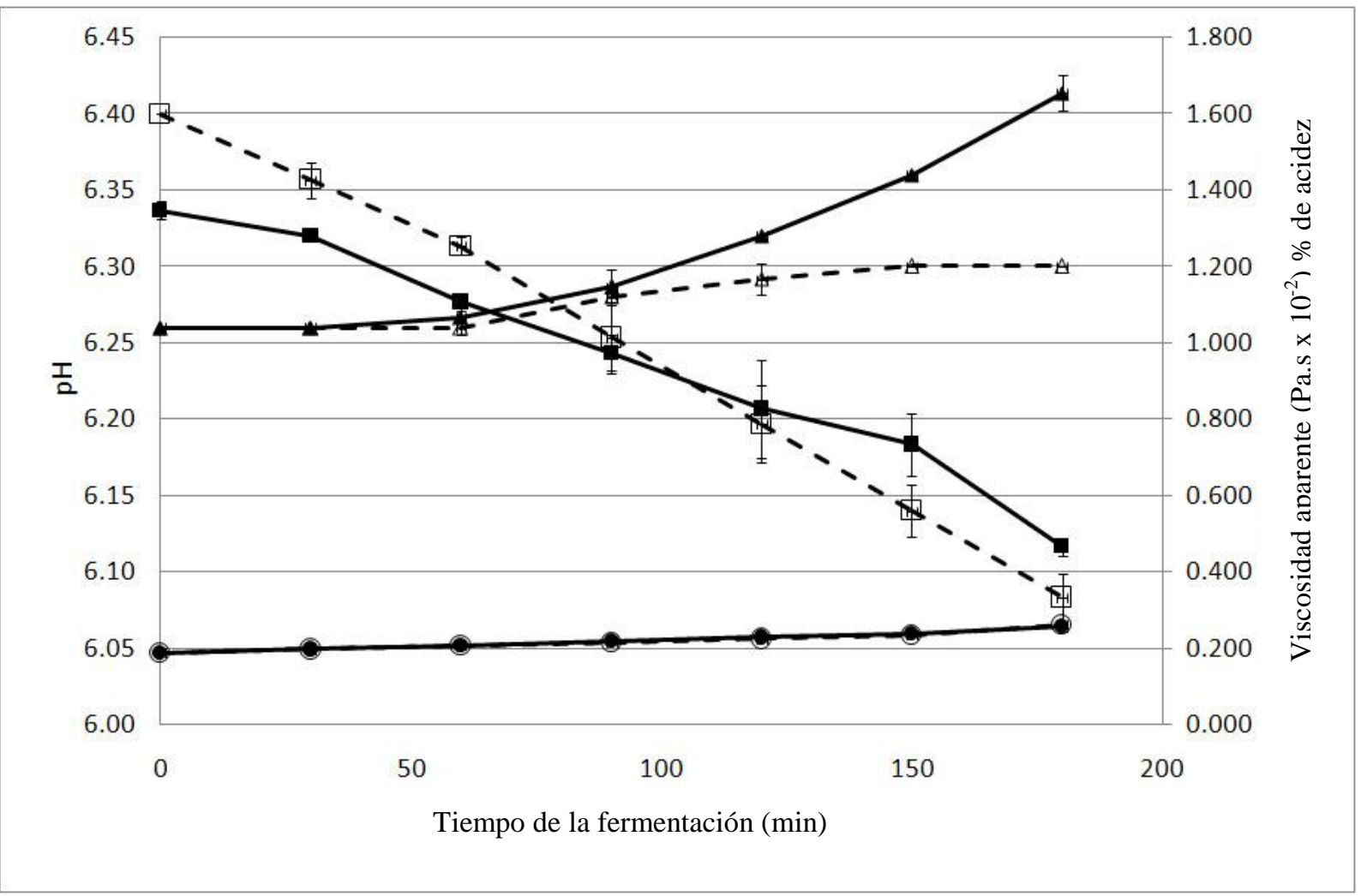

Figura 5. Viscosidad aparente (१), pH y acidez a lo largo de la maduración de las leches LC y LF.

$\square \mathrm{pH} L \mathrm{~L}, \quad \square \mathrm{pH} L F, \quad \triangle \mathrm{LC}, \quad \quad \quad \mathrm{LF}, \quad$ Qcidez LC, $\quad$ Acidez LF.

La medición de la viscosidad aparente de la leche durante su maduración fue utilizada como un indicador indirecto de la producción de EPS, ya que se ha comprobado que los incrementos en la viscosidad aparente de leche acidificada se deben a la interacción entre las moléculas de EPS y las proteínas. En el caso de las caseínas, se ha observado que un aumento en la concentración de EPS produce una mayor agregación de proteínas y, por lo tanto, una mayor viscosidad (Wacher-Rodarte, y cols., 1993; Broadbent, y cols., 2001; Champagne, y 


\section{CAPÍTULO IV. RESULTADOS Y DISCUSIÓN}

cols., 2006; Guzel-Seydim, y cols., 2005). Los complejos proteína-polisacárido se mantienen unidos por interacciones electrostáticas o enlaces covalentes, por lo que dichos complejos pueden aumentar la viscosidad en el medio (Dickinson, 1995). Con base en lo expuesto, se puede inferir, que el aumento en la viscosidad aparente de la leche LF demuestra la produción de EPS (Cerning, 1995; De Vuyst y Degeest, 1999).

Algunos estudios han demostrado que el pH óptimo para la producción de EPS por algunas bacterias ácido lácticas es de 6 (Cerning y cols., 1990). También existen otros factores que favorecen la producción de los mismos, como son el estrés que puede sufrir la bacteria, por ejemplo, una temperatura de crecimiento no óptima. Esta propiedad se aprovechó para lograr una mayor producción de EPS haciendo crecer la bacteria a una temperatura menor $\left(37^{\circ} \mathrm{C}\right)$ que su temperatura óptima de crecimiento que es de $42-45^{\circ} \mathrm{C}$, por ser un microorganismo termófilo (De Vuyst y Degeest, 1999).

\subsection{COMPOSICIÓN FISICOQUÍMICA Y RENDIMIENTO DE LOS QUESOS}

El análisis de la composición fisicoquímica de los quesos se muestra en la Tabla 16, donde se observa que la humedad y la grasa resultaron significativamente más altas en el queso elaborado con cepa filante $(\mathrm{QF})$ con respecto al queso elaborado con la cepa control (QC), mientras que se obtuvo una disminución significativa en el contenido de proteína total para el QF.

El hecho de que el QF haya resultado con un mayor contenido de humedad y grasa y una cantidad menor de proteína, se debe a la compleja estructura formada por la red de las proteínas y su interacción con los EPS, lo cual está relacionado con un cambio en la textura del queso. Esto también ha sido reportado por algunos estudios realizados en yogurt realizados por Domínguez-Soberanes y cols. (2001) y Hess y cols. (1997), quienes determinaron que el contenido de proteínas es más alto en cuanto mayor sea la interacción EPS con las proteínas de la leche, lo cual provoca un cambio en las propiedades de textura del producto; sin embargo, a pesar de que la cantidad de proteínas para el QF fue ligeramente menor, las interacciones proteína-EPS contribuyeron a una modificación en la textura de los quesos debido a la matriz 


\section{CAPÍTULO IV. RESULTADOS Y DISCUSIÓN}

de proteínas formada, donde los EPS quedan ligados, lo cual se comprobó en el aumento de la viscosidad aparente durante la maduración de la leche (Hess y cols. 1997; DomínguezSoberanes y cols. 2001). Esta matriz de proteínas-EPS puede retener más grasa y agua como se demuestra en el análisis físicoquímico del queso (Tabla 16).

Tabla 16. Composición fisicoquímica de los quesos $\left(\mathrm{g} \cdot 100 \mathrm{~g}^{-1}\right)$

\begin{tabular}{|l|c|c|c|c|c|c|}
\hline & $\begin{array}{c}\text { Sólidos } \\
\text { Totales }(\%)\end{array}$ & $\begin{array}{c}\text { Humedad } \\
(\%)\end{array}$ & $\begin{array}{c}\text { Grasa } \\
\text { Base } \\
\text { Húmeda } \\
(\%)\end{array}$ & $\begin{array}{c}\text { Proteínas } \\
\text { totales Base } \\
\text { Húmeda } \\
(\%)\end{array}$ & $\begin{array}{c}\text { Grasa Base } \\
\text { Seca }(\%)\end{array}$ & $\begin{array}{c}\text { Proteínas } \\
\text { totales Base } \\
\text { Seca (\%) }\end{array}$ \\
\hline Queso Control & $59.7 \pm 0.5^{\mathrm{a}}$ & $40.3 \pm 0.5^{\mathrm{a}}$ & $30 \pm 0.0^{\mathrm{a}}$ & $21.0 \pm 1.2^{\mathrm{a}}$ & $50.3 \pm 1.0^{\mathrm{a}}$ & $35.3 \pm 0.6^{\mathrm{a}}$ \\
\hline Queso Filante & $55.3 \pm 0.2^{\mathrm{b}}$ & $44.7 \pm 0.2^{\mathrm{b}}$ & $34 \pm 0.0^{\mathrm{b}}$ & $19.0 \pm 1.0^{\mathrm{b}}$ & $61.5 \pm 1.0^{\mathrm{b}}$ & $34.3 \pm 0.1^{\mathrm{b}}$ \\
\hline
\end{tabular}

a,b Las letras de los superíndices muestran diferencias significativas $(\alpha<0.05)$.

Por lo tanto, la red formada por las proteínas del queso y los EPS es un sistema complejo donde parecen estar involucradas uniones de tipo electrostáticas, enlaces covalentes y uniones de tipo hidrófobas, al igual que ciertos grupos $\mathrm{OH}$ de los polisacáridos, que son grupos polares y que contienen $\mathrm{H}$ y pueden formar puentes de hidrógeno con el agua, lo que provoca que ésta se ligue más fuertemente y, por ende, se retenga más en el QF. Estas interacciones hacen que también se retenga más grasa en dicho queso ya que queda atrapada en la red de proteínas (McClements, y cols., 2006; Dickinson, y cols., 1998).

El hecho de que haya habido un aumento significativo en la cantidad de humedad y grasa en el QF (Tabla 16), explica por qué resultó ser un queso con mayor rendimiento, como lo observamos en la Tabla 17. Algunos investigadores reportaron conclusiones similares en queso Cheddar bajo en grasa elaborado con cepa; ellos obtuvieron un mayor contenido de humedad, un porcentaje superior de grasa y un incremento en el rendimiento del queso filante (Rynne y cols., 2007).

En la Tabla 17 se muestra el rendimiento de los quesos antes del salado, después del salado y después del madurado. Los resultados obtenidos muestran que el rendimiento del QF fue significativamente mayor que en el QC en las tres etapas de elaboración: antes del salado, después del salado y después del madurado. Estos resultados pueden explicarse por el efecto 


\section{CAPÍTULO IV. RESULTADOS Y DISCUSIÓN}

de los EPS para retener humedad y grasa y, por lo tanto, para incrementar el rendimiento del queso (Kalab y col., 1993; Wacher-Rodarte, y cols., 1993; Teggatz y Morris, 1990; GarcíaGaribay y Marshall, 1991).

Antes del salado se obtuvo un aumento significativo en el rendimiento de $10.8 \%$ para QF con respecto al QC, lo cual refleja que hubo retención de agua y grasa debido a las interacciones de los EPS aún después del proceso de prensado, como se observa en la Tabla 16.

El proceso de salado se hizo por inmersión en salmuera, por lo que ambos quesos aumentaron de peso por la retención de agua (Tabla 17). En esta etapa el QF siguió mostrando un aumento significativo en el rendimiento con respecto al QC (7.4\%), aunque entre antes del salado y después del salado no haya habido aumento significativo de peso en el QF. Esto puede deberse probablemente al hecho de que los EPS ya habían retenido tanta agua como podían, y por lo tanto, ya no podían absorber más.

Tabla 17. Rendimiento de los quesos

\begin{tabular}{|l|c|c|c|}
\hline & Antes del salado & Después del salado & Después de madurado \\
\hline Queso Control & $11.16 \pm 0.19^{\mathrm{a}}$ & $11.67 \pm 0.07^{\mathrm{a}}$ & $9.43 \pm 0.04^{\mathrm{a}}$ \\
\hline Queso Filante & $12.37 \pm 0.28^{\mathrm{b}}$ & $12.53 \pm 0.28^{\mathrm{b}}$ & $10.45 \pm 0.06^{\mathrm{b}}$ \\
\hline $\begin{array}{l}\text { \% de cambio de } \\
\text { rendimiento }\end{array}$ & 10.8 & 7.4 & 10.9 \\
\hline
\end{tabular}

a,b Los datos con diferentes subíndices muestran valores de diferencia significativa $(\alpha<0.05)$

El rendimiento del QF después del madurado, fue significativamente mayor obteniendo un incremento del 10.9\% respecto al QC. Esto es de gran importancia, ya que el aumento de rendimiento puede ser consecuencia de la capacidad de los EPS para retener agua y grasa, lo cual impide que el agua se evapore durante su maduración (Tabla 16), y esto se refleja en el producto final como un mayor peso; ésto puede beneficiar la estructura del queso al modificar su textura. Merrill y cols. (1994) demostraron que el uso de cepas productoras de EPS 


\section{CAPÍTULO IV. RESULTADOS Y DISCUSIÓN}

aumenta los niveles de la humedad en quesos Mozzarella reducidos en grasa, mejoran el cuerpo, la textura, y las características funcionales del queso (Merrill y cols., 1994).

Costa y cols. (2012), por su parte, estudiaron el efecto de los EPS producidos por Lactococcus lactis subsp. cremoris en la elaboración de queso Cheddar reducido en grasa y encontraron que los EPS producidos por este cultivo iniciador no interfirieron con la coagulación, pero si tuvo un efecto significativo en la reducción de la sinéresis después del corte de la cuajada (Costa y cols., 2012). Además de la funcionalidad mejorada, la capacidad de aumentar el nivel de la humedad del queso (incluso tan pequeño como el 1\%) da a los productores una ventaja económica importante en una industria altamente competitiva (Low y cols., 1998).

La Figura 6 muestra la pérdida de peso a lo largo de los 15 días de la maduración de los quesos. Se puede observar que hubo una mayor pérdida de peso en el QC en relación al QF a lo largo de toda la maduración.

Durante los 15 días de maduración de los quesos, se perdió peso debido a la evaporación de agua. Como se muestra en la Figura 6, la pérdida de peso durante la maduración en el QF fue significativamente menor (16.55\%) que para el QC (19.16\%). Esta menor pérdida de peso para el QF pudo deberse a la capacidad que tienen los EPS para retener agua, como lo comprueban algunos estudios realizados en el queso panela. Jiménez-Guzmán y cols. (2009), encontraron que cuando se utilizó una cepa productora de EPS, se incrementó el rendimiento en el queso mexicano tipo panela, de un $13.7 \%$ (queso control) a un $16.8 \%$ (queso filante). Sin embargo, dado que el queso panela es un queso fresco con un alto contenido de humedad, el incremento fue mayor que el mostrado en el queso tipo Manchego que es un queso prensado y madurado, en el cual se obtuvo un incremento en el rendimiento del $10.09 \%$. 


\section{CAPÍTULO IV. RESULTADOS Y DISCUSIÓN}

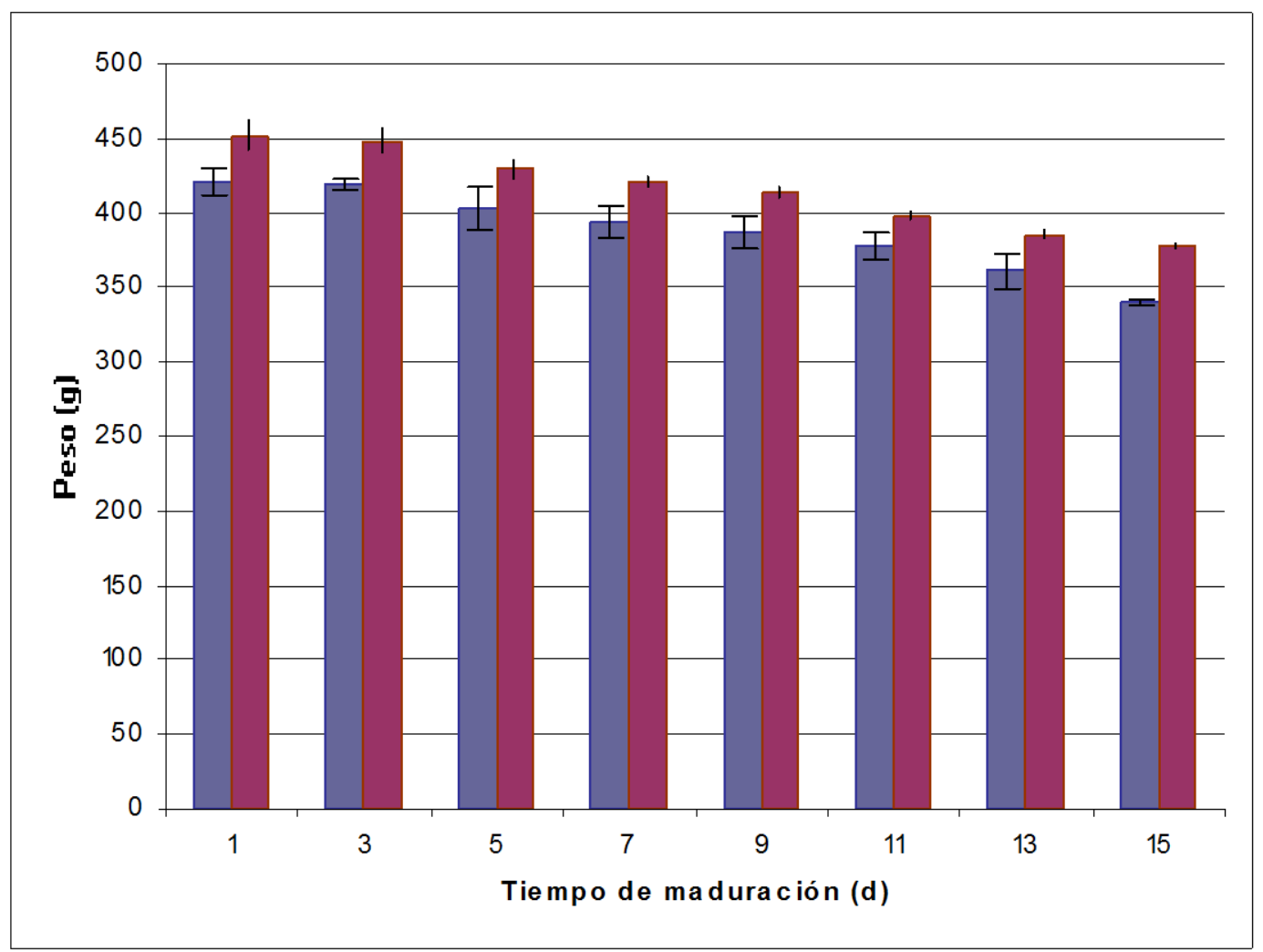

Figura 6. Variación de peso de los quesos durante la maduración.

Queso Control,

Queso Filante

\subsection{MICROESTRUCTURA}

En las Figuras 7a, 7b, 7c y 8a, 8b, 8c se muestran las microestructuras obtenidas mediante Microscopía Electrónica de Barrido (SEM) de tres secciones del QC y QF. Las Figuras 7a y 8a corresponden a la corteza del QC y del QF respectivamente; la parte media se ilustra en las Figuras 7b y 8b del QC y del QF respectivamente y el centro se observa en las Figuras 7c y 8c del QC y del QF respectivamente.

En particular, las Figuras 7a, 7b y 7c muestran las micrografías obtenidas por SEM del QC, en las cuales se demuestra que no hubo producción de EPS; se observa sólo una matriz de proteínas formada y glóbulos de grasa, lo cual concuerda con otros estudios reportados anteriormente (Dominguez-Soberanes, 2001; Hess, 1997). 


\section{CAPÍTULO IV. RESULTADOS Y DISCUSIÓN}

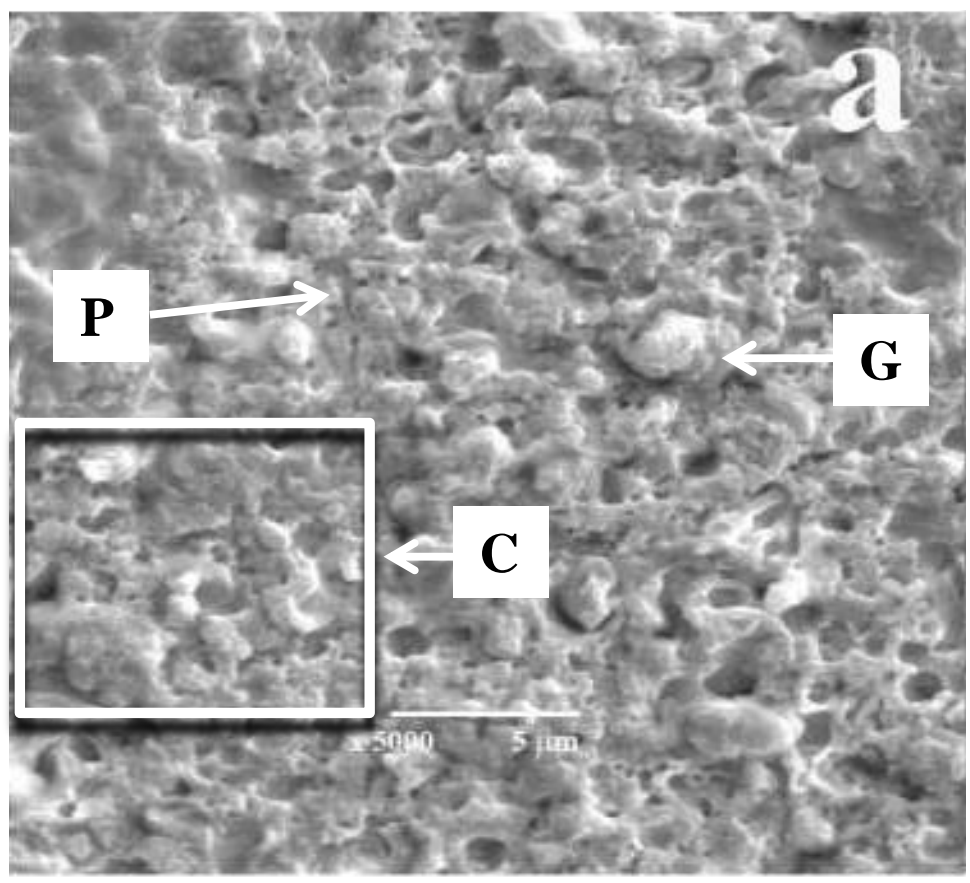

Figura 7a. Microestructura de la corteza del QC (5000x, barra corresponde a $5 \mathrm{m \mu})$ C. Cavidades; G. Grasa; P. Proteínas

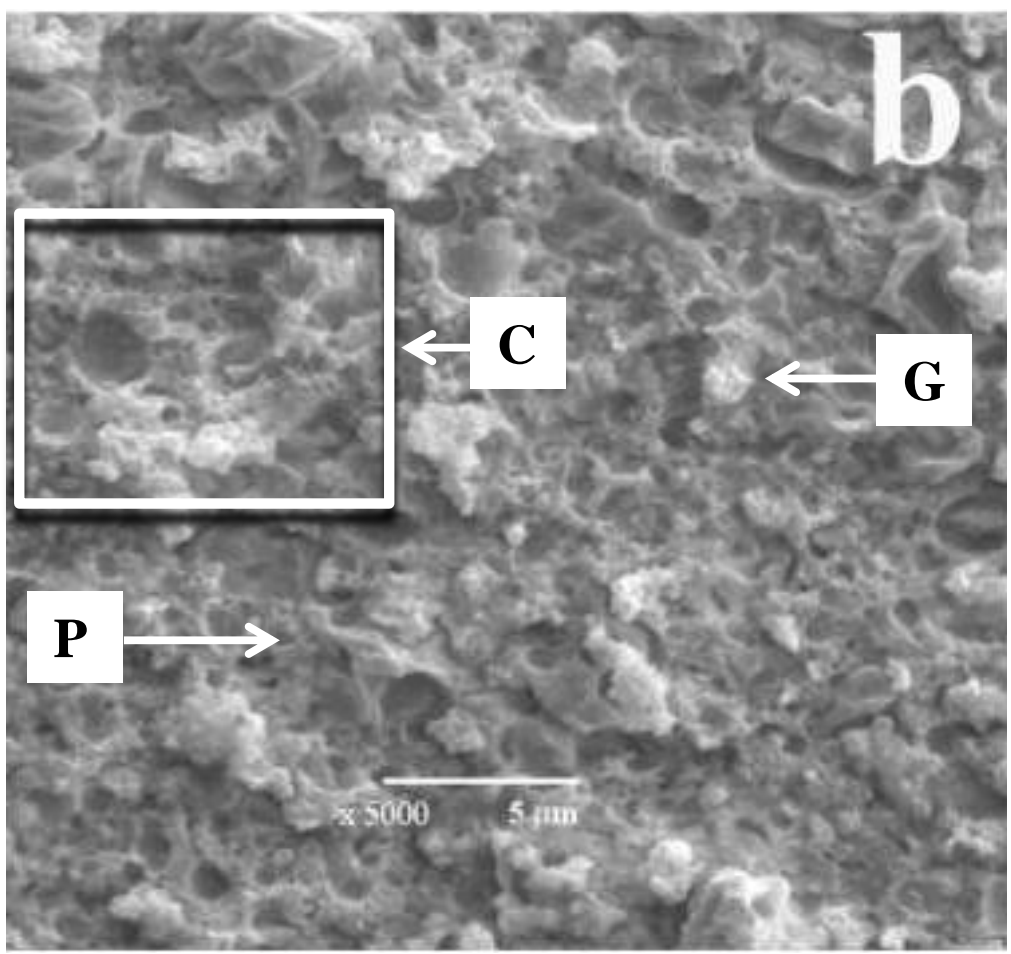

Figura 7b. Microestructura de la parte media del QC (5000x, barra corresponde a $5 \mathrm{~m} \mu)$ C. Cavidades; G. Grasa; P. Proteínas 


\section{CAPÍTULO IV. RESULTADOS Y DISCUSIÓN}

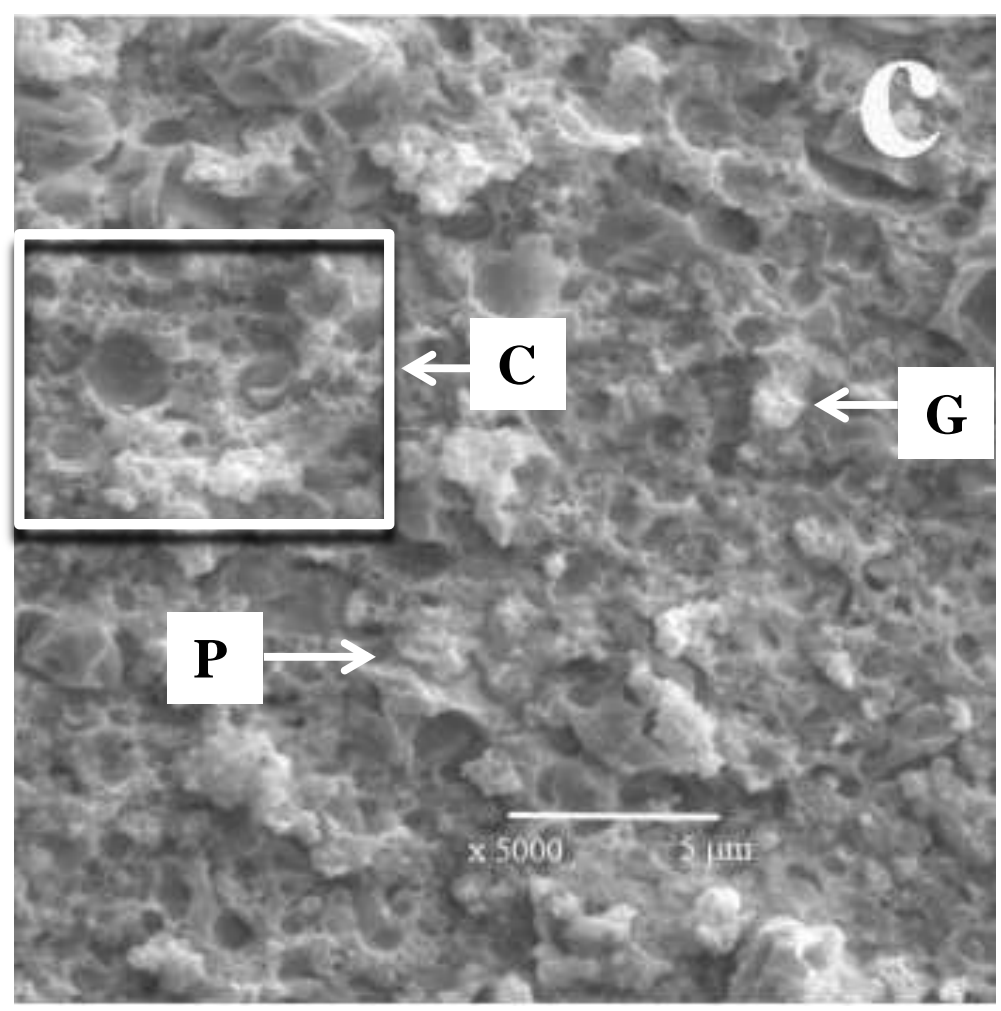

Figura 7c. Microestructura de la centro del QC (5000x, barra corresponde a $5 \mathrm{m \mu})$

Las micrografías obtenidas por SEM del QF (Figuras 8a, 8b y 8c) mostraron que la red de proteínas estaba más abierta y tenía cavidades más grandes que las del QC. Esto se debe al agua evaporada durante la preparación de la muestra para la observación en el microscopio electrónico de barrido. Estas cavidades pudieron haber contenido mayor cantidad de agua, lo que es consecuencia de la interacción de los EPS con la matriz de proteínas del queso (Hassan y cols. 2002; Guzel-Seydim y cols. 2005). Como se observa en las micrografías SEM (Figura $8 \mathrm{a}, 8 \mathrm{~b}$ y $8 \mathrm{c}$ ), las interacciones entre los EPS y la matriz de proteínas genera grandes espacios vacíos en el $\mathrm{QF}$, por lo que el polímero podría ser visto como parte de la red de la matriz de proteínas. Se observan también mayor cantidad de glóbulos de grasa en el QF que en el QC.

Debido al hecho de que el queso tipo Manchego es un queso de pasta prensada, se esperaba una microestructura con cavidades más pequeñas a lo largo de las tres distintas secciones de los quesos: el centro, la parte media y la superficie o corteza del queso. Las micrografías de los quesos mostraron que la estructura fue diferente en las secciones 


\section{CAPÍTULO IV. RESULTADOS Y DISCUSIÓN}

estudiadas: las cavidades en la matriz de proteínas resultaron más abiertas en el centro que en las secciones externas del queso, puesto que en el centro se conserva más humedad que en la corteza.

La comparación de las tres secciones del QF (Figura 8a, 8b y 8c) mostró que había una mayor concentración de EPS en el centro que en la corteza, lo cual indica que continuó la producción de los EPS durante la maduración; esta producción de EPS se facilita más en el centro donde se encuentra un mayor contenido de humedad y un ambiente anaeróbico más marcado que en las secciones externas, como en la corteza, donde la humedad es menor y hay una mayor concentración de oxígeno, lo que sugiere que el ambiente influye en el crecimiento de la bacterias y, por lo tanto, en la producción de EPS (Cerning, 1990).

La microestructura observada concuerda con los datos reportados en la Tabla 16, que revelan que en el QF se obtuvo una mayor retención de agua y grasa, lo cual produjo como consecuencia un aumento del rendimiento del queso, lo que se observa en las micrografías como una estructura más abierta y cavidades más grandes generadas por la evaporación del agua durante la preparación de la muestra para la microscopía. Estos resultados coinciden con lo reportado por Hassan y cols. (2002), quienes observaron por microscopía láser confocal, una estructura más abierta en el queso Feta elaborado con una cepa filante de Streptococcus thermophilus. Por su parte, Guzel-Seydim y cols. (2005) reportaron que los EPS se unen fuertemente al agua dentro de la matriz del QF y la retienen por más tiempo que en el QC. Este mismo efecto fue lo que se observamos en nuestro estudio durante la maduración de los quesos, donde el QF conservó más agua que el QC (Figura 6). 


\section{CAPÍTULO IV. RESULTADOS Y DISCUSIÓN}

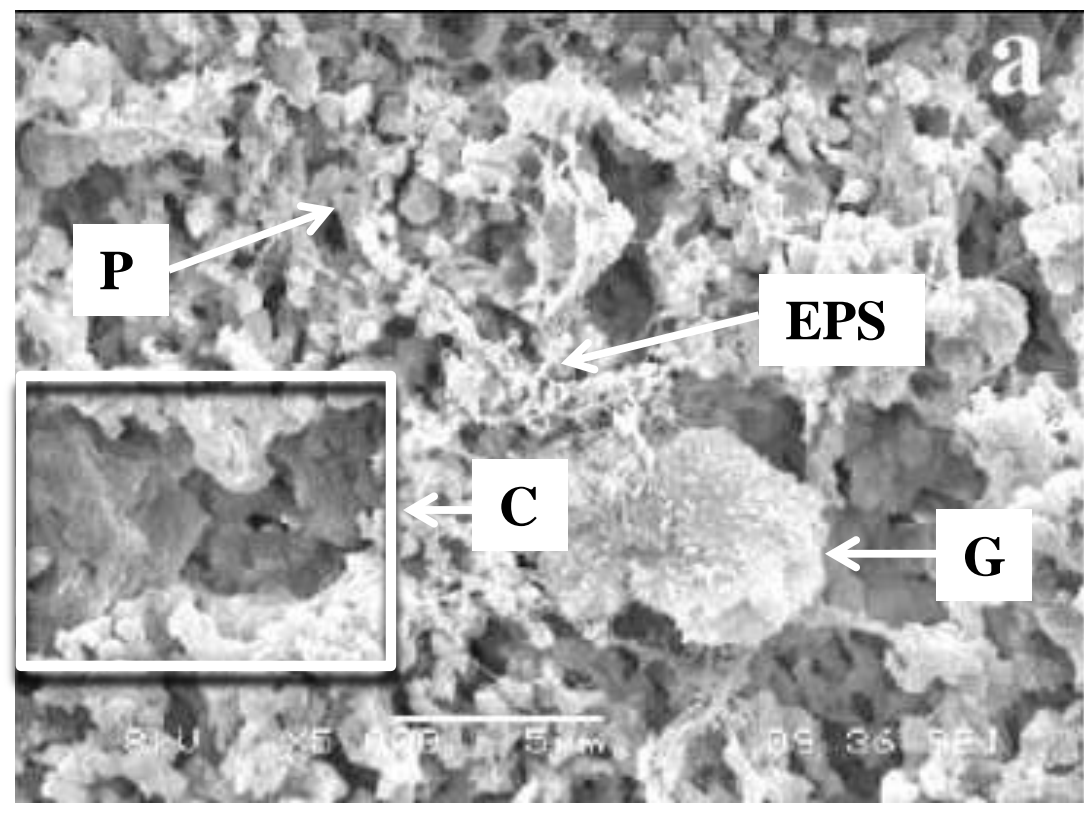

Figura 8a. Microestructuras de la corteza del QF (5000x, barra corresponde a $5 \mathrm{m \mu}$ ). EPS. Exopolisacáridos; C. Cavidades; G. Grasa; P. Proteínas.

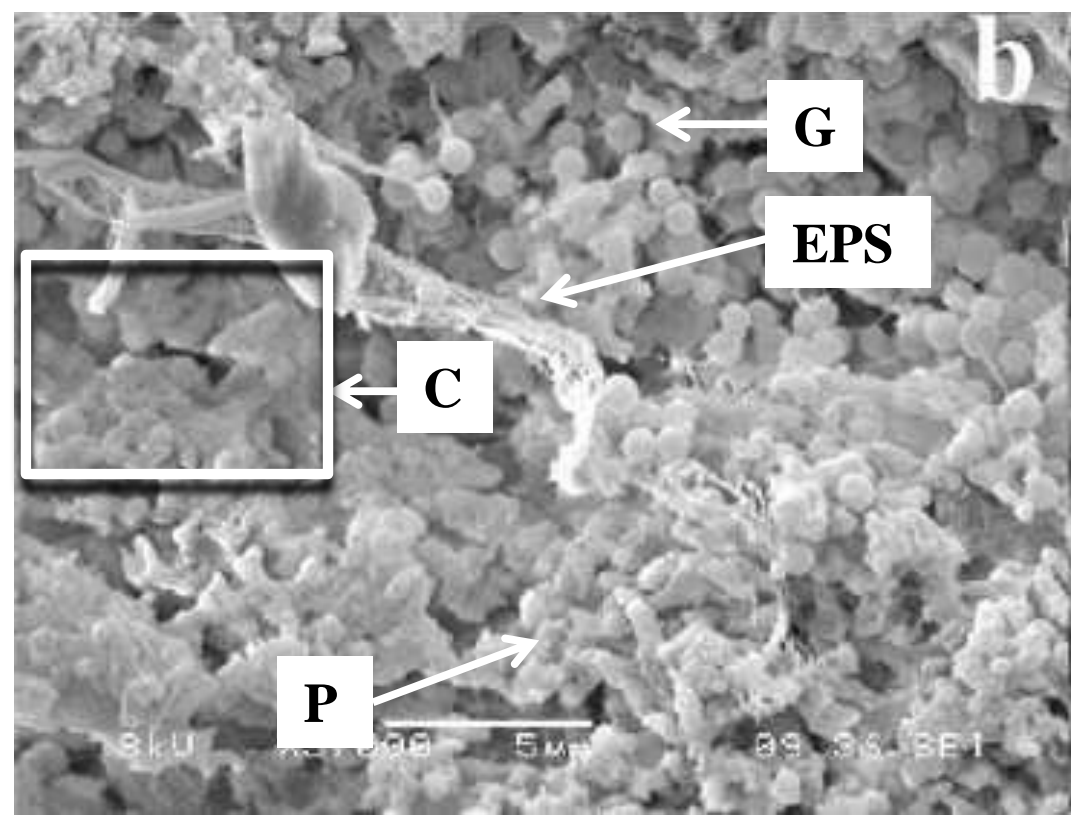

Figura 8b. Microestructuras de la parte media del QF (5000x, barra corresponde a $5 \mathrm{~m} \mu)$ EPS. Exopolisacáridos; C. Cavidades; G. Grasa; P. Proteínas 


\section{CAPÍTULO IV. RESULTADOS Y DISCUSIÓN}

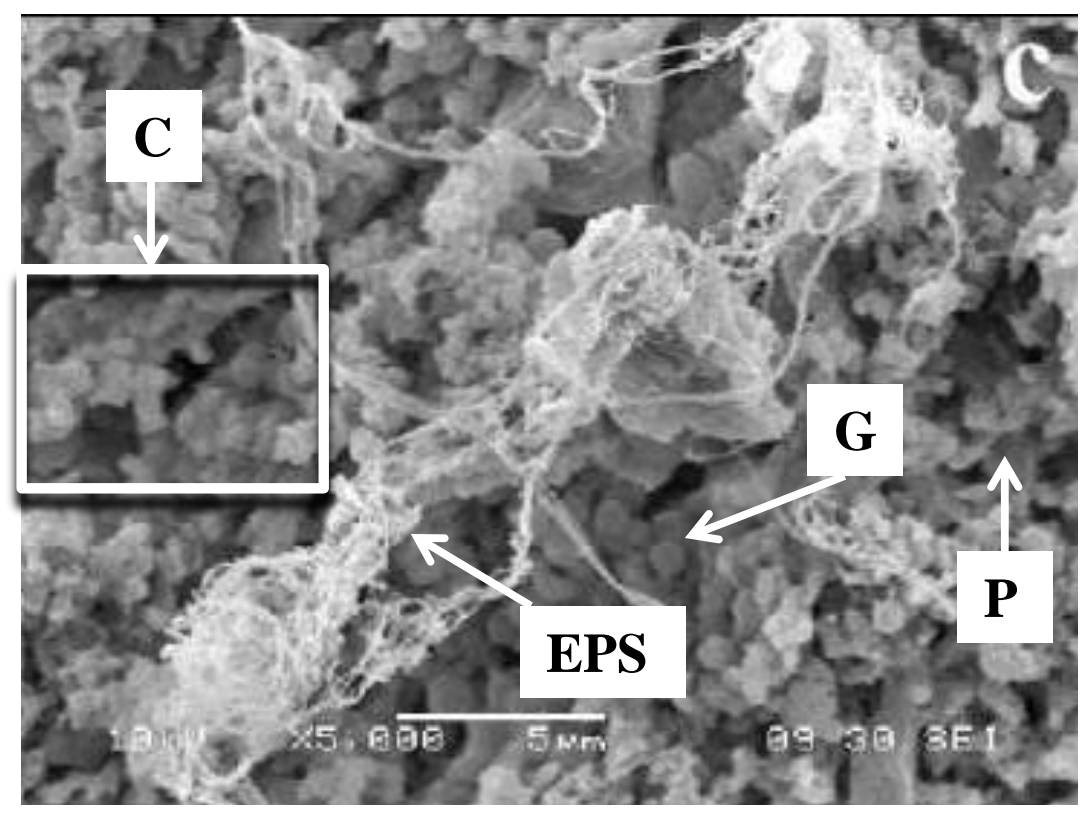

Figura 8c. Microestructuras del centro del QF (5000x, barra corresponde a $5 \mathrm{~m} \mu$ ) EPS. Exopolisacáridos; C. Cavidades; G. Grasa; P. Proteínas

\subsection{ANÁLISIS DEL PERFIL DE TEXTURA (APT)}

En la Figura 9 se muestran las curvas representativas del Análisis del Perfil de Textura (APT) obtenidas para ambos tipos de quesos. A partir de estas gráficas de fuerza-tiempo se calcularon los parámetros de: dureza, cohesividad, elasticidad y masticabilidad (Bourne, 1982). 


\section{CAPÍTULO IV. RESULTADOS Y DISCUSIÓN}

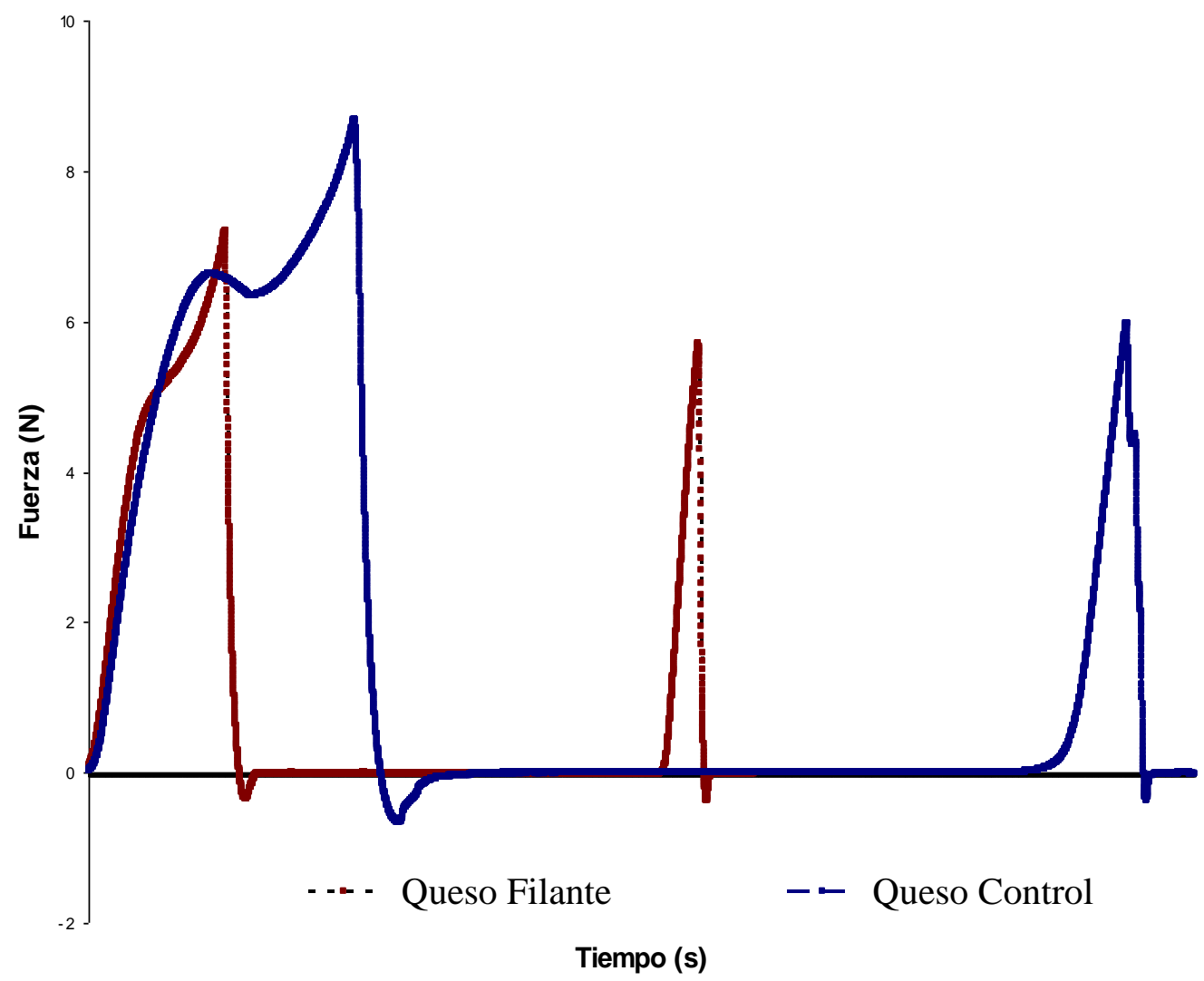

Figura 9. Curvas obtenidas por el Análisis del Perfil de Textura (APT) para el QC y el QF

La dureza y la elasticidad fueron significativamente menores en el QF en relación al QC, mientras que la cohesividad fue significativamente mayor; la masticabilidad no fue significativamente diferente entre ambos quesos (Tabla 18).

Tabla 18. Análisis del Perfil de Textura del QC y el QF

\begin{tabular}{|l|c|c|c|c|}
\hline & Dureza $(\mathbf{N}) *$ & Cohesividad $^{*}$ & $\begin{array}{c}\text { Elasticidad } \\
(\mathbf{m m}) *\end{array}$ & $\begin{array}{c}\text { Masticabilidad } \\
(\mathbf{N} \text { mm })\end{array}$ \\
\hline Queso Control & $8.67 \pm 0.26^{\mathrm{a}}$ & $0.15 \pm 0.02^{\mathrm{a}}$ & $6.90 \pm 0.42^{\mathrm{a}}$ & $8.96 \pm 1.21^{\mathrm{a}}$ \\
\hline Queso Filante & $6.73 \pm 0.47^{\mathrm{b}}$ & $0.18 \pm 0.01^{\mathrm{b}}$ & $6.24 \pm 0.38^{\mathrm{b}}$ & $7.66 \pm 1.14^{\mathrm{a}}$ \\
\hline
\end{tabular}

${ }^{\mathrm{a}, \mathrm{b}}$ Las letras de los subíndices muestran diferencias significativas $(\alpha<0.05)$ 


\section{CAPÍTULO IV. RESULTADOS Y DISCUSIÓN}

El mayor contenido de agua y de grasa en el QF (Tabla 16) produjo una estructura más abierta (Figuras 8a, 8b, 8c), dando lugar a un queso más suave, que fue también más cohesivo, pero menos elástico (Tabla 18). Un mayor contenido de grasa y de agua en los quesos tiende a debilitar la asociación entre proteínas, lo cual da lugar a un queso más suave (Jack, y cols., 1993; Tunick, y cols., 1993a, 1993b). Chen y cols., (1979) y Emmons y cols., (1980) han reportado que los quesos que contienen mayores contenidos de grasa en queso Cheddar se han relacionado también con una disminución en los valores de dureza y un aumento en los valores de masticabilidad (Chen y cols., 1979 y Emmons y cols., 1980).

A partir de una investigación hecha con queso Cheddar con diferentes contenidos de

grasa, Bryant y cols. (1995) establecieron que la microestructura de los quesos bajos en grasa estuvo conformada por una matriz de proteínas más compacta y con menos espacios abiertos, que de otra manera hubieran sido ocupados por glóbulos de grasa. Esto está asociado a una dureza mayor, aún cuando el contenido de humedad fuera más alto. Estos autores también reportan que la compleja microestructura abierta de los quesos analizados por SEM se perdió debido a una disminución en el contenido de grasa (Chen y cols., 1979; Emmons y cols., 1980; Bryant y cols., 1995).

El mismo efecto se puede observar en las Figuras 8a, 8b y 8c, en las que el QF presenta una estructura más abierta y en la que se observan los glóbulos de grasa dentro de la matriz de proteínas. Todos estos resultados también concuerdan con los datos reportados por LobatoCalleros y cols. (2001), quienes observaron que la reducción de grasa en el queso tipo Manchego produce un queso más duro al no tener las interrupciones propias de los glóbulos de grasa y, por lo tanto, se producen zonas más densas y compactas en la matriz de proteínas.

Por otra parte, es bien sabido que el aumento en el contenido de humedad en los quesos provoca un producto menos duro que los de humedad más baja, esto debido a las interacciones hidrofóbicas, que son de gran importancia para estabilizar la estructura de la matriz de proteínas; estas interacciones se ven debilitadas por la adsorción de agua en las proteínas (Tunick, y cols., 1991; Jack, y cols., 1992), lo que podría contribuir a una textura más suave en el QF.

Por otra parte, se esperaba una disminución en la cohesividad al aumentar la humedad y la grasa en el queso (Emmons, y cols., 1980), debido a que estos parámetros podían haber 


\section{CAPÍTULO IV. RESULTADOS Y DISCUSIÓN}

debilitado la estructura del queso; sin embargo no sucedió así, antes bien, la cohesividad resultó ser mayor en el QF gracias a las interacciones entre los EPS y las proteínas, como fue reportado por Domínguez-Soberanes y cols. (2001). Ellos sugirieron que las interacciones entre los EPS y las caseínas de la leche fermentada aumentaron la cohesividad. En un producto sólido, la cohesividad representa qué tanto su estructura resiste a la deformación y/o el desgarro, por lo que una mayor cohesividad en el QF, encontrada en esta investigación, sugiere que hay una interacción entre los EPS y la matriz de proteínas del queso, a pesar de contener un mayor contenido de grasa y de agua.

En cuanto a la elasticidad, los resultados indican que se obtuvo una elasticidad menor en el QF con respecto al QC. Bryant y cols. (1995) informaron que en el queso Cheddar la elasticidad aumentó con la disminución del contenido de grasa. Esto concuerda con Emmons y cols. (1980), que establecieron que el queso reducido en grasa tiende a ser más elástico. Si nos basamos únicamente en el contenido de grasa, los resultados encontrados estarían de acuerdo con lo reportado dichos investigadores (Emmons y cols., 1980; Bryant y cols., 1995). Sin embargo, no está claro cómo el contenido de humedad afecta la elasticidad, ya que se han reportado resultados tanto de incremento como de disminución en la elasticidad con respecto al contenido de humedad (Tunick, 1991).

La relación entre la composición del queso y el perfil de textura es muy compleja, y existen otros factores que también influyen en la textura del producto, como son las condiciones del proceso y la microbiota. Esto hace que sea difícil establecer una relación directa entre los componentes del queso y el perfil de la textura, como ha sido reportado por Van Hekken y cols. (2007) y Tunick y cols. (2007) en el queso Chihuahua, que es similar a la textura del queso mexicano tipo Manchego.

Para el atributo de masticabilidad no se encontraron diferencias significativas entre ambos quesos. 


\section{CAPÍTULO IV. RESULTADOS Y DISCUSIÓN}

\subsection{EVALUACIÓN SENSORIAL DE TEXTURA}

Para la prueba de análisis descriptivo cuantitativo se tomaron los mismos atributos que para el Análisis del Perfil de Textura (APT). La dureza y la cohesividad fueron significativamente menores en el QF, y la elasticidad resultó significativamente mayor a aquellas del QC. Los valores de masticabilidad de ambos quesos no mostraron diferencias significativas (Figura 10).

A pesar de que el Análisis de Perfil de Textura Instrumental (APT) está diseñado para simular la percepción sensorial de las propiedades físicas de los alimentos, la percepción humana de las propiedades de textura de los alimentos depende de otros factores más complejos que el análisis instrumental no puede considerar en conjunto en sus mediciones. Debido a esto, siempre es importante medir la percepción tanto instrumental como sensorial de la textura de un producto.

Al comparar los resultados obtenidos en el APT (Tabla 18) con los obtenidos en la evaluación sensorial (Figura 10) se observó que la dureza y la masticabilidad se midieron de forma similar por ambos métodos. En ambos casos fue mayor la dureza para el QC con respecto al QF; esto podría ser debido a que el QF tuvo un mayor contenido de humedad y de grasa, mientras que no hubo diferencia significativa para la masticabilidad en ambos quesos. La cohesividad y la elasticidad fueron percibidos por los jueces de una manera opuesta a la medición instrumental. 


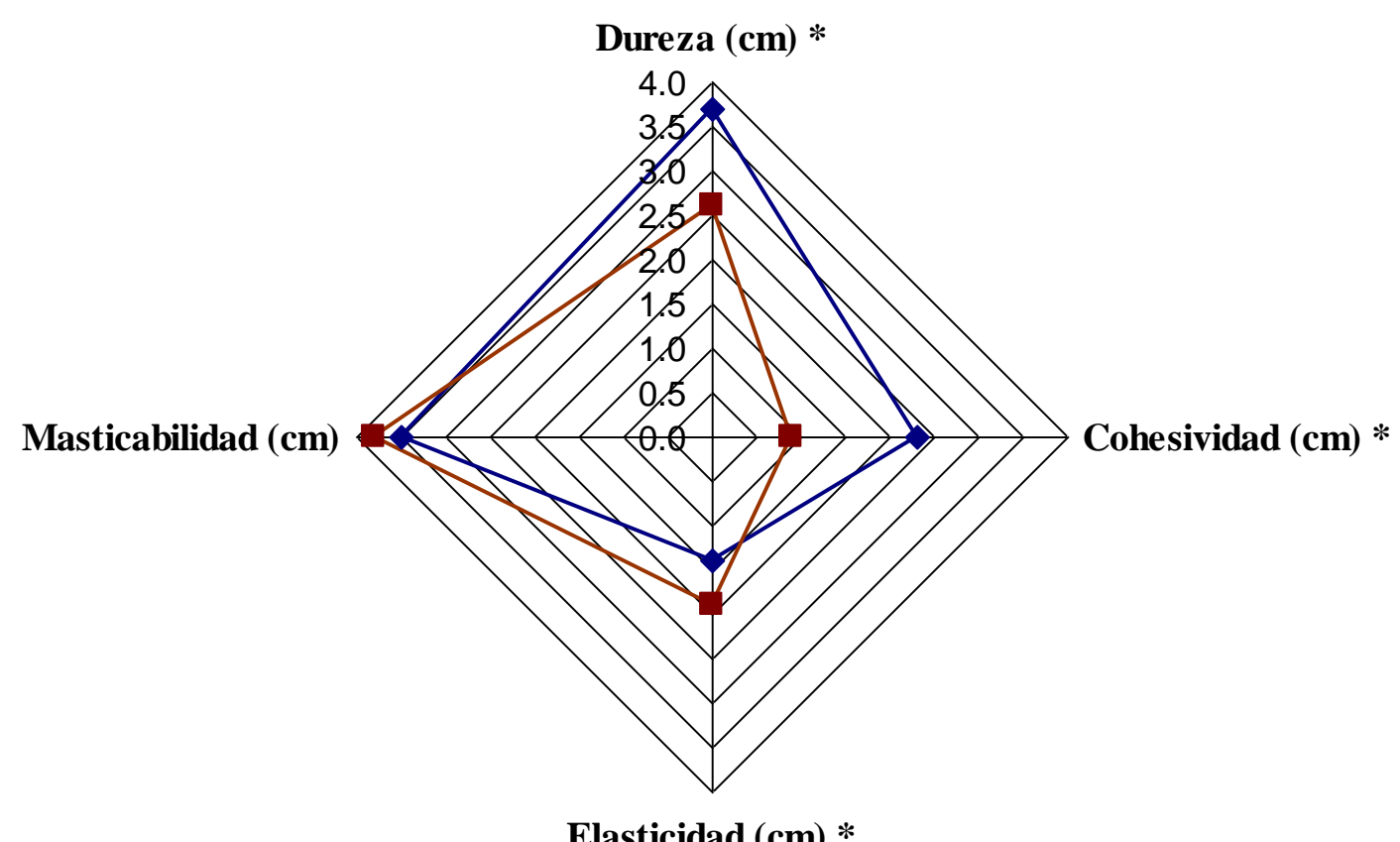

Elasticidad (cm) *

$\rightarrow \bullet$ Queso Control $\rightarrow-$ Queso Filante

Figure 10. Comparación del perfil de textura sensorial de los quesos

\subsection{RELACIÓN ENTRE LAS PROPIEDADES FISICOQUÍMICAS Y LAS PROPIEDADES DE TEXTURA DEL QUESO MEDIANTE ANÁLISIS DE COMPONENTES PRINCIPALES}

Algunos investigadores han observado que las propiedades de textura del queso se ven afectadas por su composición fisicoquímica, siendo las más importantes el contenido de grasa, de proteínas y de humedad, si bien la tecnología del procesamiento y la intensidad de la proteólisis también pueden afectar los resultados (Jaros y cols., 2001). La red de proteínas está formada por las alfa s1 y beta caseínas, cuyas cadenas helicoidales forman celdas que encierran los glóbulos de grasa, haciendo que la relación de grasa-proteína en la leche sea 


\section{CAPÍTULO IV. RESULTADOS Y DISCUSIÓN}

crítica, así como el contenido de minerales; un incremento en la materia grasa y contenido de agua debilitan la estructura proteica, mientras que una disminución de los mismos provoca un endurecimiento del queso.

Además, como se ha observado en el yogurt, las bacterias productoras de EPS ayudan a la retención de grasa y humedad en el queso, lo cual mejora la textura, ya que el uso de cepas productoras de EPS fortalece la red de proteínas, resultando una leche fermentada más firme por su capacidad de retener agua y que contribuye a disminuir la sinéresis (Cerning, 1995). Se ha observado en el queso, que la capacidad que tienen los EPS de retener agua y grasa mejora su textura, haciéndolo menos duro, y por lo tanto, menos cohesivo.

Para poder relacionar bien los atributos de textura, tanto sensoriales como instrumentales, con las propiedades fisicoquímicas de los quesos se procedió a hacer un Análisis de Componentes Principales (ACP).

El ACP es una técnica descriptiva que permite estudiar las relaciones que existen entre las variables cuantitativas, sin considerar a priori ninguna estructura, ni de variables, ni de individuos (Palm, 1998; Vizuata, 1998).

\subsubsection{Relación entre el Análisis de Perfil de Textura y la composición fisicoquímica de los quesos}

Se llevó a cabo un Análisis de Componentes Principales (ACP) a las propiedades de textura instrumental y a la composición fisicoquímica de los quesos con objeto de establecer las relaciones principales entre éstas y estudiar la distribución de los quesos en este espacio bidimensional.

A través de ésta técnica estadística se relacionaron los atributos de textura (dureza, cohesividad, elasticidad y masticabilidad) y las propiedades fisicoquímicas (humedad, grasa y proteínas) con la finalidad de indagar cómo se modifica la textura del queso cuando varía su composición.

El primer componente principal explicó el $70.32 \%$ de la varianza total de los quesos (Tabla 19) y fue descrito por las propiedades de dureza y elasticidad correlacionadas positivamente entre sí, y negativamente con la cohesividad, humedad y contenido de grasa de 


\section{CAPÍTULO IV. RESULTADOS Y DISCUSIÓN}

los quesos (Figura 11). El segundo componente principal explicó el $18.26 \%$ de la varianza total de los quesos y fue descrito por la propiedad de masticabilidad correlacionada positivamente con el contenido de proteína. En conjunto, los dos componentes explicaron el $88.59 \%$ de la varianza de los quesos.

Tabla 19. ACP de la relación entre el APT y composición fisicoquímica de los quesos

\begin{tabular}{|c|c|c|c|}
\hline $\begin{array}{c}\text { Número de } \\
\text { Componente }\end{array}$ & Valores propios & $\begin{array}{c}\text { Porcentaje de } \\
\text { Varianza }\end{array}$ & $\begin{array}{c}\text { Porcentaje } \\
\text { Acumulado }\end{array}$ \\
\hline 1 & $\mathbf{4 . 9 2 3}$ & $\mathbf{7 0 . 3 2 9}$ & $\mathbf{7 0 . 3 2 9}$ \\
\hline 2 & $\mathbf{1 . 2 7 8 5 7}$ & $\mathbf{1 8 . 2 6 5}$ & $\mathbf{8 8 . 5 9 4}$ \\
\hline
\end{tabular}

En la Tabla 20 se muestra el peso de cada uno de los componentes. Se observa que el primer componente está dado en su mayoría por la dureza y la elasticidad, y está correlacionado negativamente con la cohesividad, la humedad y la grasa. El segundo componente principal fue descrito por la masticabilidad y el contenido de proteína de los quesos, los cuales estuvieron correlacionados positivamente.

Tabla 20. Peso de los componentes del ACP de la relación entre el APT y la composición fisicoquímica de los quesos

\begin{tabular}{|l|c|c|}
\hline & Componente 1 & Componente 2 \\
\hline Dureza & $\mathbf{0 . 4 4 3 6 2 4}$ & 0.0312047 \\
\hline Cohesividad & $\mathbf{- 0 . 4 0 5 5 5 5}$ & 0.357018 \\
\hline Elasticidad & $\mathbf{0 . 3 9 9 9 1 7}$ & -0.0659374 \\
\hline Masticabilidad & 0.308622 & $\mathbf{0 . 4 3 9 7 6 2}$ \\
\hline \% Humedad & -0.442939 & -0.123884 \\
\hline \% Grasa & -0.409597 & -0.188383 \\
\hline \% Proteína & -0.139919 & $\mathbf{0 . 7 8 9 2 9 8}$ \\
\hline
\end{tabular}

Los dos componentes principales distinguieron claramente a los dos quesos en términos de su composición y sus propiedades de textura instrumental (Figura 11). La posición del QF respecto al QC en el espacio bidimensional permite establecer que la cepa filante incorporada al queso tipo Manchego afectó tanto su composición fisicoquímica, como sus 


\section{CAPÍTULO IV. RESULTADOS Y DISCUSIÓN}

propiedades de textura. Así, el QF mostró valores de dureza y elasticidad bajos y valores de cohesividad elevados, los cuales se correlacionaron con altos contenidos de humedad y de grasa. En contraste el QC presentó valores elevados de dureza y elasticidad relacionados con bajos contenidos de humedad y de grasa. La masticabilidad de los quesos se correlacionó con su contenido de proteína, siendo éste último mayor en el QC.

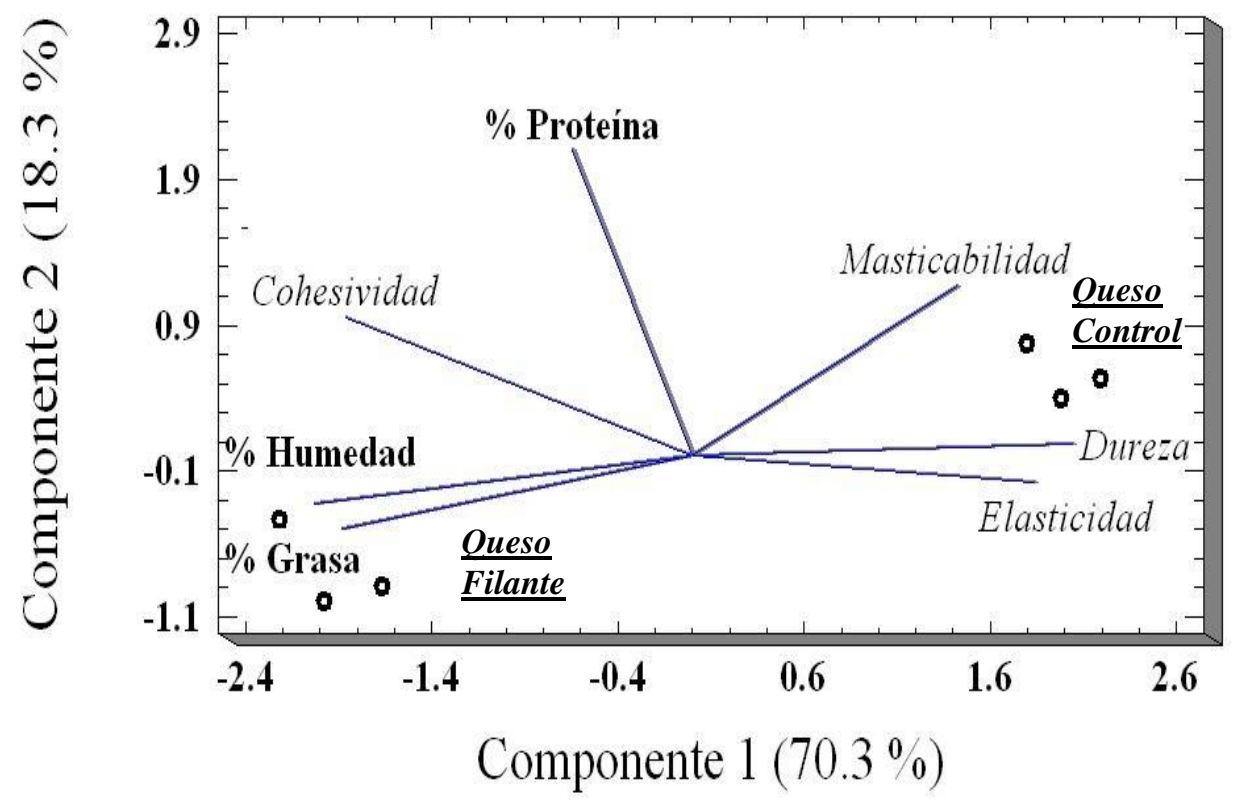

Figura 11. ACP de la textura instrumental y composición fisicoquímica del QC y del QF.

Los resultados expuestos indican que ciertas modificaciones en los contenidos de humedad y de grasa en el queso tipo Manchego, como consecuencia del uso de la cepa filante, fueron los principales factores responsables de la variación en sus propiedades texturales, en particular de la dureza y la elasticidad. Los contenidos mayores contenidos de humedad y de grasa contribuyeron a la formación de un queso suave y menos elástico. 


\section{CAPÍTULO IV. RESULTADOS Y DISCUSIÓN}

\subsubsection{Relación entre la Evaluación Sensorial de textura y las propiedades fisicoquímicas de los quesos}

Se realizó un ACP para estudiar la relación existente entre los atributos de textura sensorial y la composición fisicoquímica del QC y del QF. El primer componente explicó el 72.21\% de la varianza total y el segundo componente explicó el $20.3 \%$ de la varianza total. El total acumulado para estos dos componentes explicó el $92.53 \%$ (Tabla 21).

Tabla 21. ACP de la relación entre la Evaluación Sensorial de textura y la composición fisicoquímica de los quesos

\begin{tabular}{|c|c|c|c|}
\hline $\begin{array}{c}\text { Número de } \\
\text { Componente }\end{array}$ & Valores propios & Porcentaje de Varianza & $\begin{array}{c}\text { Porcentaje } \\
\text { Acumulado }\end{array}$ \\
\hline 1 & $\mathbf{5 . 0 5 4 9 1}$ & $\mathbf{7 2 . 2 1 3}$ & $\mathbf{7 2 . 2 1 3}$ \\
\hline 2 & $\mathbf{1 . 4 2 2 3 2}$ & $\mathbf{2 0 . 3 1 9}$ & $\mathbf{9 2 . 5 3 2}$ \\
\hline
\end{tabular}

El primer componente principal fue descrito por la dureza, correlacionada negativamente con la elasticidad, la masticablidad y los contenidos de grasa y de humedad de los quesos. El segundo componente principal fue descrito por la cohesividad correlacionada positivamente con el contenido de proteína (Tabla 22).

Tabla 22. Peso de los componentes del ACP de la relación entre la Evaluación Sensorial de Textura y composición fisicoquímica de los quesos

\begin{tabular}{|l|c|c|}
\hline & Componente 1 & Componente 2 \\
\hline Dureza & $\mathbf{0 . 4 1 4 2 8}$ & -0.293438 \\
\hline Cohesividad & 0.331992 & $\mathbf{0 . 3 3 5 5 4 6}$ \\
\hline Elasticidad & $\mathbf{- 0 . 4 0 3 0 4 6}$ & -0.313049 \\
\hline Masticabilidad & $\mathbf{- 0 . 4 4 1 4 4 5}$ & 0.0838147 \\
\hline \% Humedad & $\mathbf{- 0 . 4 3 9 8 6 1}$ & 0.0961091 \\
\hline \% Grasa & $\mathbf{- 0 . 4 0 8 5 2 1}$ & 0.0461864 \\
\hline \% Proteína & -0.0215858 & $\mathbf{0 . 8 2 7 5 9 2}$ \\
\hline
\end{tabular}




\section{CAPÍTULO IV. RESULTADOS Y DISCUSIÓN}

De acuerdo a la posición de los quesos en el espacio bidimensional, se puede inferir que el QF fue percibido como más elástico y masticable, pero menos duro y cohesivo que el QC (Figura 12). Las propiedades texturales del QF mencionadas estuvieron relacionadas con sus contenidos relativamente elevados de grasa y humedad. Las propiedades texturales del QC fueron las opuestas a las descritas para el QF.

Al comparar los resultados de los ACP efectuados a los datos de composición química de los quesos con sus propiedades texturales instrumentales y sensoriales, puede observarse que la única propiedad textural que siguió la misma tendencia en ambos casos fue la dureza, estando correlacionada negativamente con los contenidos de grasa y de humedad del queso. En oposición, las propiedades de elasticidad, cohesividad y masticabilidad fueron percibidas por el panel de distinta manera a como fueron medidas con el texturómetro. Con base en lo expuesto, la dureza pudiera ser seleccionada como la característica textural que puede ser evaluada ya sea sensorial o instrumentalmente, y se puede por tanto emplear para la discriminación de quesos tipo Manchego con distinta composición química.

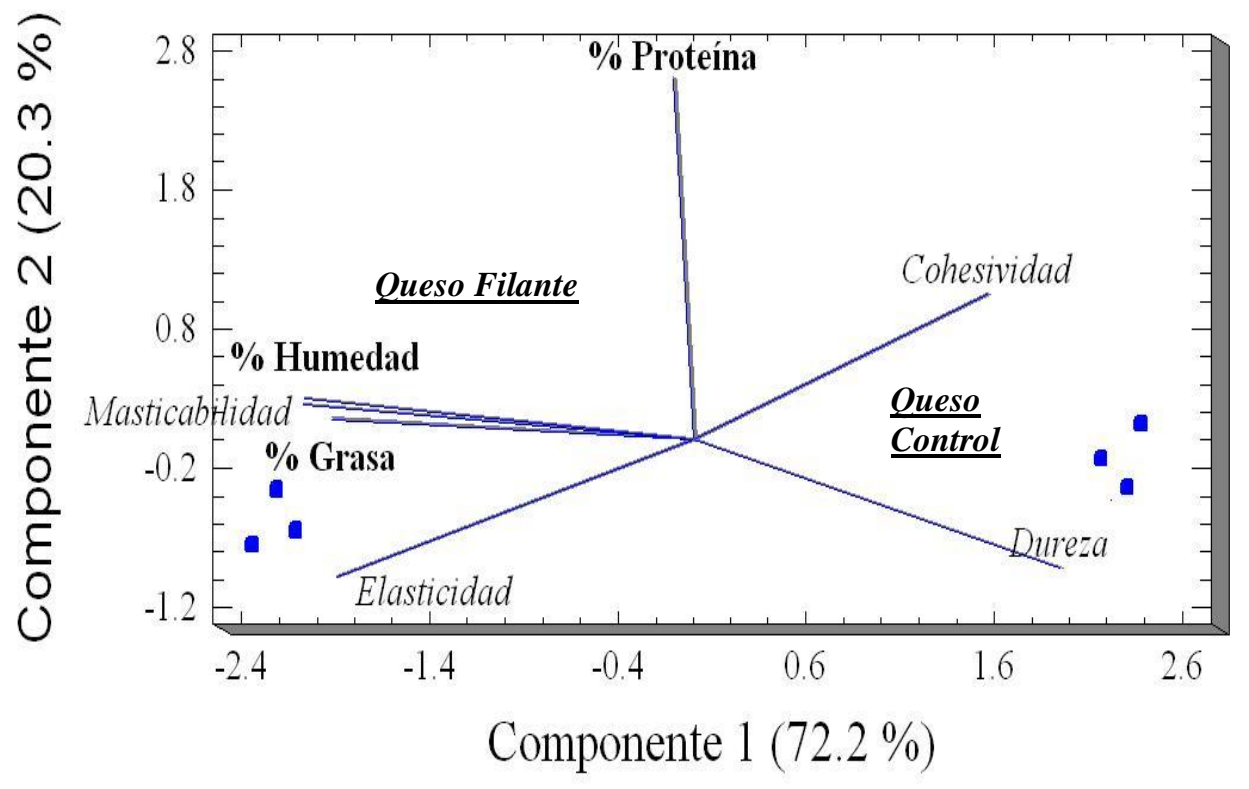

Figura 12. Análisis de componentes principales de textura sensorial y propiedades fisicoquímicas de queso control y queso filante. 


\section{CAPÍTULO IV. RESULTADOS Y DISCUSIÓN}

Los resultados expuestos indican que la textura del queso no fue percibida por los sentidos de igual modo que por el analizador de textura instrumental, aún cuando este último fue diseñado para imitar la percepción de textura por los jueces (Marshall y cols., 1990 y Jack y cols., 1993). El texturómetro puede cuantificar simultáneamente una serie de propiedades de textura, si bien se ha demostrado que solamente la dureza se relaciona bien con los datos obtenidos del análisis sensorial, mientras que los demás atributos de textura son muy diferentes a los detectados por este instrumento (Marshall, 1990; Jack, y cols., 1992). 


\section{CAPÍTULO V. CONCLUSIONES}




\section{CONCLUSIONES}

- El uso de la cepa productora de exopolisacáridos de Streptococcus thermophilus SY102 utilizada en la elaboración del queso tipo Manchego, influyó en aumentos significativos en la retención de humedad y grasa, y, por lo tanto, en un mayor rendimiento del mismo, debido a la interacción de los EPS en la red de proteínas formada.

- La Microscopía Electrónica de Barrido (SEM) mostró que los EPS se unen a la matriz de proteína del queso, a los microorganismos y a los glóbulos de grasa, dando lugar a una estructura más abierta generada por la retención de agua y grasa. Por otra parte, las interacciones entre EPS y el agua fueron lo suficientemente fuertes como para retener la humedad durante la maduración del queso.

- El contenido más alto de humedad y de grasa obtenido en el queso filante se reflejó en un cambio en las características de textura tanto instrumentales como sensoriales, de las cuales, la dureza es la más importante en cuanto a la aceptabilidad del queso.

- En el Análisis del Perfil de Textura (APT), el queso elaborado con la cepa filante resultó menos duro, menos elástico y más cohesivo comparado con el queso control; en masticabilidad no se encontraron diferencias.

- Los cambios en las características de textura se relacionaron con los cambios en la composición de queso: se produjo una mayor dureza cuando la humedad y la grasa disminuyeron, mientras que la elasticidad disminuyó cuando la grasa aumentó. Las interacciones de los EPS con la matriz de proteína del queso tuvieron una influencia en una mayor cohesividad en el queso filante. 
- En la Evaluación Sensorial de Textura, el queso elaborado con la cepa filante, resultó menos duro, menos cohesivo y más elastico que el queso control, mientras que no se encontraron diferencias en la masticabilidad.

- La composición de los quesos influyó también en las características sensoriales, dando lugar a una textura más suave en el queso filante que en el queso control. Otros atributos de textura que se percibieron de forma diferente por los panelistas y el texturómetro fueron la cohesividad y la elasticidad. 


\section{CAPÍTULO VI. BIBLIOGRAFÍA}




\section{CAPÍTULO VI. BIBLIOGRAFÍA}

\section{BIBLIOGRAFÍA}

1. Abbad-Andaloussi, S., Talbaoui, H., Marczak, R. and Bonaly, R. (1995). Isolation and characterization of exocellular polysaccharides produced by Bifidobacterium longum. Applied Microbiology and Biotechnology 43:995-1000.

2. Amiot, J. (1991). Ciencia y tecnología de la leche. Zaragoza, España: Acribia. pp. 278 280.

3. Anzaldua-Morales, A. y Vernon, E. J. (1982). Design of standard scales for some textural properties of Mexican foodstuffs. Advances in Rheology. 4:132-142.

4. Anzaldúa-Morales, A. (1994). La evaluación sensorial de los alimentos en la teoría y la práctica. Zaragoza, España: Acribia. pp. 24 - 41, 96 - 111.

5. Ayala-Hernández, I., Goff, H. D. y Corredig, M. (2008). Interactions Between Milk Proteins and Exopolysaccharides Produced by Lactococcus lactis Observed by Scanning Electron Microscopy. Journal of Dairy Science. 91:2583-2590

6. Battistotti, B., Botazzi, V., Picinardi, A. y Volpato, G. (1983). Quesos del mundo. Barcelona, España: Elfos.

7. Bayer, M. (1994). Biophysical and structural aspects of the bacterial capsule. Features. 60: 192

8. Boels, I. C., van Kranenburg, R., Hugenholtz, J., Kleerebezem, M. y de Vos, W. M. (2001). Sugar catabolism and its impact on the biosynthesis and engineering of exopolysaccharide production in lactic acid bacteria. International Dairy Journal. 11(9):723-732.

9. Bérodier, F., Lavanchy, P., Zannoni M., Casals, J., Herrero, L. y Adamo, C. (1996). Guía para la evaluación olfato-gustativa de los quesos de pasta dura o semidura. INRA.

10. Botazzi, V. (1999). Aspetti biotecnologici del Parmiggiano Reggiano. Piacenza, Italia: Mofin s.r.l. pp. 13-15.

11. Bourne, M.C. (1982). Food Texture and Viscosity: Concept and Measurement. New York: Academic Press. pp 110-113, 247-279

12. Bourne, M.C. (1976). Texture of Fruits and vegetables. En Rheology and Texrure in Food Quality, (J.M. de Man, P.W. Voiy, V.F. Rasper y D.V. Stanley, eds.). pp 244-274. The AVI Publishing Co, Westpot, CT. 


\section{CAPÍTULO VI. BIBLIOGRAFÍA}

13. Brennan, J.G. (1980). Food texture measurement. In King R.D. (ed.). Developments in Food Analysis Techniques. Applied Science. Essex. UK. Vol.2.

14. Broadbent, J.R., McMahon, D.J., Oberg, C.J. y Welker, D.L. (2001). Use of Exopolysaccharide-Producing Cultures to Improve the Functionality of Low Fat Cheese. International Dairy Journal. 11, 433-439.

15. Bryant, A., Ustunol, Z. y Steffe, J. (1995). Texture of Cheddar Cheese as Influenced by Fat Reduction. Journal of Food Science. 60, 1216-1219, 1236.

16. Bubb, W.A., Urashima, T., Fujiwara, E., Shinnai, T. y Ariaga, H. (1997). Structural characterisation of the exocellular polysaccharide produced by Streptococcus thermophilus OR 901. Carbohydrate Research. 301:41-50.

17. Camacho-Vera, J., (1983), Caracterización del queso asadero. Tesis de licenciatura. UACh-DIS, Chapingo, México

18. Cenzano, I. (1992). Los quesos. Madrid. España: Editorial Mundi-Prensa y AMV Ediciones. pág. 11, 43.

19. Cerning, J., (1990). Exocellular polysaccharides produced by lactic acid bacteria, FEMS Microbiology Review. 87:113-130.

20. Cerning, J., (1995). Production of exopolysaccharides by lactic acid bacteria and dairy propionibacteria. Lait. 75:463-472.

21. Cerning, J., Bouillanne, C., Desmazeaud, M. J., y Landan, M. (1986). Isolation and characterization of exocellular polysaccharide produced by Lactobacillus bulgaricus. Biotechnology Letters. 8: 625.

22. Cervantes-Escoto, F., Villegas de Gante, A., Cesin-Vargas, A. y Espinosa-Ortega, A. (2008). Los quesos mexicanos genuinos: Patrimonio cultural que debe rescatarse. China: Mundiprensa. pp. 36-37, 88-89.

23. Chabot, S., Yu, H., De Léséleuc, L., Cloutier, D., van Calsteren, M.R., Lessard, M., Roy, D., Lacroix, M. y Oth, D. (2001). Exopolysaccharide from Lactobacillus Rhamnosus RW-9595M stimulate TNF, IL-6 abd IL-12 in human and mouse cultured inmunocompetent cell, and IFN-g in mouse splenocytes. Lait. 81:683-697.

24. Champagne, C.P., Barrette, J., Roy, D. y Rodrigue, N. (2006), Fresh Cheesemilk Formulation Fermented by a Combination of Freeze-Dried Citrate-Positive Cultures and Exopolysaccharide-Producing Lactobacilli with Liquid Lactococcal Starter. Food Research International. 39:651-659. 


\section{CAPÍTULO VI. BIBLIOGRAFÍA}

25. Chen, A.H., Larkin, J.W., Clark, C.J. y Irwin, W.E. (1979). Textural Analysis of Cheese. Journal of Dairy Science. 62:901-907.

26. Chervaux, C., Ehrlich, S. D. y Maguin, E. (2000). Physiological study of Lactobacillus delbrueckii subsp bulgaricus strains in a novel chemically defined medium. Applied and Environmental Microbiology. 66(12):5306-5311.

27. Codex Alimentarius, OMS y FAO. (2007). Leche y productos lácteos. Roma. Recuperada el 15 de Mayo de 2012, de www.lactodata.com/lactodata/docs/lib/codex_leche_y_productos lacteos.pdf.

28. Cogan, T.M. (2000). Cheese microbiology. En Fundamentals of Cheese Science. Eds: P.F. Fox, T. Ginee, T.M. Cogan y P.L.H. McSweeny. Gaithersburg: Aspen publishers.

29. Costa, N.E., O'Callaghan, D.J., Mateo, M.J., Chaurin, V., Castillo, M.J., Hannon, A. P. McSweeney, L.H. y Beresford, T.P. (2012). Influence of an exopolysaccharide produced by a starter on milk coagulation and curd syneresis. International Dairy Journal. 22: 4857.

30. Costell, E. y Durán, L. (1981). El análisis sensorial en el control de calidad de los alimentos. Introducción. Revista Agroquímica y Tecnología Alimentaria. 21(1): 1- 10.

31. Covarrubias, P.M., Vega, L.S. y Flores, P.N. (1996). Cap. 8: Análisis de queso. En Métodos de análisis de leche y derivados. (pp. 409-419). México: UAM, Xochimilco.

32. Dal Bello, F.D., Walter, J., Hertel, C. y Hemmes, W.P. (2001). In Vitro study of prebiotic properties of levan-type exopolysaccharides from Lactobacilli and nondigestible carbohydrates using denaturing gradient gel electrophoresis. System Applied Microbiology. 24:232-237.

33. Dassy, B., Strigfellow, W. T., Lieb, M. y Foumier, J. M., (1991). Production of type 5 capsular polysaccharide by Staphylococcus aureus grown in a semisynthetic medium. Journal Genetics Microbiology. 137:1155.

34. De Alba, L.A., Staff, C., Richter, R.L. y Dill, C,W. (1991). Mexican Asadero cheese: a surrey of its composition. Cultured Dairy Products Journal. 26: 11 - 12

35. De la Fuente, M.A. y Juárez, M. (2001). Los quesos: una fuente de nutrientes. Alimentos Nutrición Salud. 8:75-83.

36. De Vuyst, L. y Degeest, B. (1999). Heteropolysaccarides from lactic acid bacteria. FEMS Microbiology Review. 23:153-177. 


\section{CAPÍTULO VI. BIBLIOGRAFÍA}

37. De Vuyst, L., De Vin, F., Vaningelgem, F. y Degeest, B. (2001). Recent developments in the biosynthesis and applications of heteropolysaccharides from lactic acid bacteria. International Dairy Journal. 11:687-708.

38. Degeest, B., Janssens, B. y De Vuyst, L. (2001a). Exopolysaccharide (EPS) biosynthesis by Lactobacillus sakei 0-1: Production kinetics, enzyme activities and EPS yields. Journal of Applied Microbiology. 91:470-477.

39. Degeest, B., Vaningelgem, F. y De Vuyst, L. (2001b). Microbial physiology, fermentation kinetics and process engineering of heteropolysaccharides production by lactic acid bacteria. International Dairy Journal. 11:747-758.

40. Degeest, B. y De Vuyst, L. (2002). Effect of medium composition and temperature and $\mathrm{pH}$ changes on exopolysaccharide yields and stability during Streptococcus thermophilus LY03 fermentations. International Journal of Food Microbiology. 79(3):161-174.

41. Dickinson, E. (1995). Food polysaccharides and their applicatios. New York: Alistair M. Stephen. Marcel Dekker Inc. pp. 509-510.

42. Dickinson, E. (1998). Stability and rheological implications of electrostatic milk proteinpolysaccharide interactions. Trend in Food Science and Technology. 9:347-354.

43. Doco, T., Wieruszeski, J.M. y Fournet, B. (1990). Structure o fan exocellular polysaccharide produced by Streptococcus thermophilus. Carbohydrate Reserach. 198:313-321.

44. Dominguez-Soberanes, J., García-Garibay, M., Casas-Alencáster, N.B. y MartínezPadilla, L.P. (2001). Instrumental Texture of Set and Stirred Fermented Milk. Effect of a Ropy Strain of Lactobacillus delbrueckii subsp. bulgaricus and an Enriched Substrate. Journal of Texture Studies. 32:205-217.

45. Duboc, P. y Mollet, B. (2001). Applications of exopolysaccharides in dairy industry. International Dairy Journal. 11:759-768.

46. Duchesne, I. y Daniel, G (1999). The ultrastructure of wood fiber surfaces as shown by a variety of microscopic methods - a review. Nordic Pulp and Paper Research Journal. 14(2):129-139.

47. Eckhof-Stark, N. (1983). El mundo del queso. (2a Ed.). Revista geografía universal. México.

48. Emmons, D.B., Kalab, M., Larmond, E. y Lowrie, R.J. (1980). Milk Gel Structure X. Texture and Microstructure in Cheddar Cheese Made from Whole Milk and Homogenized Low-Fat Milk. Journal of Texture Studies. 11:15-34. 


\section{CAPÍTULO VI. BIBLIOGRAFÍA}

49. Espinosa, T., Villegas, A., Gómez, G., Bruz, G. y Hernández, A. (2006). La agroindustria láctea en el Valle de México: un ensayo de categorización. Técnica Pecuaria, 44(2):182 - 192.

50. Faber, E.J., van den Haak, M.J., Kamerling, J.P. y Vliegenthart, J.F.G. (2001). Structure of the exopolysaccharide produced by Streptococcus thermophilus S3. Carbohydrate Research. 331:173-182.

51. Fox, F.P., Guinee, T.P., Cogan, T.M. y McSweeney, P.L.H. (2000). Fundamentals of cheese sciense. Caithersburg Maryland: Aspec Publishers. Inc.

52. Fox, P.F., O’Connor, T.P., McSweeney, P.L.H., Guinee, T.P. y O’Brien, N.M. (1996). Chesse: physical, biochemical and nutritionals aspects. Advances in Food and Nutritional Research. 39:163-328.

53. Fox, P.F. y McSweeney, P.L.H. (1998). Dairy Chemistry and Biochemistry. London: Blackie Academic and Professional.

54. Fox, P.F., Fuquay, J.W. y Roginski, H. (2003). Cheese en Encyclopedia of Dairy sciences. Vol. 1. Elsevier Science Ltd. Londres: Academic press. pp. 255, 260-261.

55. Gancel, F. y Novel, G. (1994a). Exopolysaccharide production by Streptococcus salivarius ssp. thermophilus cultures. 1. Conditions of production. Journal of Dairy Science. 70:325-328.

56. Gancel, F., y Novel, G. (1994b). Exopolysaccharide production by Streptococcus salivarius ssp. thermophilus cultures. 2. Distint modes of polymer production and degradation among clonal variants. Journal of Dairy Science. 77:689-695.

57. García-Garibay, M. y Marshall, V.M.E. (1991). Polymer production by Lactobacillus delbrueckii ssp. bulgaricus. Journal of Applied Bacteriology. 70:325-328.

58. García-Garibay, M., Revah, M. y Gómez-Ruíz, L. (1993). Biotecnología Alimentaria. México: Limusa, Noriega Editores. pp. 179 - 185.

59. García-Islas, V. (2006). Aislamiento de microorganismos con mayor actividad lipolítica del queso Cotija. Tesis de licenciatura. Facultad de Química. UNAM. México.

60. Gruter, M., Leeflang, B. R. Kuiper, J. Kamerling, P. and Vliegenthart, F. G. (1993). Structural characterisation of the exopolysaccharide produced by Lactobacillus delbrueckii subspecies bulgaricus rr grown in skimmed milk. Carbohydrate Research. 239:209-226.

61. Guzel-Seydim, Z.B., Sezgin, E. y Seydim, A.C. (2005). Influences of Exopolysaccharide Producing Cultures on the Quality of Plain Set Type Yogurt. Food Control. 16:205-209. 


\section{CAPÍTULO VI. BIBLIOGRAFÍA}

62. Hardy, L., Jacques, N.A., Forester, H., Campbell, L.K., box K.W. y Wicken, A. J. (1981). Effect of fructose and other carbohydrates on the surface properties, lipoteichoic acid production, and extracellular proteins of Streplococcus mutans grown in continuous culture. Infect Immunology. 31:78.

63. Hart, F.L. (1991). Análisis modernos de los alimentos. Zaragoza, España: Acribia. pp. 166-175.

64. Hassan, A. N., Frank, J. F., Farmer, M. A., Schmidt, K.A. \& Shalabi, S. I. 1995 Observation of encapsulated lactic acid bacteria using confocal scanning laser microscopy. Journal of Dairy Science. 78:2624-2628

65. Hassan, A.N., Corredig, M., Frank, J.F. y Elsoda, M. (2004). Microstructure and Rheology of an Acid-Coagulated Cheese (Karish) made with an ExopolysaccharideProducing Streptococcus thermophilus Strain and its Exopolysaccharide Non-Producing Genetic Variant. Journal of Dairy Research. 71:116-120.

66. Hassan, A.N., Frank, J.F. y Corredig, M. (2002). Microstructure of Feta Cheese Made Using Different Cultures as Determined by Confocal Scanning Laser Microscopy. Journal of Food Science. 67:2750-2753.

67. Hassan, A. y Frank, J.F. (1997). Modification of Microstructure and Texture of Rennet Curd by Using a Capsule-Forming Non-Ropy Lactic Culture. Journal of Dairy Reserch. 64:115-121.

68. Hawthorn, J. (1993). Cap. VI. El queso: Elaboración y tipos. En: Fundamentos de la ciencia de los alimentos. (pp. 147-156). Zaragoza, España: Acribia.

69. Hess, S.J., Roberts, R.F. y Zieglier, G. (1997). Rheological Properties of Non-Fat Yogurt Stabilized Using Lactobacillus delbrueckii subsp. bulgaricus Producing Exopolysaccharide or Using Commercial Stabilizer Systems. Journal of Dairy Science. 80:252-263.

70. Holt, J., Krieg, N.R., Sneath, P.H.A., Staley, J.H. y William, S. (1994). Bergey's Manual of Determinative Bacteriology (9a. ed.) de William and Wilkings. E.U.A. pp. 532.

71. Hosono, A., Lee, J., Ametani, A., Natsume, M., Hirayama, M., Adachi, T. y Kaminogawa, S. (1997). Characterization of a water-soluble polysaccharide fraction with inmunopotentiating activity from Bifidobacterium adolescentis M101-4. Bioscience Biotechnology and Biochemestry. 61:312-316.

72. Hwang, C.H. y Gunasekaran, S. (2001). Measuring crumbliness of some commercial Queso Fresco-type latin American cheeses. Milchwissenschaft. 56: 446-450. 


\section{CAPÍTULO VI. BIBLIOGRAFÍA}

73. Ibáñez, F.C. y Barcina, Y. (2001). Análisis Sensorial de alimentos, métodos y aplicaciones. Barcelona, España: Springer. pp. 78 - 84.

74. ISO 8586-1:1993(E). Sensory analisys - General guidance for the selection, training and monitoring os assessors.

75. ISO 11036:1994(E). Sensory analisys - Methodology - Texture profile.

76. Jack, F.R. y Paterson, A. (1992). Texture of Hard Cheeses. Trends in Food Science and Technology. 3:160-164.

77. Jack, F.R., Paterson, A. y Piggott, J.R. (1993). Relationships between Rheology and Composition of Cheddar Cheeses and Texture as Perceived by Consumers. International Journal of Food Science and Technology. 28:293-302.

78. Jaros, D., Petrag, J., Rohm, H. y Ulberth, F. (2001). Milk fat composition affects mechanical and rheological properties of processed cheese. Applied Rheology. 11(1):1925.

79. Jellinek, G. (1985). Sensory Evaluation of Food. Chichester, England: Ellis Horwood. pp. $155-161$.

80. Jiménez-Guzmán, J., Flores-Nájera, A., Cruz-Guerrero, A.E. y García-Garibay, M. (2009). Use of an Exopolysaccharide-Producing Strain of Streptococcus thermophilus in the Manufacture of Mexican Panela Cheese. LWT-Food Science and Technology. 42:1508-1512.

81. Kaláb, M. (1979). Microestructure of Dairy foods. Cap. 1: Milk products base don proteina, Journal of Dairy Science. 62(8):1352-1364.

82. Kaláb, M. (1993). Practical aspects of electron microscopy in dairy research. Food Structure. 12:95-114.

83. Kang, K. S. y Cottrell, I. W. (1979). Polysaccharides. In H. J. Peppler and D. Perlman (ed.). Microbial technology: microbial processes. (pp. 417-481). (2a ed. vol. 1.) Academic Press, Inc., New York, N.Y

84. Keating, P. F. y Gaona R. H. (1986). Cap. IX: Queso. En Introducción a la lactología. (249-296). México: Limusa. pp. $241-243$.

85. Kimmel, S. A. y Roberts, R. F. (1998). Development of a growth medium suitable for exopolysaccharide production by Lactobacillus delbrueckii ssp. bulgaricus RR. International Journal of Food Microbiology. 40(1-2):87-92. 


\section{CAPÍTULO VI. BIBLIOGRAFÍA}

86. Kirk, R.S., Sawyer, R. y Egan, H. (1996). Cap. 15. Productos lácteos, Composición y análisis de alimentos de Pearson (pp. 661-662). (2 ed.). México, D.F.: Kirk, R.S., Sawyer, R. y Egan, H. Continental.

87. Kitasawa, H., Harata, T., Uemura, J., Saito, T., Kaneko, T. y Itoh, T. (1998). Phosphate Group requirement for mitogenic activation of lymphocytes by an extracellular phosphopolysaccharide from Lactobacillus delbrueckii spp. bulgaricus. International Journal of Food Microbiology. 40:169-175.

88. Korakli, M., Gänzle, M. G. y Vogel, R. F. (2002). Metabolism by bifidobacteria and lactic acid bacteria of polysaccharides from wheat and rye, and exopolysaccharides produced by Lactobacillus sanfranciscensis. Journal of Applied Microbiology. 92:958965 .

89. Kosikowski, F. (1983). Cheese and fermented milk foods. (4a. ed.). Michigan, E.U.A.: Edwas Brothers.

90. Lavanchy, P., Bérodier, F., Zannoni, M., Noel, Y., Adamo, C., Squella, J. y Herrero, L. (1994). Guide d'evaluation sensorielle de la textura des fromages a pate dure ou semidure. Etude interlaboratoires. Lebensmittel Wissenchat und Tecnhology. 26 :59-68.

91. Lemoine, J., Chirat, F., Wieruszeski, J.M., Strecker, G., Favre, N. y Neeser, J.R. (1997). Structural Characterization of the Exocellular Polysaccharides Produced by Streptococcus thermophilus SFi39 and SFi12. Applied and Environmental Microbiology. 63(9)3512-3518.

92. León-Crespo, F. y Galán-Soldevilla, H. (1991). Avances en Análisis Sensorial y Paneles de Cata. Tomado de: Modernas Tecnologías en el Procesado de Alimentos. Ed. Caja Provincial de Ahorros de Córdoba y ACTA-A. España.

93. Lobato-Calleros, C., Robles-Martínez, J.C., Caballero-Perez, J.F., Aguirre-Mandujano, E. y Vernon-Carter, E.J. (2001), Fat Replacers in Low-Fat Mexican Manchego Cheese. Journal of Texture Studies. 32, 1-14.

94. Low, D., Ahlgren, J. A., Horne, D., Mcmahon, D. J., Oberg, C. J. y Broadbent, J. R. (1998). Role of Streptococcus thermophilus MR-1C Capsular Exopolysaccharide in Cheese Moisture Retention. Applied and Environmental Microbiology. 64 (6): $22147-$ 2151.

95. Lowry, O.H., Rosebrough, N.J., Farr, A.L. y Randall, R.J. (1951) Protein measurementwith the Folin phenol reagent. Journal of Biological Chemistry. 193:265275. 


\section{CAPÍTULO VI. BIBLIOGRAFÍA}

96. Macedo, M. G., Lacroix, C., Gardner, N. J. y Champagne, C. P. (2002). Effect of medium supplementation on exopolysaccharide production by Lactobacillus rhamnosus RW-9595M in whey permeate. International Dairy Journal. 12(5):419-426.

97. Madrid, A. (1999). Tecnología quesera. (2a. ed.). Madrid, España: AMV Ediciones y Mundi Prensa. pp. 17-19.

98. Marcos, A. y Esteban, M.A. (1993). Iberian chesses. En: Fox, P.F. Editor. Chesse: Chemistry Physics and Microbiology. Londres: Chapman \& Hall. Pp.173-219.

99. Marshall, A. D. y Daufin, G. (1995). Physio-chemical aspects of membrane fouling by dairy fluids. International Dairy Federation Special Issue. 9504: 8-35.

100. Marshall, V. M., Dunn, H., Elvin, M., McLay, N., Gu, Y. y Laws, A. P. (2001a). Structural characterisation of exopolysaccharide produced by Streptococcus thermophilus EU20. Carbohydrate Research. 331:413-422.

101. Marshall, V. M., Laws, A. P., Gu, Y., Levander, F., Râdström, P., De Vuyst, L., Degeest, B., Vaningelgem, F., Dunn, H. y Elvin, M. (2001b). Exopolysaccharideproducing strains of thermophilic lactic acid bacteria cluster into groups according to their EPS structure. Letters in Applied Microbiology. 32:433-437.

102. Masters, K., 1985, Spray Drying Handbook. 4th ed. Halsted Press, Inc., New York. , Van der Horst, H. C., 1995, Fouling of organic membranes during processing of dairy liquids, 36-52 in IDF Special Issue No. 9504:36-52.

103. McClements, D. J. (2006). Non-covalent interactions between proteins and polysaccharides. Biotechnology Advances. 24:621- 625.

104. McMahon, D. J., Oberg, C. J., y McManus, W. (1993). Functionality of Mozzarella cheese. Austrialan. Journal of Dairy Technology. 48:99-104.

105. Merrill, R. K., Oberg, C. J., y McMahon, D. J. (1994). A method for manufacturing reduced fat Mozzarella cheese. Journalof Dairy Science. 77:1783-1789.

106. Mohsenin, N.N. (1970). Physical Properties of Plant and Animal Materials. (1st Ed.). Gordon and Breach Science Publishers, New York.

107. Monsan, P., Bozonnet, S., Albenne, C., Joucla, G., Willemot, R. M. y Remaud-Simeón, M. (2001). Homopolysaccharides from lactic acid bacteria. International Dairy Journal. 11:675-686. 


\section{CAPÍTULO VI. BIBLIOGRAFÍA}

108. Mozzi, F., Vaningelgem, F,. Hebert, E. M., Van der Meulen, R. M., Moreno, R. F., Font de Valdez, G. y de Vuyst, L. (2006). Diversity of heteropolysaccharideproducing lactic acid bacterium strains and their biopolymers. Applied and Environmental Microbiology 72(6):4431-4435.

109. Murray, R.G.E., Deutsch, R. N. y Robinow, C. F. (1994). Determinative and cytological light microscopy. in Methods for General and Molecular Biology, P. Gerhardt, ed. Am. Soc. Microbiol., Washington, DC. P. 21.

110. NMX-F-184-1985. (1985). Norma Oficial Mexicana. Queso Tipo Gruyere. México

111. NMX-F-209-1985. (1985). Norma Oficial Mexicana. Queso Tipo Chihuahua. México

112. NMX-F-470-1985. (1985). Norma Oficial Mexicana. Queso Tipo Suizo. México

113. NMX-F-471-1985. (1985). Norma Oficial Mexicana. Queso Tipo Chester. México

114. NMX- F-462-1984. (1984). Norma Oficial Mexicana. Queso tipo Manchego. México.

115. NMX-F-733-COFOCALEC-2010. (2010). Norma Mexicana COFOCALEC (Consejo para el fomento de la calidad de la leche y sus serivados, A.C.). Sistema Producto Leche-Alimentos-Lácteos-Queso Oaxaca-denominaciones, especificaciones y métodos de prueba. México.

116. NMX-F-735-COFOCALEC-2011. (2011). Norma Mexicana COFOCALEC (Consejo para el fomento de la calidad de la leche y sus serivados, A.C.). Sistema Producto Leche-Alimentos-Lácteos-Alimento lácteo regional- Queso Cotija artesanal madurado Denominación, especificaciones y métodos de prueba. México.

117. NOM-243-SSA1-2010. Norma Oficial Mexicana. (2010). Productos y servicios. Leche, fórmula láctea, producto lácteo combinado y derivados lácteos. Disposiciones y especificaciones sanitarias. Métodos de prueba. México.

118. O'Connor y O'Brien. (2000). Nutritional aspects of chesse. En. Fundamentals of chesse science. Eds. Fox, P.F., Guinee, T.P., Cogan, T.M. and McSweeney, P.L.H. Maryland: Aspen Publishers. 504-513.

119. Oberg, C. J. y Broadbent J. R. (1993). Thermophilic starter cultures: another set of problems. Journal of Dairy Science. 76:2392-2406.

120. Olivares, S.N. (1988). Estudio de la agroindustria quesera en la Costa de Chiapas, Tesis de licenciatura. UACh-DIA. Chapingo, México.

121. Osman, S., Fen. W. F. y Fisham, M. L. (1986). Exopolysaccharides of the phytopathogen Pseudomonas syringae. Journal of Bacteriology. 166:66. 


\section{CAPÍTULO VI. BIBLIOGRAFÍA}

122. Palm, R. (1998). L'analyse en composantes principales: principe et aplicaction. Notes de statistique et d'informatique. Gembloux, Belgique.

123. Pedrero, D.L. y Pangbom, R.M. (1989). Evaluación Sensorial de los Alimentos. Métodos Analíticos. México: Alhambra (Addison Wesley Lonman). pp. 92 - 96.

124. Perry, D.B., Mcmahon, D.J. y Oberg, C.J. (1997). Effect of ExopolysaccharideProducing Cultures On Moisture Retention In Low Fat Mozzarella Cheese. Journal of Dairy Science. 80:799-805.

125. Petersen, B.L., Dave, R.I., McMahon, D.J., Oberg, C.J. y Broadbent, J.R. (2000). Influence of Capsular and Ropy Exopolysaccharide-Producing Streptococcus thermophilus on Mozzarella Cheese and Cheese, Whey. Journal of Dairy Science. 83:1952-1956.

126. Petry, S., Furlan, S., Crepeau, M.J., Cerning, J. y Desmazeaud, M. (2000). Factors affecting exopolysaccharide production by Lactobacillus delbrueckii subsp. Bulgaricus grown in a chemically definied medium. Applied and Environmental Microbiology. 66:3427-3431.

127. Petry, S., Furlan, S., Waghorne, E., Saulnier, L., Cerning, J. y Maguin, E. (2003). Comparison of the thickening properties of four Lactobacillus delbrueckii subsp. bulgaricus strains and physicochemical characterization of their exopolysaccharides. FEMS Microbiology Letters. 221(2):285-291.

128. Pham, P.L., Dupont, I., Roy, D. Lepointe, G. y Cerning, J. (2000). Prodution of exopolysaccharide by Lactobacillus rhamnosus $\mathrm{R}$ and analisys of its enzymatic degradation during prolong fermentation. Applied and Environmental Microbiology. 66:2302-2310.

129. Pigeon, R. M., Cuesta, E. P. y Gilliland S. E. (2002). Binding of free bile acids by cells of yogurt starter culture bacteria. Journal of Dairy Science. 85:2705-2710.

130. Pilosoft, A.M.R. (2010). Impacto de la interacción entre la $\beta$-lactoglobulina, caseinoglicomacropéptido y polisacáridos en coloides alimentarios. Tesis. Universidad de Buenos Aires, Argentina. pp. 27-28.

131. Rawson, L. y Marshal, M. (1997). Effect of ropy strains of Lactobacillus delbrueckii spp. Bulgaricus and Streptococcus thermophilus on rheology of stirred yogurt. Interntional Journal of Food Science Technology. 32, 213-220.

132. Revista del consumidor. Instituto Nacional del Consumidor. Estudio de calidad: Quesos Oaxaca. (2012, Junio). 424. 38-47 


\section{CAPÍTULO VI. BIBLIOGRAFÍA}

133. Revista del consumidor. Instituto Nacional del Consumidor. Quién es quién en la calidad de los quesos. (1990, Mayo). 159. pp. II-XVI.

134. Richard, J., Auclair, J., Schneid, N., Hermier, J., Cerf, O., Maubois, L. y Desmazeud, M. (1990). Parte 2, Capítulo 2: La leche de quesería, en El Queso, editor Eck, André, Barcelona, España, p.p. 134 y 135, 159 - 160.

135. Roberts, C. M., Fett, W. F. Osman, S. F. Wijey, C. O’Oonnor, J. V. y Hoover, D. G. (1995). Exopolysaccharide production by Bifidobacterium longum BB-79. Journal of Applied Bacteriolology. 78:463-468

136. Ruas-Madiedo, P. y De los Reyes-Gavilán, C.G. (2005). Invited Review: Methods for the Screening, Isolation, and Characterization of Exopolysaccharides Produced by Lactic Acid Bacteria. Journal of Dairy Science. 88:843-856.

137. Ruas-Madiedo, P., Tuinier, R., Kanning, M. y Zoon, P. (2002). Role of exopolysaccharides produced by Lactococcus lactis subsp. Cremoris on the viscosity of fermented milks. International Dairy Journal. 12:689-695.

138. Rynne, N.M., Beresford, T.P., Kelly, A.L., Tunick, M.H., Malin, E.L. y Guinee, T.P. (2007), Effect of Exopolysaccharide-Producing Adjunct Starter Cultures on the Manufacture, Composition and Yield of Half-Fat Cheddar Cheese, Australian Journal of Dairy Technology, 62:12-18.

139. Sancho, J., Bota, E. y De Castro, J.J. (2002). Análisis Sensorial de los alimentos. Barcelona, España: Alfaomega. pp. 96 - 97, 207 - 218.

140. Santos, M.A. (1991). Cap. 2: Características de la leche y Cap. 5: Elaboración de quesos. En: Leche y sus derivados. (pp. 27-33, 117-206). México, D.F.: Trillas.

141. Schellhaassand, S.M. y Morris, H.A. (1985). Rheological and scanning electron microscopic examination of skim milk gels obtained by fermenting with ropy and nonropy strains of lactic acid bacteria. Food Microstructure. 4:279.

142. Sherman, P. (1975). Factors influencing the instrumental and sensory evaluation of food emulsions, in theory, determination and control of physical properties of food materials, C.-K. Rha. (pp. 251-266). Dordrecht-Holland: D. Reidel.

143. Sikkema, J. y Oba, T. (1998). Extracellular polysaccharides of lactic acid bacteria. Snow Brand R\&D Reports. 107:1-31.

144. Sutherland I. W. (1972). Bacterial exopolysaccharides. Advances in Microbial Physiology. 8:143-212. 


\section{CAPÍTULO VI. BIBLIOGRAFÍA}

145. Szczesniak, A.S. (1963). Consumer awareness of texture and other food attributes. Food Technology. 17 (1):74

146. Teggatz, J.A. y Morris, H.A. (1990), Changes in the reology and microstructure of ropy yogurt during shearing, Food Structure. 9:133-138.

147. Tuinier, R., van Casteren, W.H.M., Looijesteijn, P.J. Schols, H.A., Voragen, A.G.J. y Zoon, P. (2001). Effects of structural modifications on some physical characteristics of exo-polysaccharides from Lactococcus lactis. Biopolymers. 59:160-166.

148. Tunick M.H., Mackey, K.L., Shieh, J.J., Smith, P.W., Cooke, P. y Malin, E.L. (1993a). Rheology and Microstructure of Low-Fat Mozzarella Cheese. International Dairy Journal. 3: 649-662.

149. Tunick, M.H., Malin, E.L., Smith, P.W., Shieh J.J., Sullivan B.C., Mackey, K.L. y Holsinger, V.H. (1993b). Proteolysis and Rheology of Low-Fat and Full-Fat Mozzarella Cheeses Prepared from Homogenized Milk. Journal of Dairy Science. 76:3621-3628.

150. Tunick, M.H., Mackey, K.L., Smith, P.W. y Holsinger, V.H. (1991). Effects of Composition and Storage on the Texture of Mozzarella Cheese. Netherlands Journal of Milk and Food. 45: 117-125.

151. Tunick, M.H., Van Hekken, D.L., Call, J., Molina-Corral, F.J. y Gardea, A.A. (2007). Queso Chihuahua: Effects of Seasonality of Cheesemilk on Rheology. International Journal of Dairy Technology. 60:13-21.

152. Van den Berg, D.J.C., Robijn, G.W., Janssen, A.C., Giuseppin, M.L.F., Vreeker, R., Kamerling, J.P., Vliegenthart, J.F.G., Ledeboer, A.M. y Verrips, C.T. (1995). Production of a novel extracellular polysaccharide by Lactobacillus sake 0-1 and characterization of the polysaccharide. Applied and Environmental Microbiology. 61:2840-2844.

153. Van Geel-Schutten, G. H., Faber, E. J., Smit, E., Bonting, K., Smith, M. R., ten Brink, B., Kamerling, J. P., Vliegenthart, J. F. G. y Dijkhuizen, L. (1999). Biochemical and structural characterization of the glucan and fructan exopolysaccharides synthesized by Lactobacillus reuteri wild-type strain and by mutant strains. Applied and Environmental Microbiology. 65:3008-3014.

154. Van Hekken, D.L., Tunick, M.H., Tomasula, P.M., Molina-Corral, F.J. y Gardea, A.A. (2007). Mexican Queso Chihuahua: Rheology of Fresh Cheese. International Journal of Dairy Technology. 60:5-12.

155. Vaningelgem, F., Zamfir, M., Mozzi, F., Adriany, T., Vancanneyt, M., Swings, J. y De Vuyst, L. (2004). Biodiversity of exopolysaccharides produced by Streptococcus thermophilus strains is reflected in their production and their molecular and functional characteristics. Applied and Environmental Microbiology. 70(2):900-912. 
156. Varnam, A. H. y Sutherland, J. P. (1994). Leche y productos lácteos, terminología, química y microbiología, Serie alimentos básicos 1. Zaragoza, España: Acribia. pp. 292 $-295,339-340$.

157. Villegas, A. (2003), Los quesos mexicanos, México, D.F.: CIESTAAM. pp. 15-18, 23, 26-27, 113-116.

158. Vizuata, B. (1998). Análisis estadístico con SPSS para Windows. Estadística multivariable. McGraw-Hill. Madrid, españa

159. Voisey, P.W. (1975). Selecting deformation rates in texture test. Journal of Texture Studies. 9:311-324.

160. Wacher-Rodarte, C., Galván, M.V., Farrés, A., Gallardo, F., Marshall, V.M.E. y GarciaGaribay, M. (1993). Yogurt Production from Reconstituted Skim Milk Powders Using Different Polymer and Non-Polymer Forming Starter Cultures. Journal of Dairy Research. 60: 247-254.

161. Whicken, A.J., Ayes, A., Campbell, L.K. y Knox, K.W. (1983). Effect of growth condition on production of rahmnose-containing cell wall and capsular polysaccharides by strain of Lactobacillus casei subsp. rhamnosus. Journal of Bacteriology. 153:84-92.

162. Yong, K.J. y Young, W.P. (1996). SDS-PAGE of Proteins in Goat Milk Cheeses Ripened under Different Conditions. Journal of Food Science. 61:490-495.

163. Zisu, B. y Shah, N.P. (2005). Textural and funcional changes in low-fat Mozzarella cheese in relation to proteolysis and microstructure as influenced by the use of fat replacers, pre-acidification and EPS starter. International Dairy Journal. 15(6-9):957972.

164. Zisu, B. y Shah, N.P. (2007). Texture characteristics adn pizza bake properties of low-fat Mozzarella cheese as influenced by pre-acidication with citric acid and use of encapsulated and ropy exopolysaccharide producing cultures. International Dairy Journal. 17(8):985-997. 
CAPÍTULO VII. ANEXOS

\section{CAPÍTULO VII. ANEXOS}




\section{CUESTIONARIO 1. ENCUESTA DE SALUD Y HÁBITOS ALIMENTICIOS}

\section{AQI UNIVERSIDAD AUTÓNOMA METROPOLITANA}

La información que se le solicita es confidencial. Por favor, si está de acuerdo, rellene el presente cuestionario.

Apellidos: Nombre:

Sexo: $\mathrm{H}$ $\square \mathrm{M}$

Teléfono: Casa Celular: Oficina:

E-mail:

\begin{tabular}{|c|c|c|c|c|}
\hline Estudios: & $\square$ Secundaria & $\square$ Preparatoria & $\square$ Licenciatura & $\square$ Posgrado \\
\hline Edad: & $\square$ Menos de 35 & $\square$ Entre 35 y 50 años & $\square$ Más de 50 años & \\
\hline Estado Civil: & $\square$ Soltero & $\square$ Casado & & \\
\hline Hijos: & $\square 0$ & $\square 2$ & $\square 3$ & 4 ó más \\
\hline
\end{tabular}

1.- Señale si ha tenido o tiene problemas (alergia, intolerancia o aversión) con los siguientes alimentos, especificando la respuesta si fuera posible:

Leche:

Queso:

Verduras:

Cereales:

Frutas:

Carnes:

Pescados:

Bebidas alcohólicas:

Café:
Huevos:

Otros lácteos:

Legumbres secas:

Harinas:

Especias:

Embutidos:

Mariscos:

Otras bebidas:

Chocolates:

2.- Si Ud. Sigue una dieta especial, señale de qué tipo:

\begin{tabular}{ll}
$\square$ Diabética & $\square \begin{array}{l}\text { Hiposódica (bajo contenido de sal) } \\
\text { Hipercalórica (alta en calorías) }\end{array}$ \\
\hline $\begin{array}{l}\text { Vegetariana } \\
\text { Hipocalórica (baja en calorías) }\end{array}$
\end{tabular}

3.- Señale en la casilla correspondiente su actitud hacia los alimentos que figuran en la lista siguiente. Tome como referencia la siguiente escala:
a. Nunca lo probaría
1. Me desagrada muchísimo
b. Nunca lo he probado
2. Me desagrada mucho
3. Me desagrada algo
4. Ni me agrada ni me desagrada
5. Me agrada algo
6. Me agrada mucho
7. Me agrada muchísimo 
CAPÍTULO VII. ANEXOS

\begin{tabular}{|l|l|l|l|l|l|l|l|l|l|}
\hline & a & b & $\mathbf{1}$ & $\mathbf{2}$ & $\mathbf{3}$ & $\mathbf{4}$ & $\mathbf{5}$ & $\mathbf{6}$ & $\mathbf{7}$ \\
\hline LECHE Y DERIVADOS & & & & & & & & & \\
\hline
\end{tabular}

4. Indique la frecuencia diaria con la que fuma:

$\square$ Nunca $\square$ Menos de 5 cigarrillos $\square$ De 5 a 10 cigarrillos
$\square$ De 15 a 25 cigarrillos $\square$ De 10 a 15 cigarrillos
más de 25 cigarrillos

5. Señale su disponibilidad y su preferencia, tanto semanal como diaria, para participar en ensayos de prueba.
$\square$ Lunes
$\square$ Martes
Miércoles
Jueves
Viernes

Horario de la mañana (de 11 a 14 horas)

Horario de la tarde (de 16:00 a 18:00 horas)

Gracias por su colaboración 


\section{AQIUNIVERSIDAD AUTÓNOMA METROPOLITANA}

Prueba las muestras en el orden que se te presentan y marca con una cruz el sabor percibido. No te tragues la muestra. Entre cada degustación enjuágate la boca con el agua que tienes en el vaso marcado. Degusta toda la muestra para no volver a probar. Gracias

NOMBRE DEL JUEZ:

FECHA:

\begin{tabular}{|l|l|l|l|l|l|}
\hline CLAVE & $\begin{array}{l}\text { Sabor no } \\
\text { identificado }\end{array}$ & Ácido & Amargo & Salado & Dulce \\
\hline 901 & & & & & \\
\hline 837 & & & & & \\
\hline 049 & & & & & \\
\hline 516 & & & & & \\
\hline 623 & & & & & \\
\hline 650 & & & & & \\
\hline 287 & & & & & \\
\hline
\end{tabular}

No escribir en esta zona.

RESULTADOS OBTENIDOS

\begin{tabular}{|c|c|c|}
\hline SABOR & $\begin{array}{c}\text { No. DE MUESTRAS } \\
\text { PRESENTADAS EN LA SERIE }\end{array}$ & $\begin{array}{c}\text { IDENTIFICACIÓN CORRECTA } \\
(\%)\end{array}$ \\
\hline Ácido & & \\
\hline Amargo & & \\
\hline Salado & & \\
\hline Dulce & & \\
\hline
\end{tabular}




\section{CUESTIONARIO 3. DIFERENCIACIÓN ENTRE NIVELES DE INTENSIDAD DE ESTÍMULOS}

\section{AQIUNIVERSIDAD AUTÓNOMA METROPOLITANA}

Nombre:

Fecha:

1.- INSTRUCCIONES: Pruebe las muestras de izquierda a derecha y ordénelas según su incremento de intensidad de dulzura, considerando que 1 = mínima y $4=$ máxima dulzura.

$\begin{array}{lllll}\text { Muestras: } & 875 & 228 & 957 & 508\end{array}$

Orden

2.- INSTRUCCIONES: Pruebe las muestras de izquierda a derecha y ordénelas según su incremento de intensidad de salado, considerando que 1 = mínimo y 4 = máximo salado.

$\begin{array}{lllll}\text { Muestras: } & 508 & 258 & 869 & 043\end{array}$

Orden

3.- INSTRUCCIONES: Pruebe las muestras de izquierda a derecha y ordénelas según su incremento de intensidad de acidez, considerando que 1 = mínima y 4 = máxima acidez.

$\begin{array}{lllll}\text { Muestras: } & 648 & 571 & 815 & 490\end{array}$

Orden

4.- INSTRUCCIONES: Pruebe las muestras de izquierda a derecha y ordénelas según su incremento de intensidad de amargor, considerando que $1=$ mínimo y 4 = máximo amargor.

$\begin{array}{lllll}\text { Muestras: } & 478 & 501 & 074 & 758\end{array}$

Orden 


\section{CUESTIONARIO 4. PRUEBAS DE DIFERENCIACIÓN DÚO-TRÍO}

\section{AQI UNIVERSIDAD AUTÓNOMA METROPOLITANA \\ Casa abierta al tiempo}

Nombre:

Fecha:

Serie:

Instrucciones: Primero pruebe la referencia $\mathrm{R}$ y luego las demás muestras, de izquierda a derecha del primer par, encierre en un círculo aquella muestra del par que sea igual a la referencia. Enjuague su boca y continúe con el siguiente par, después de haber probado R. No se trague las muestras. Gracias.

\section{$\mathbf{R}=$ Referencia}

\begin{tabular}{|l|cc|}
\hline Par & Muestras \\
\hline $\mathbf{1}$ & 392 & 815 \\
\hline $\mathbf{2}$ & 781 & 600 \\
\hline $\mathbf{3}$ & 226 & 112 \\
\hline
\end{tabular}


PARES.

\section{AQI UNIVERSIDAD AUTÓNOMA METROPOLITANA}

Nombre:

Fecha:

Instrucciones:

Para cada serie, pruebe las muestras de izquierda a derecha. Encierre en un círculo el número de muestra que sea más Enjuáguese la boca antes de continuar con el siguiente grupo. Continúe con la siguiente serie realizando el mismo procedimiento.

$\begin{array}{ll}875 & 228 \\ 508 & 210 \\ 957 & 571 \\ 726 & 648 \\ 815 & 490 \\ 917 & 478 \\ 501 & 758 \\ 074 & 516 \\ 049 & 837 \\ 258 & 650 \\ 623 & 287\end{array}$

\section{Instrucciones:}

Para cada serie, pruebe las muestras de izquierda a derecha. Encierre en un círculo el número de muestra que sea más Enjuáguese la boca antes de continuar con el siguiente grupo. Continúe con la siguiente serie realizando el mismo procedimiento.

$\begin{array}{ll}875 & 228 \\ 508 & 210 \\ 957 & 571 \\ 726 & 648 \\ 815 & 490 \\ 917 & 478 \\ 501 & 758 \\ 074 & 516 \\ 049 & 837 \\ 258 & 650 \\ 623 & 287\end{array}$




\section{AQMUNIVERSIDAD AUTÓNOMA METROPOLITANA}

Nombre:

Fecha:

\section{INSTRUCCIONES:}

Pruebe las siguientes series de muestras de izquierda a derecha y ordénelas según su incremento de intensidad del atributo correspondiente, considerando que $1=$ mínimo y $5=$ máximo:

1.- DUREZA

Muestras: $\quad 646$

235

470

338

876

Orden

2.- COHESIVIDAD

Muestras: $\quad 123$

960

854

512

251

Orden

3.- ELASTICIDAD

Muestras: $\quad 498$

319

781

630

956

Orden

4.- MASTICABILIDAD

Muestras: $\quad 649$

412

951

854

365

Orden 
CUESTIONARIO 7. PRUEBA DESCRIPTIVA CUANTITATIVA

\section{ATI UNIVERSIDAD AUTÓNOMA METROPOLITANA}

Nombre:

Fecha:

INSTRUCCIONES: Favor de marcar con una línea vertical sobre la línea horizontal, el punto que mejor describa el atributo de la muestra.

MUESTRA 1. Poco Mucho

1.- COHESIVIDAD

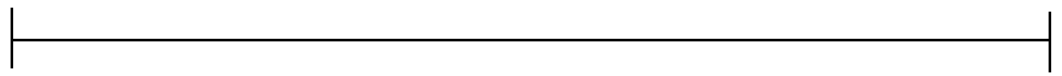

2.- MASTICABILIDAD

3.- DUREZA

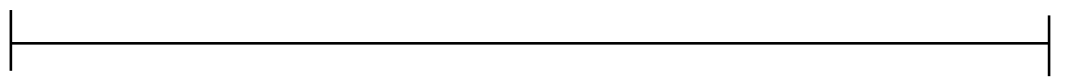

4.- ELASTICIDAD

MUESTRA 2. Poco

Mucho

1.- COHESIVIDAD

2.- MASTICABILIDAD

4.- DUREZA

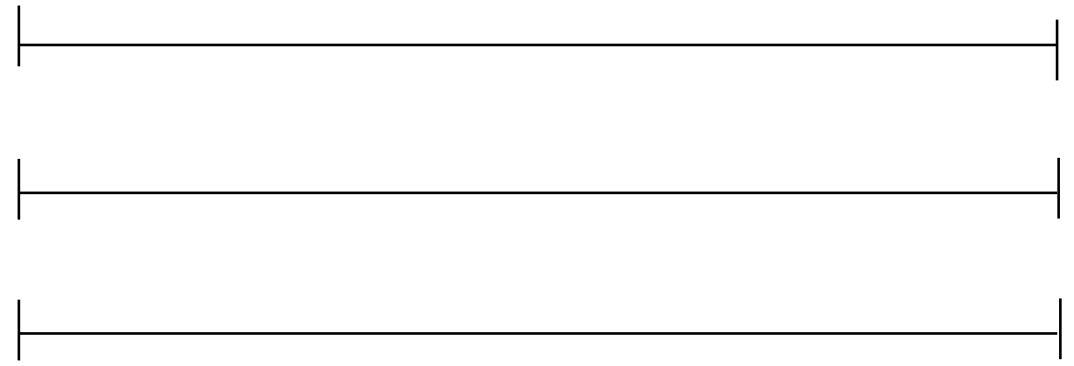

5.- ELASTICIDAD 
CUESTIONARIO 8. PRUEBA DESCRIPTIVA CUANTITATIVA

\section{AQI UNIVERSIDAD AUTÓNOMA METROPOLITANA}

Nombre:

Fecha:

INSTRUCCIONES: Favor de marcar con una línea vertical sobre la línea horizontal, el punto que mejor describa el atributo de la muestra.

MUESTRA 1. Poco Mucho

1.- COHESIVIDAD

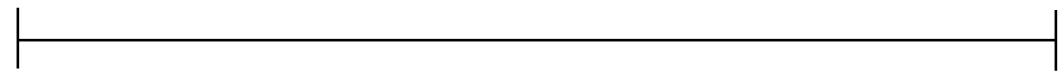

2.- MASTICABILIDAD

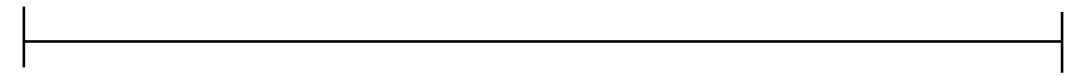

3.- DUREZA

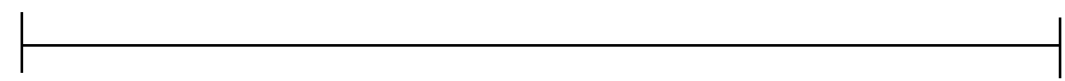

4.- ELASTICIDAD

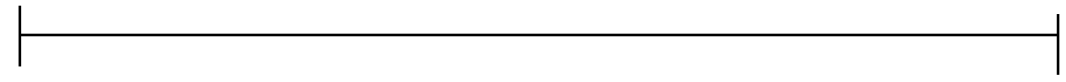

MUESTRA 2.

Poco

Mucho

1.- COHESIVIDAD

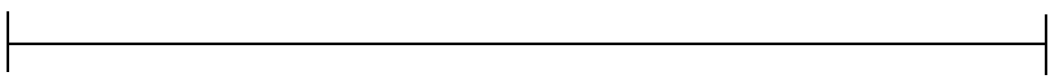

2.- MASTICABILIDAD

4.- DUREZA

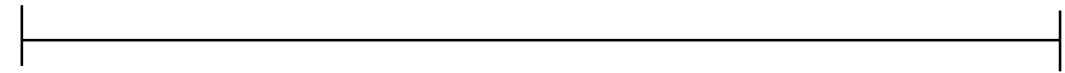

5.- ELASTICIDAD

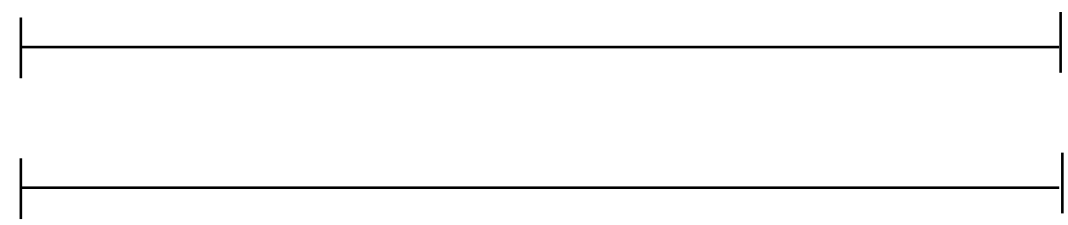




\section{Effect of an exopolysaccharide-producing strain of Streptococcus thermophilus on the yield and texture of Mexican manchego-type cheese}

\begin{tabular}{|r|l|}
\hline Journal: & International Journal of Food Properties \\
\hline Manuscript ID: & LJFP-2011-0102.R2 \\
\hline Manuscript Type: & Original Article \\
\hline Date Submitted by the Author: & O1-Jun-2011 \\
\hline Complete List of Authors: & $\begin{array}{l}\text { Lluis-Arroyo, Diana; Universidad Autonoma Metropolitana, Biotechnology } \\
\text { Flores-Najera, Angelica; Universidad Autonoma Metropolitana, } \\
\text { Biotechnology } \\
\text { Cruz-Guerrero, Alma; Universidad Autonoma Metropolitana, Biotechnology } \\
\text { Gallardo-Escamilla, Francisco; Universidad Autonoma Metropolitana, } \\
\text { Biotechnology } \\
\text { Lobato-Calleros, Consuelo; Universidad Autonoma de Chapingo, } \\
\text { Departamento de Preparatoria Agricola } \\
\text { Jimenez-Guzman, Judith; Universidad Autonoma Metropolitana, } \\
\text { Biotechnology } \\
\text { Garcia-Garibay, Mariano; Universidad Autonoma Metropolitana, } \\
\text { Biotechnology }\end{array}$ \\
\hline Keywords: & $\begin{array}{l}\text { cheese, Streptococcus thermophilus, Exopolysacharide, texture profile } \\
\text { analysis, Ropy culture }\end{array}$ \\
\hline
\end{tabular}

\section{SCHOLARONE" \\ Manuscripts}


1

2

3

4

5

6

7

8

9

10

11

12

13
Mexican manchego-type cheese

Diana Lluis-Arroyo ${ }^{1}$, Angélica Flores-Nájera ${ }^{1}$, Alma Cruz-Guerrero ${ }^{1}$, Francisco

$$
\text { Gallardo-Escamilla }^{1 \dagger} \text {, Consuelo Lobato-Calleros }{ }^{2} \text {, Judith Jiménez-Guzmán }{ }^{1} \text {, }
$$

Mariano García-Garibay ${ }^{1}$

8

\footnotetext{
${ }^{1}$ Departamento de Biotecnología, Universidad Autónoma Metropolitana,
} Iztapalapa Av. San Rafael Atlixco 186, Col. Vicentina, México D.F. 09340,

\section{México}

${ }^{2}$ Departamento de Preparatoria Agrícola, Universidad Autónoma Chapingo, 56230 Texcoco, Mexico

\section{Corresponding author: Dr. Mariano García-Garibay, Departamento de}

Biotecnología, Universidad Autónoma Metropolitana, Iztapalapa Av. San Rafael Atlixco 186, Col. Vicentina, México D.F. 09340, México Tel.: +(52)(55)5804-4720; fax: +(52)(55)5804-4712. E-mail: jmgg@xanum.uam.mx Running title: Yield and texture of ropy manchego-type cheese

\footnotetext{
${ }^{\dagger}$ Deceased
} 


\section{ABSTRACT}

28 An exopolysaccharide (EPS)-producing strain of Streptococcus thermophilus was

29 evaluated in the production of Mexican manchego-type cheese. This ropy strain

30 improved water and fat retention, significantly increased cheese yield.

31 Furthermore, the ropy strain cheese retained more moisture than control cheese

32 during ripening, suggesting that EPS strongly bound water within the protein

33 matrix of the cheese. Scanning electron microscopy (SEM) confirmed that EPS

34 bound to the protein matrix of the cheese, producing a dense network that helped

35 to increase water and fat retention and leading to a more open structure of the

36 cheese that gave a softer product, as confirmed by instrumental texture profile

37 analysis (TPA) and sensory evaluation. Comparison of SEM micrographs of the

38 different sections of the cheese showed higher concentration of EPS in the centre

39 than in the outer sections, indicating that EPS production continued during

40 ripening and that the environment at the centre of the cheese (moisture and/or

41 oxygen concentration) favoured EPS production. Instrumental TPA also

42 demonstrated that the ropy strain cheese was more cohesive and less elastic than

43 control; in contrast, EPS did not affect chewiness. The changes in texture could be

44 correlated to composition: hardness increased as water and fat decreased, while

45 springiness decreased with increasing fat. The interactions of EPS with the cheese

46 protein matrix had an affect on the increase in cohesiveness of the ropy strain

47 cheese.

48

49 Keywords: Streptococcus thermophilus, exopolysaccharide-producing lactic acid

50 bacteria, Mexican manchego-type cheese, texture profile analysis, ropy culture. 


\section{INTRODUCTION}

53

54 Exopolysaccharide (EPS)-producing lactic acid bacteria (LAB) have been used in 55 the production of some dairy products. Most studies that have used this kind of 56 bacteria have been performed in yoghurt, where it has been shown to increase 57 viscosity or decrease product syneresis (1). These characteristics could be useful 58 in generating other dairy products such as cheese. Among the studies involving 59 cheese, it has been reported that the use of a capsule-forming strain produced

60 microstructural changes in the curd of mozzarella cheese, eliciting a more open 61 casein network with larger pore sizes and softer texture than control cheese (2). 62 Other investigations have reported that the use of a capsule-forming strain of 63 Streptococcus thermophilus in mozzarella cheese production increases its 64 moisture content, hence improving its melting properties $(3,4,5)$. Besides 65 mozzarella, other types of cheese using EPS-producing cultures include feta (6), 66 in which non-fat cheese made with a non-capsule-forming culture have a more 67 compact structure compared to that made with a capsule-forming culture, karish, 68 an Egyptian acid-coagulated cheese (7), half-fat cheddar (8) and panela, a fresh 69 Mexican cheese (9). In all cases, textural modifications were observed. However, 70 to the best of our knowledge, very little work has been undertaken with full fat 71 cheese, where the fat content determines characteristics such as flavour and 72 texture. The influence of EPS on fat retention, yield improvement and textural 73 properties has not been widely assessed. 
75 Most types of Mexican cheese are fresh, similar to most fresh white Latin

76 American cheeses. However, about $20 \%$ of the Mexican cheese market is

77 composed of ripened cheese, the main representatives being the manchego-type

78 and Chihuahua. These are very similar: slightly ripened with a semi-hard texture

79 and usually made with a combination of mesophilic and thermophilic cultures.

80 The yield achieved for slightly ripened cheese is lower than that of fresh types of

81 cheese, which makes them less competitive in the Mexican market. Thus,

82 anything that could help increase yield without diminishing its taste and quality

83 would increase the competitiveness of these products. The aim of the current

84 study was to evaluate the use of Streptococcus thermophilus SY-102, an EPS-

85 producing strain, on the yield and fat retention and some physical attributes of

86 Mexican manchego-type cheese.

87

88 MATERIALS AND METHODS

89

$90 \quad$ Milk

91 Fluid pasteurised and homogenised whole cow milk containing $30 \mathrm{~g} \cdot \mathrm{L}^{-1}$ fat, 31

$92 \mathrm{~g} \cdot \mathrm{L}^{-1}$ protein and a density of $1.032 \mathrm{~g} \cdot \mathrm{mL}^{-1}$ (Santa Clara, Productos Lácteos S.A.

93 de C.V., Mexico City) was used to produce cheese.

94

95 Starter cultures

96

97 The ropy strain cheese was developed with a commercial mixed culture of

98 Lactococcus lactis subsp. lactis and Lactococcus lactis subsp. cremoris (Rhône-

Comment [T1]: This has not been mentioned in the Introduction. Would it be good to include a sentence in the Introduction describing this? 
99 Poulenc de Mexico, Mexico City) plus the ropy strain Streptococcus thermophilus

100 SY-102 (Rhodia-Texel Ltd., London, UK). The milk for cheese production was

101 inoculated with $2 \%$ of the mesophilic cultures plus $0.5 \%$ of the S. thermophilus

102 culture. The control cheese was produced with $2 \%$ of the mesophilic cultures, but

103 the EPS-producing S. thermophilus strain was replaced with the non-ropy strain

104 Streptococcus thermophilus TA050 (Rhône-Poulenc of Mexico, Mexico City).

105 Starter cultures were prepared by incubating at either $37^{\circ} \mathrm{C}$ (mesophilic) or $42^{\circ} \mathrm{C}$

106 (S. thermophilus) for $18 \mathrm{~h}$ in skimmed milk with $10 \%$ total solids (Svelty, Nestlé,

107 Mexico City), sterilised at $121^{\circ} \mathrm{C}$ for $5 \mathrm{~min}$.

108

109 Cheese making

110

111 The cheese was prepared in triplicate batches in bench cheese vats with $3.5 \mathrm{~L}$ of

112 milk and $0.2 \mathrm{~mL} \cdot \mathrm{L}^{-1}$ of $0.3 \%$ calcium chloride solution (w/w). The milk was

113 incubated at $37^{\circ} \mathrm{C}$ using $2 \%$ of the corresponding starter mixture culture with

114 constant measurements (every $30 \mathrm{~min}$ ) of viscosity, acidity and $\mathrm{pH}$ until $\mathrm{pH}$

115 reached a value of 6.0. The milk was then clotted using microbial rennet $(3.5 \mathrm{~mL}$,

116 strength 1:10000; Cuamex, Mexico City) and incubated for approximately 30 min.

117 After coagulation, the curd was cut into cubes of approximately $1 \mathrm{~cm}$ per side; the

118 temperature was slowly increased $\left(1{ }^{\circ} \mathrm{C} \min ^{-1}\right)$ up to $45^{\circ} \mathrm{C} \pm 2{ }^{\circ} \mathrm{C}$ while the curd

119 was gently stirred. Once the temperature was reached, most of the whey

120 (approximately 80\% of volume) was drained and the curd was kept in the vat

121 flooded as small blocks in the remaining whey, turning the pieces periodically

122 until the lactic acid in the whey reached 0.20 to $0.22 \%$. The cheese was moulded

123 into $1 \mathrm{~kg}$ round moulds and pressed for $24 \mathrm{~h}$ at a constant pressure of $1 \mathrm{~kg} \cdot \mathrm{cm}^{-2}$. 
124 After pressing, the cheeses were submerged in $10 \% \mathrm{NaCl}$ brine and allowed to

125 salt for $24 \mathrm{~h}$ at $10^{\circ} \mathrm{C}$. The cheese was ripened in a chamber $\left(10\right.$ to $12^{\circ} \mathrm{C}, 80$ to $90 \%$

126 relative humidity) for two weeks, turning the cheeses every third day and cleaning

127 the surface with a $0.2 \%$ solution of potassium sorbate.

128

129 Physico-chemical analyses

130

131 Milk apparent viscosity was analysed by means of a Brookfield LV-DV III

132 viscometer (Brookfield Engineering Laboratories Inc., Stoughton, MA, USA).

133 Readings were taken with LV4 or ULA spindles at speeds of 40 and $60 \mathrm{rpm}$,

134 respectively, every $30 \mathrm{~min}$ up to $180 \mathrm{~min}$. Milk and whey acidity were determined

135 by titration with $0.1 \mathrm{~mol} \cdot \mathrm{L}^{-1} \mathrm{NaOH}$ (Sigma Chemicals, Mexico City), using

136 phenolphthalein as indicator. The $\mathrm{pH}$ was determined with a $\mathrm{pH}$-meter

137 Conductronic pH 20 (Conductronic, Mexico City). The moisture content of cheese

138 was analysed using $1 \mathrm{~g}$ of sample dried at $100^{\circ} \mathrm{C}$ to constant weight; total solids

139 were calculated by difference of total weight and moisture. Fat content was

140 determined using the Gerber method. Thereafter, fat in dry weight bases and total

141 solids were calculated (9). Total protein in the cheese was determined by

142 extraction with an $8 \mathrm{~mol} \cdot \mathrm{L}^{-1}$ urea solution at $\mathrm{pH} 8.0$ as reported by Yong \& Young

143 (10). Cheese yield, reported as percentage, was calculated by the ratio between

144 the final weight of cheese at different stages of production and the weight of the

145 milk used for its production.

146

147 Scanning electron microscopy

148 
149 The samples were taken with a cheese probe after 15 days of ripening from three

150 different sections of the cheese (centre, middle and rind). They were cut into

151 pieces of approximately $3 \times 3 \times 1 \mathrm{~mm}$, fixed overnight at $4{ }^{\circ} \mathrm{C}$ in a $10 \mathrm{~mL} \cdot \mathrm{L}^{-1}$

152 glutaraldehyde solution (Electron Microscopy Science, Washington, DC, USA)

153 with $5 \mathrm{mg} \cdot \mathrm{L}^{-1}$ of ruthenium red to stain the EPS, followed by post fixation in

$15420 \mathrm{~g} \cdot \mathrm{L}^{-1}$ osmium tetroxide (Electron Microscopy Science). Dehydration was

155 carried out at room temperature by an ethanol (J.T. Baker) dehydration series (10

156 min each in $25 \%, 50 \%, 75 \%$ and $99 \%$ ethanol solution, and finally three $10 \mathrm{~min}$

157 changes in $100 \%$ ethanol). Final dehydration was performed in a Samadri $780-\mathrm{B}$

158 critical point dryer (Tousimis Research Corporation, Santa Clara, CA, 95054

159 USA) using $\mathrm{CO}_{2}$ as a transition medium. The specimens were mounted on

160 aluminium SEM stubs with carbon paint and coated with a layer of gold with a

161 Sputter Coater SCD 050 (Bal-Tec, Balzers, Lietchtenstein). Specimens were

162 viewed on a Zeiss DSM 940 Digital Scanning Microscope (Oberkochen,

163 Germany) at either 10 or $20 \mathrm{kV}$.

164

165 In spite of certain shrinking that could originate from sample treatment for SEM,

166 the technique used to dehydrate the samples consisted of gradually replacing

167 water with ethanol followed by the replacement of ethanol with $\mathrm{CO}_{2}$. After that,

$168 \mathrm{CO}_{2}$ was quickly sublimated to leave a dry sample. This technique allows the

169 preservation of the original structure of the sample as much as possible. Thus, we

170 can assume that even though the microstructure of the cheese might have changed

171 during the process, the structure observed in the micrographs is close to the 172 original. 
176 Texture profile analysis was carried out in a TA.XT2i Texture analyser (Stable

177 Micro Systems, Texture Technologies Corp., White Plains, N.Y.). Cylindrical

178 samples were obtained from the centre of 15-day ripened cheese pieces using a

179 0.5-inch borer. Their height was adjusted to $1.1 \mathrm{~cm}$ with a blade. Samples were

180 placed into Petri dishes and kept at $20^{\circ} \mathrm{C}$ for $1 \mathrm{~h}$; afterwards, they were compressed

$18160 \%$ in two cycles using the P50 probe and a crosshead speed of $120 \mathrm{~mm} \cdot \mathrm{min}^{-1}$;

182 five samples of every cheese were analysed. The values of the textural

183 characteristics, hardness, springiness, cohesiveness and chewiness, were

184 calculated from the resulting curves by means of the equipment software (Texture

185 Expert 1.20, Stable Micro Systems Ltd. 1998) (11).

186

187 Sensory evaluation

188

189 A selected and trained panel of 10 members was used for the sensorial texture

190 evaluation. Selection of the panel was done using duo-trio and triangle tests to

191 differentiate commercial cheeses based on textural attributes. The selected

192 members of the panel were trained using duo-trio, triangle tests, and ranking

193 multi-sample tests through several sessions. Additional sessions were done to

194 fully define textural attribute descriptors and scales knowledge. Training sessions

195 were done with five commercial cheeses for every attribute. To evaluate the

196 textural attributes, the method of scaling was used by means of a $10-\mathrm{cm}$

197 unstructured scale with references at the ends and the evaluated attributes were:

198 hardness, springiness, cohesiveness and chewiness. Cheese produced with either 
199 ropy or non-ropy starter cultures were evaluated by the quantitative description 200 analysis technique. Samples were prepared by cutting cubical portions of 201 approximately $1 \mathrm{~cm}$ per side, kept at room temperature for $1 \mathrm{~h}$ before tasting, and 202 coded using random three-digit numbers.

203

\section{Statistical analyses}

206 All results were analysed by analysis of variance (ANOVA) using the Statistical 207 Analysis Software (Statistica 5.0, Stat Soft, Tulsa, OK, USA), with $P<0.05$ used 208 as the threshold for statistical significance.

\section{RESULTS}

\section{Milkfermentation}

213 Results obtained for $\mathrm{pH}$, acidity and apparent viscosity during milk fermentation 214 with either control or the ropy strain are shown in Fig. 1. There were no 215 significant differences in $\mathrm{pH}(P=0.0928)$ and acidity $(P=0.5835)$ in milk 216 fermented with either culture during the whole fermentation process. Fig. 1

217 illustrates that the apparent viscosity of milk fermented with either the control or 218 the ropy strain remained constant and equal for both cultures during the first hour $219(P=1.000$ for time and $P=0.98$ between cultures $)$, and increased slightly $(P=$ $220 \quad 0.0007$ for time), but still with no difference between the control and the ropy 221 culture $(P=0.98)$, up to 90 min of fermentation. When the $\mathrm{pH}$ reached a value 222 below 6.2 (after 120 min of fermentation), the apparent viscosity of the ropy strain 
223 culture increased significantly $(P<0.02)$ with respect to the control, despite the 224 fact that $\mathrm{pH}$ diminished equally for both cultures.

226 Yield and chemical composition of the cheese

228 The yield of manchego-type cheese was significantly higher $(P=0.0003)$ for the 229 ropy strain cheese than for the control. Table 1 shows the cheese yield before and 230 after salting and in the final product. The increase in yield was statistically 231 significant $(P<0.001)$ at the three stages of production, demonstrating the effect of 232 EPS. Composition analysis of the cheese is shown in Table 2, where it can be 233 observed that water and fat contents are higher in the ropy strain cheese with a 234 slight decrease in total protein content. Fig. 2 shows the loss of weight of cheese 235 during ripening, demonstrating a greater loss of water in the control cheese.

Microstructure

239 Figs. 3 and 4 show the microstructure by scanning electron microscopy (SEM) of 240 all the sections of both control and ropy strain cheese. Microscopic studies of the 241 control cheese demonstrated no EPS production (Fig.3) and a three-dimensional 242 protein matrix formed by casein micelles to which microorganisms adhered. SEM 243 showed that in the ropy strain cheese (Fig. 4), the protein network had more and 244 larger open cavities than the control (Fig. 3). The polymer in the ropy strain 245 cheese could be seen as part of the network binding to the protein matrix and to 246 the fat globules; moreover, the number of visible fat globules was higher than in 247 the control cheese. 
249 As manchego-type cheese is a pressed cheese, a different microstructure was 250 expected across the different sections of the cheese. Due to this, for the SEM, 251 three different sections of the cheese were observed: the centre, the middle and the 252 rind. The cheese microstructure was different in the different sections studied: the 253 cavities in the protein matrix were wider in the centre than in the outer sections of 254 the cheese, which is in agreement with the fact that the centre retained more water 255 than the rind. Furthermore, comparison of the three sections showed that there 256 was a higher concentration of EPS in the centre than in the rind (Fig.4 a, b and c).

258 Instrumental texture profile analysis (TPA)

260 Fig.5 shows representative TPA curves obtained for both kinds of cheeses. From 261 these force-time graphs, the following parameters were evaluated: hardness, 262 cohesiveness, springiness and chewiness, which were calculated according to 263 Bourne (11). Table 3 shows the mean values of these TPA parameters and their 264 standard deviation. Hardness and springiness were significantly lower $(P<0.0001$, $265 P=0.0299$ respectively) in the ropy strain cheese, while cohesiveness was 266 significantly higher $(P=0.0321)$ and chewiness was not significantly different $(P=$ 267 0.1184) between the two kinds of cheese.

269 Sensory evaluation

271 The same textural attributes that were evaluated by TPA were also assessed by 272 their sensorial appraisal by a trained panel. Results are shown in Fig. 6 and in this 
273 case hardness and cohesiveness were significantly lower $(P<0.03)$ in the ropy

274 strain cheese than in the control, while springiness was significantly higher $(P=$

275 0.0299). Chewiness, on the other hand, was not perceived as significantly

276 different by the panellists $(P=0.3629)$.

277

278 DISCUSSION

279

280 Milkfermentation

281

282 The decrease in $\mathrm{pH}$ together with the increase in acidity observed for both cultures

283 (Fig. 1) indicate that the starter cultures developed as expected. When analysing

284 the apparent viscosity obtained with both cultures (Fig. 1) it was observed that it

285 remained almost the same until a $\mathrm{pH}$ of 6.2 was reached. After that point, the

286 apparent viscosity of the ropy strain culture increased significantly despite the fact

287 that $\mathrm{pH}$ diminished very similarly for both cultures. The measurement of apparent

288 viscosity (Fig. 1) was used as an indirect indicator of EPS production. The

289 changes in casein conformation due to acidification modify the apparent viscosity

290 of acidified milk. Nevertheless, it is generally agreed that even though there is no

291 straight relationship between an increase in viscosity and the concentration of

292 EPS, when EPS is produced the viscosity of the medium increases $(1,12,13,14)$.

293 Therefore, the higher increase in apparent viscosity of milk fermented with the

294 ropy culture indicates that EPS was produced.

295

296 Yield and chemical composition of the cheese

297 
298 The yield of manchego-type cheese at the three stages of production was higher 299 when the ropy strain was used $(P<0.001)$, with an increase of $10.9 \%$ of the final

300 product $(P=0.0003)$ (Table 1$)$. Before salting, an increase of $10.8 \%$ was observed $301(P=0.0002)$, reflecting the retention, despite the pressing procedure, of water and

302 fat because of their interactions with the EPS. Since salting was done by

303 submerging in brine, some water could be absorbed by the cheese to increase its

304 weight, as seen in the control cheese, which showed a significant increase

$305(P=0.0468)$ of $4.54 \%$. The ropy strain cheese did not show a significant increase

306 in weight $(P=0.8765)$, most likely because after pressing, EPS was already

307 holding as much water as it could and could not absorb any more. During

308 ripening, loss in weight occurs due to the evaporation of water. As shown in Fig.

3092 , the ropy strain cheese lost significantly less water than the control cheese

310 (16.65\% for the ropy and $19.16 \%$ for the control, $P=0.0003$ ) as a consequence of

311 the ability of EPS to retain moisture efficiently. An increment in yield between

31213.7 and $16.8 \%$ in Mexican panela cheese has been reported when an EPS-

313 producing culture is used (9). However, panela is a fresh cheese with high

314 moisture content, while manchego-type is a pressed and ripened cheese.

315 Therefore, a lower increase in the yield was expected, but the increase in the yield

316 was statistically significant $(P=0.0003)$, demonstrating the effect of EPS on

317 cheese yield. Observing the composition of the two types of cheese (Table 2),

318 yield improvement could be related to higher moisture and fat retention in the

319 ropy culture cheese than in the control. Similar conclusions were reported by

320 Rynne et al. (8) in half-fat cheddar cheese made with a ropy culture; they obtained

321 higher moisture and milk fat content, and an increase in the actual cheese yield. 
323 Total protein content (Table 2) decreased slightly in the ropy strain cheese. As

324 reported elsewhere, the ropy behaviour of EPS-producing strains might be due to

325 a complex relationship between the exopolysaccharides and milk proteins beyond

326 the sole production of the EPS, which has been explained partially by texture

327 profile analysis by Dominguez-Soberanes et al. (15), who determined that the

328 higher the protein content, the more EPS-protein interactions occur in milk,

329 leading to enhanced texture properties of the product. However, despite protein

330 concentration, EPS-protein interactions contributed to the textural characteristics

331 of the product, which was observed as an increase in viscosity during milk

332 fermentation due to the matrix formed by caseins and EPS, as suggested by Hess

333 et al. (16) and Dominguez-Soberanes et al. (15). This matrix could retain more fat

334 and water as demonstrated in the chemical analysis of the cheese (Table 2).

336 Microstructure

337

338 A higher water or fat content would change the cheese microstructure. To

339 evaluate the effect of EPS on cheese microstructure, SEM was used. Microscopic

340 studies of control cheese (Fig. 3) demonstrated no EPS production and a three-

341 dimensional protein matrix formed by casein micelles to which microorganisms

342 adhered. This is in accordance with other reports $(15,16)$. 343

344 SEM of the ropy strain cheese (Fig. 4) showed that the protein network had more 345 and larger open cavities than the control. These cavities contained higher amounts 346 of water, possible due to the interactions of EPS with milk components and the 347 protein matrix of the cheese, as observed in the SEM micrographs (Fig. 4) that 
348 show the interaction between EPS and the protein matrix leading to larger hollow 349 spaces than in the control cheese. Data reported in Table 2 confirm the higher 350 retention of water and fat within the cheese, hence increasing the yield. These 351 results agree with those reported by Hassan et al. (6) who observed by confocal 352 scanning laser microscopy a more open structure in feta cheese made with a 353 capsule-forming culture of $S$. thermophilus. Guzel-Seydim et al. (13) reported that 354 EPS strongly bound to water within the cheese matrix, retaining it for a longer 355 time than the control cheese. This was observed during the ripening of the cheese,

356 in which the ropy strain cheese retained more water than the control (Fig. 2).

358 The cheese microstructure was different along the different sections studied: the

359 cavities in the protein matrix were wider in the centre than in the outer sections of 360 the cheese, since the centre retained more water than the rind. Comparison of 361 the three sections of the ropy strain cheese (Fig. 4a,b,c) demonstrated that there 362 was a higher concentration of EPS in the centre than in the rind. It seems that the 363 production of EPS continued during ripening and occurred more frequently in the 364 centre where higher moisture content and an anaerobic environment was found 365 compared to the outer sections like the rind, where moisture is lower and oxygen 366 concentration higher. Thus, the environment influences the growth of bacteria 367 and/or EPS production.

369 Instrumental texture profile analysis (TPA)

371 The higher content of water and fat in the ropy strain cheese (Table 2) contributes

372 to a more open structure (Figs. 3 and 4), leading to a softer cheese that is also 
373 more cohesive but less elastic (Table 3 ). This could be explained by the fact that

374 higher fat and water contents tend to weaken the protein structure, resulting in a

375 softer cheese, as has been reported by several authors (17, 18, 19). Additionally,

376 according to Chen et al. (20) and Emmons et al. (21), higher fat content results in

377 smoother and softer cheese. Furthermore, data reported by Bryant et al. (22)

378 regarding cheddar cheese with different fat contents established that the

379 microstructure of lower-fat cheese had a more compact protein matrix with less

380 open spaces that would have otherwise been occupied by fat globules. This is

381 associated with a harder texture, even when the moisture content is high. These

382 authors also showed that the open-intricate microstructure of the cheese analysed

383 by SEM was lost, accompanied by a decrease in fat content. The same effect can

384 be observed in Figs. 3 and 4, where the ropy strain cheese shows a more open

385 structure, with milk fat globules observed within the protein matrix. All these

386 findings are in accordance with data reported by Lobato-Calleros et al. (23) who

387 observed that in Mexican manchego-type cheese, the reduction of fat resulted in a

388 harder cheese due to the compact and denser larger areas of protein matrix

389 uninterrupted by fat globules.

390

391 Moreover, it is well established that cheese with higher moisture are less firm than

392 their lower-moisture counterparts due to the fact that the hydrophobic interactions,

393 important for stabilising casein matrix structure, are weakened by adsorption of

394 water by proteins $(24,17)$. This could contribute to the softer texture found in the

395 ropy strain cheese. Since EPS increased water and fat contents, these factors could

396 have primarily contributed to a softer cheese when the ropy culture was used.

397 However, beyond the augmented content of water and fat in the ropy strain 
398 cheese, EPS and its interaction with proteins and other cheese constituents should

399 influence the texture profile. Cohesiveness is expected to diminish as water and

400 fat contents increase (22), but on the other hand, interactions between EPS and

401 milk components, mainly proteins, could increase cohesiveness in the ropy strain

402 cheese, as has been established by Dominguez-Soberanes et al. (15), who

403 suggested that an interaction between EPS and caseins increased cohesiveness in

404 fermented milk. In a solid product, cohesiveness represents how well its structure

405 withstands a deformation and/or tearing apart; the higher cohesiveness of the ropy

406 strain cheese found in this study suggests a strong interaction between EPS and

407 caseins of the cheese matrix, in spite of the higher fat and water contents.

408

409 The results in springiness showed a less elastic ropy strain cheese than control.

410 Bryant et al. (22) reported that springiness in cheddar cheese increased with

411 decreasing fat content, consistent with Emmons et al. (21) who established that

412 reduced fat cheese tends to be more elastic. Based only on fat content, our results

413 would be in agreement with those reported by Emmons et al. (21) and Bryant et

414 al. (22). However, the effect of moisture content on springiness is not clear, and

415 both increases and decreases in springiness with moisture content have been

416 reported (24).

417

418 It is clear that the relationship between cheese composition and its texture profile

419 is very complex, and that other factors, such as process conditions and microbiota,

420 might also influence the texture of the product. This makes it hard to establish a

421 straight relationship between the components and the texture profile alone, as has 
422 been reported by van Hekken et al. (25) and Tunick et al. (26) for Chihuahua

423 cheese, which is similar to the Mexican manchego-type cheese.

424

425 Sensory evaluation

426

427 Despite the fact that instrumental TPA is designed to simulate consumer

428 perception of the physical properties of foods, human perception of the textural

429 properties of food depends on many complex factors that the instrument does not

430 consider on the whole while making the measurements. Because of this, it is

431 always important to measure both instrumental and sensory perception of the

432 texture of a product.

433

434 When comparing the results obtained in the TPA with those obtained by sensory

435 evaluation (Fig. 6), a direct correlation was found for hardness and chewiness. In

436 both cases, hardness was higher for the control than for the ropy strain cheese,

437 which (as discussed above) could be due to the higher water and fat contents of

438 the ropy strain cheese. There was no significant difference in the chewiness of

439 both types of cheese. The other parameters, cohesiveness and springiness, were

440 perceived differently by the panellists compared to the instrument.

441

442 It is clear that the same textural attributes are not necessarily perceived equally by

443 the human senses and an instrument, even when equipments such as the texture

444 analyser have been designed to mimic consumer texture perception. This has been

445 pointed out by Marshall (27) and Jack et al. (28). The texturometer can

446 simultaneously quantify a number of textural properties, although only hardness 
447 has been shown to relate well to data obtained from sensory analysis. Fracture 448 patterns obtained by human actions differ markedly from those produced by

449 instruments $(27,17)$.

450

451 In summary, the use of the exopolysaccharide-producing strain of S. thermophilus

452 SY-102 in Mexican manchego-type cheese increased moisture and fat retention 453 within the cheese matrix. This was reflected in the greater yield of cheese 454 obtained. Scanning electron microscopy showed that EPS bound to the protein 455 matrix of the cheese, microorganisms and milk fat globules, leading to a more 456 open structure of the cheese and producing an EPS-protein network that helped 457 increase water and fat retention. Furthermore, interactions between EPS and water 458 were strong enough to retain moisture during cheese ripening.

460 The higher water and fat contents of the ropy strain cheese was reflected in a 461 change in the textural characteristics, hardness being the most significant and also 462 perceived by the sensory evaluation panellists. The changes in textural 463 characteristics were related to the changes in cheese composition: hardness 464 increased as water and fat decreased, while springiness decreased with increasing 465 fat. The interactions of EPS with the protein matrix of the cheese affected 466 cohesiveness, increasing it in the ropy strain cheese. The composition of the 467 cheese also influenced its sensory characteristics, giving a softer texture in the 468 ropy than the control cheese. Other textural parameters, such as cohesiveness and 469 elasticity, were perceived differently by the panellists and the texturometer. 470

\section{$471 \quad$ References}


473 (1) Wacher-Rodarte C.; Galván M.V.; Farrés A.; Gallardo F.; Marshall V.M.E.;

474 Garcia-Garibay M. Yogurt Production from Reconstituted Skim Milk

475 Powders Using Different Polymer and Non-Polymer Forming Starter

476 Cultures. Journal of Dairy Research. 1993, 60, 247-254.

477 (2) Hassan A.; Frank J.F. Modification of Microstructure and Texture of Rennet

478 Curd by Using a Capsule-Forming Non-Ropy Lactic Culture. Journal of

479 Dairy Research. 1997, 64, 115-121.

480 (3) Perry D.B.; McMahon D.J.; Oberg C.J. Effect of Exopolysaccharide481 Producing Cultures on Moisture Retention in Low Fat Mozzarella Cheese. 482 Journal of Dairy Science. 1997, 80, 799-805.

483 (4) Low D.; Ahlgren J.A.; Horne D.; McMahon D.J.; Oberg C.J.; Broadbent J.R. $484 \quad$ Role Of Streptococcus thermophiles MR-1C Capsular Exopolysaccharide 485 in Cheese Moisture Retention. Applied and Environmental Microbiology. $486 \quad 1998,64,2147-2151$.

487 (5) Petersen B.L.; Dave R.I.; McMahon D.J.; Oberg C.J.; Broadbent J.R. 488 Influence Of Capsular And Ropy Exopolysaccharide-Producing 489 Streptococcus thermophilus on Mozzarella Cheese and Cheese Whey. $490 \quad$ Journal of Dairy Science. 2000, 83, 1952-1956.

491 (6) Hassan A.N.; Frank J.F.; Corredig M. Microstructure of Feta Cheese Made 492 Using Different Cultures as Determined by Confocal Scanning Laser 493 Microscopy. Journal of Food Science.2002, 67, 2750-2753.

494 (7) Hassan A.N.; Corredig M.; Frank J.F.; Elsoda M. Microstructure and 495 Rheology of an Acid-Coagulated Cheese (Karish) Made with an 496 Exopolysaccharide-Producing Streptococcus thermophilus Strain and its 

Research. 2004, 71, 116-120.

(8) Rynne N.M.; Beresford T.P.; Kelly A.L.; Tunick M.H.; Malin E.L.; Guinee 500 T.P. Effect of Exopolysaccharide-Producing Adjunct Starter Cultures on the Manufacture, Composition and Yield of Half-Fat Cheddar Cheese. Australian Journal of Dairy Technology. 2007, 62, 12-18.

(9) Jiménez-Guzmán J.; Flores-Nájera A.; Cruz-Guerrero A.E.; García-Garibay M. Use Of An Exopolysaccharide-Producing Strain of Streptococcus thermophilus in the Manufacture of Mexican Panela Cheese. LWT-Food Science and Technology.2009, 42, 1508-1512.

(10) Yong K.J.; Young W.P. SDS-PAGE of Proteins in Goat Milk Cheeses Ripened under Different Conditions. Journal of Food Science.1996, 61, 490-495.

(11) Bourne, M.C. Food Texture and Viscosity: Concept and Measurement. Academic Press: New York, 1982.

(12) Broadbent J.R.; McMahon D.J.; Oberg C.J.; Welker D.L. Use of Exopolysaccharide-Producing Cultures to Improve the Functionality of Low Fat Cheese. International Dairy Journal. 2001, 11, 433-439.

(13) Guzel-Seydim Z.B.; Sezgin E.; Seydim A.C.; Influences of Exopolysaccharide Producing Cultures on the Quality of Plain Set Type Yogurt. Food Control.2005, 16, 205-209.

(14) Champagne C.P.; Barrette J.; Roy D.; Rodrigue N. Fresh Cheesemilk Formulation Fermented by a Combination of Freeze-Dried Citrate-Positive Cultures and Exopolysaccharide-Producing Lactobacilli with Liquid Lactococcal Starter. Food Research International.2006, 39, 651-659. 
522 523

(15) Dominguez-Soberanes J.; García-Garibay M.; Casas-Alencáster N.B.; Martínez-Padilla L.P. Instrumental Texture of Set and Stirred Fermented Milk. Effect of a Ropy Strain of Lactobacillus delbrueckii subsp. bulgaricus and an Enriched Substrate. Journal of Texture Studies.2001, 32, 205-217.

(16) Hess S.J.; Roberts R.F.; Zieglier G. Rheological Properties of Non-Fat Yogurt Stabilized Using Lactobacillus delbrueckii subsp. bulgaricus Producing Exopolysaccharide or Using Commercial Stabilizer Systems. Journal of Dairy Science.1997, 80, 252-263.

(17) Jack F.R.; Paterson A. Texture of Hard Cheeses. Trends in Food Science and Technology.1992, 3, 160-164.

(18) Tunick M.H.; Mackey K.L.; Shieh J.J.; Smith P.W.; Cooke P.; Malin E.L. Rheology and Microstructure of Low-Fat Mozzarella Cheese. International Dairy Journal.1993, 3, 649-662.

(19) Tunick M.H.; Malin E.L.; Smith P.W.; Shieh J.J.; Sullivan B.C.; Mackey K.L.; Holsinger V.H. Proteolysis and Rheology of Low-Fat and Full-Fat Mozzarella Cheeses Prepared from Homogenized Milk. Journal of Dairy Science.1993, 76, 3621-3628.

(20) Chen A.H.; Larkin J.W.; Clark C.J.; Irwin W.E. Textural Analysis of Cheese. Journal of Dairy Science.1979, 62, 901-907.

(21) Emmons D.B.; Kalab M.; Larmond E.; Lowrie R.J. Milk Gel Structure X. Texture and Microstructure in Cheddar Cheese Made from Whole Milk and Homogenized Low-Fat Milk. Journal of Texture Studies.1980, 11, 1534. 
546 (22) Bryant A.; Ustunol Z.; Steffe J. Texture of Cheddar Cheese as Influenced by 547 Fat Reduction. Journal of Food Science.1995, 60, 1216-1219, 1236.

(23) Lobato-Calleros C.; Robles-Martínez J.C.; Caballero-Perez J.F.; AguirreMandujano E.; Vernon-Carter E.J. Fat Replacers in Low-Fat Mexican Manchego Cheese. Journal of Texture Studies.2001, 32, 1-14.

(24) Tunick M.H.; Mackey K.L.; Smith P.W.; Holsinger V.H. Effects of Composition and Storage on the Texture of Mozzarella Cheese. Netherlands Milk and Dairy Journal. 1991, 45, 117-125.

(25) Van Hekken D.L.; Tunick M.H.; Tomasula P.M.; Molina-Corral F.J.; Gardea A.A. Mexican Queso Chihuahua: Rheology of Fresh Cheese. International Journal of Dairy Technology.2007, 60, 5-12.

(26) Tunick M.H.; Van Hekken D.L.; Call J.; Molina-Corral F.J.; Gardea A.A. Queso Chihuahua: Effects of Seasonality of Cheesemilk on Rheology. International Journal of Dairy Technology.2007, 60, 13-21.

(27) Marshall R.J. Composition, Structure, Rheological Properties, and Sensory Texture of Processed Cheese Analogues. Journal of the Science of Food and Agriculture.1990, 50, 237-252.

(28) Jack F.R.; Paterson A.; Piggott J.R. Relationships between Rheology and Composition of Cheddar Cheeses and Texture as Perceived by Consumers. International Journal of Food Science and Technology.1993, 28, 293-302. 
566

567

\section{Figure captions}

569 Figure 1. Apparent viscosity $(\eta), \mathrm{pH}$ and acidity changes during milk

570 fermentation. $\square \mathrm{pH}$ control, $\square \mathrm{pH}$ ropy, $\Delta \eta$ control, $\Delta \eta$ ropy, Oacidity control,

571 acidity ropy.

572

573 Figure 2. Weight variation in cheese during ripening. $\square$ control, $\square$ ropy

574

575 Figure 3. Microstructure (x 5000) of three different sections of control Mexican

576 manchego-type cheese: (a) rind, (b) medium and (c) centre. The scale bar

577 indicates $5 \mu \mathrm{m}$.

578

579 Figure 4. Microstructure (x 5000) of three different sections of ropy Mexican

580 manchego-type cheese: (a) rind, (b) medium and (c) centre. The scale bar

581 indicates $5 \mu \mathrm{m}$.

582

583 Figure 5. TPA curves obtained for the two kinds of cheese. -- Control, -ropy 584

585 Figure 6. Comparison of the sensory attributes of ropy and control Mexican

586 manchego-type cheese. $\square$ control, $\square$ ropy. 


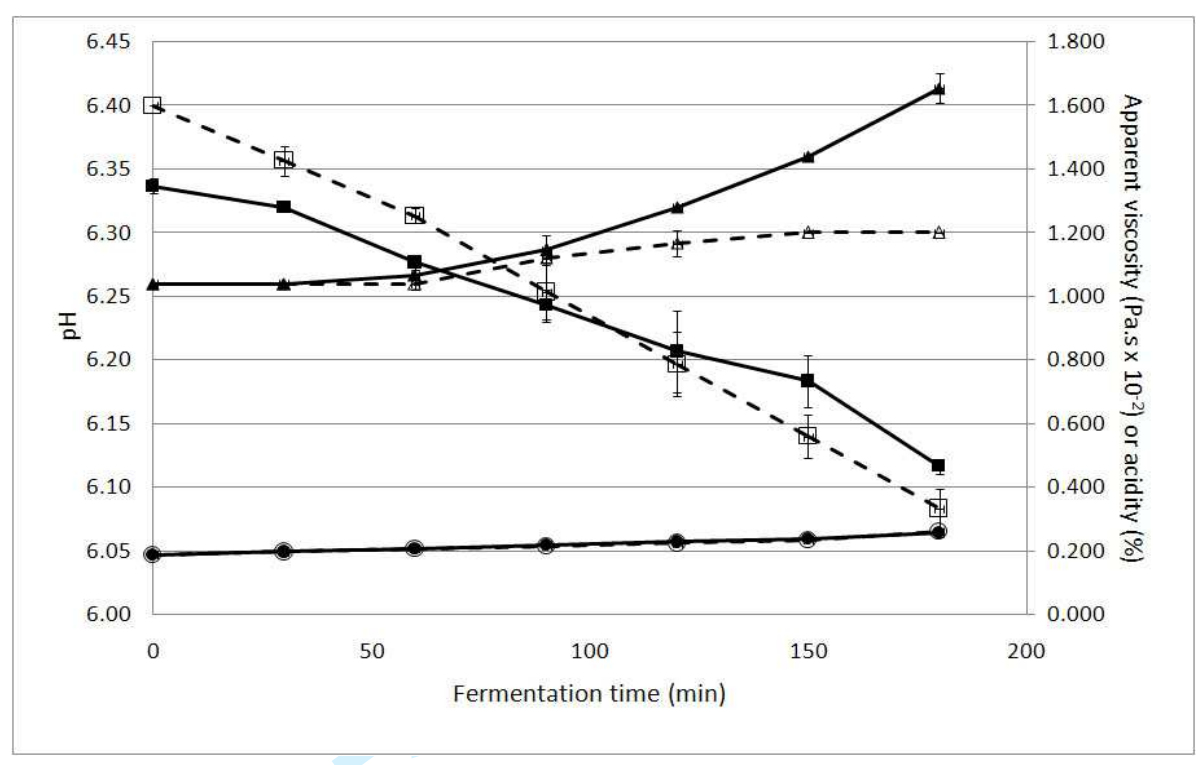

588 Figure 1. Apparent viscosity $(\eta), \mathrm{pH}$ and acidity changes during milk

589 fermentation. $\square \mathrm{pH}$ control, $\boldsymbol{\square} \mathrm{pH}$ ropy, $\triangle \eta$ control, $\boldsymbol{\Delta} \eta$ ropy, $\bigcirc$ acidity control, $590 \bigcirc$ acidity ropy 


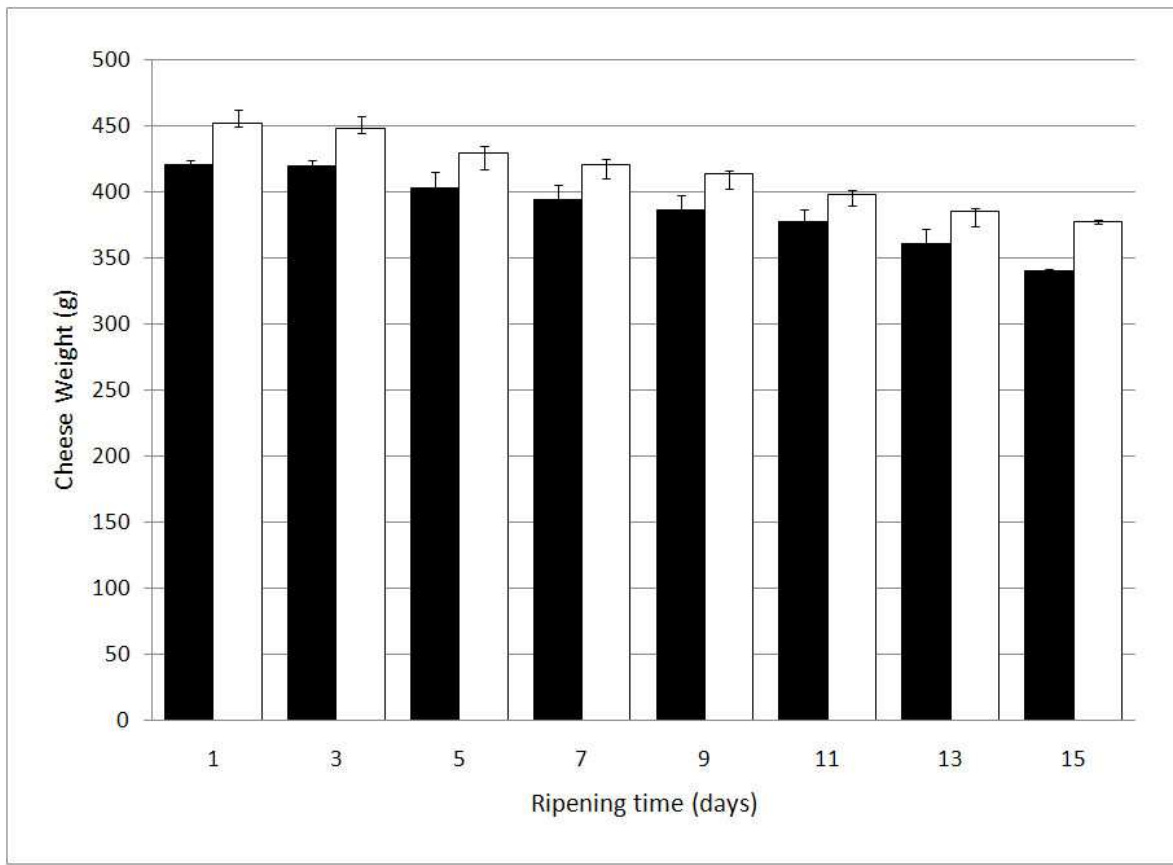

592 Figure 2. Weight variation in cheese during ripening. $\square$ control, $\square$ ropy 


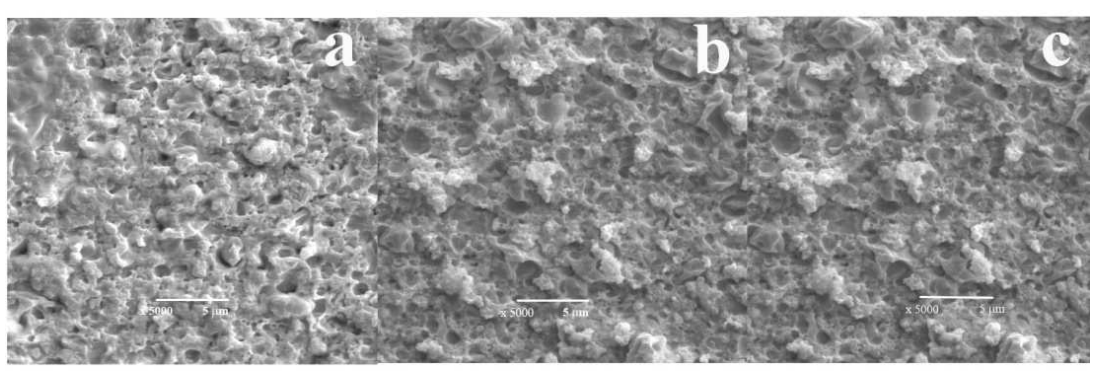

594 Figure 3. Microstructure (x 5000) of three different sections of control Mexican 


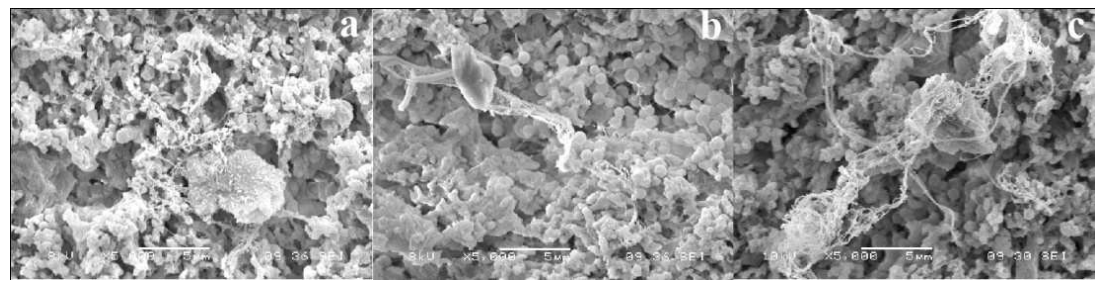

598 Figure 4. Microstructure (x 5000) of three different sections of ropy Mexican

599 manchego-type cheese: (a) rind, (b) medium and (c) centre. The scale bar

600 indicates $5 \mu \mathrm{m}$. 


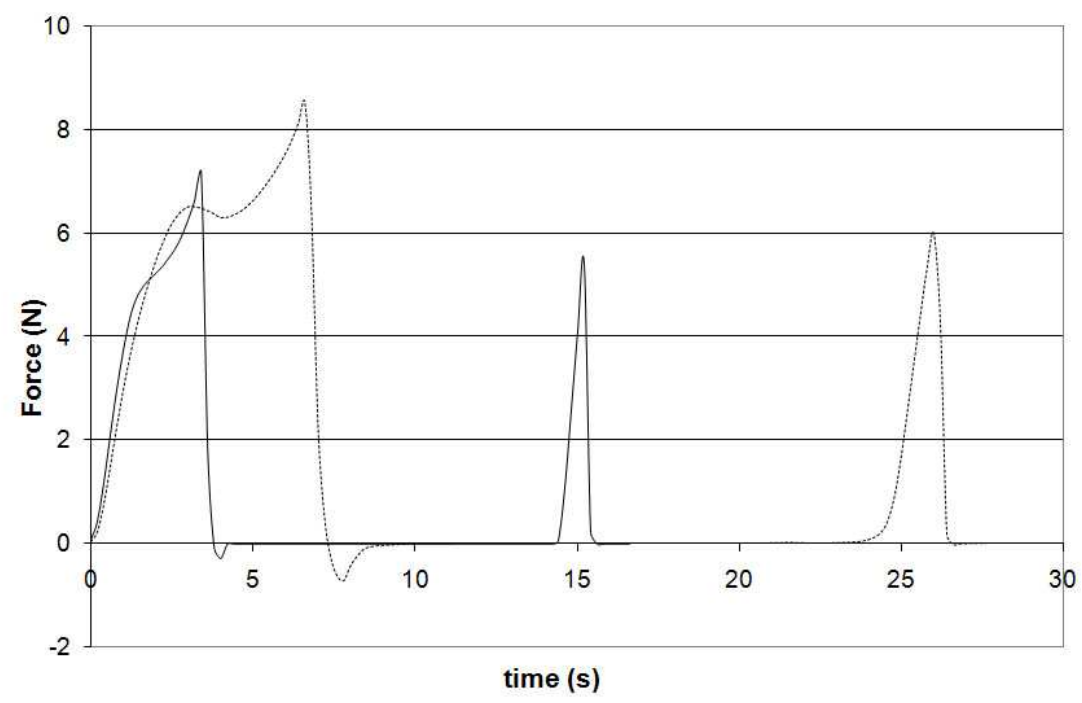

601

602 Figure 5. TPA curves obtained for the two kinds of cheese. -- Control, -ropy 603 


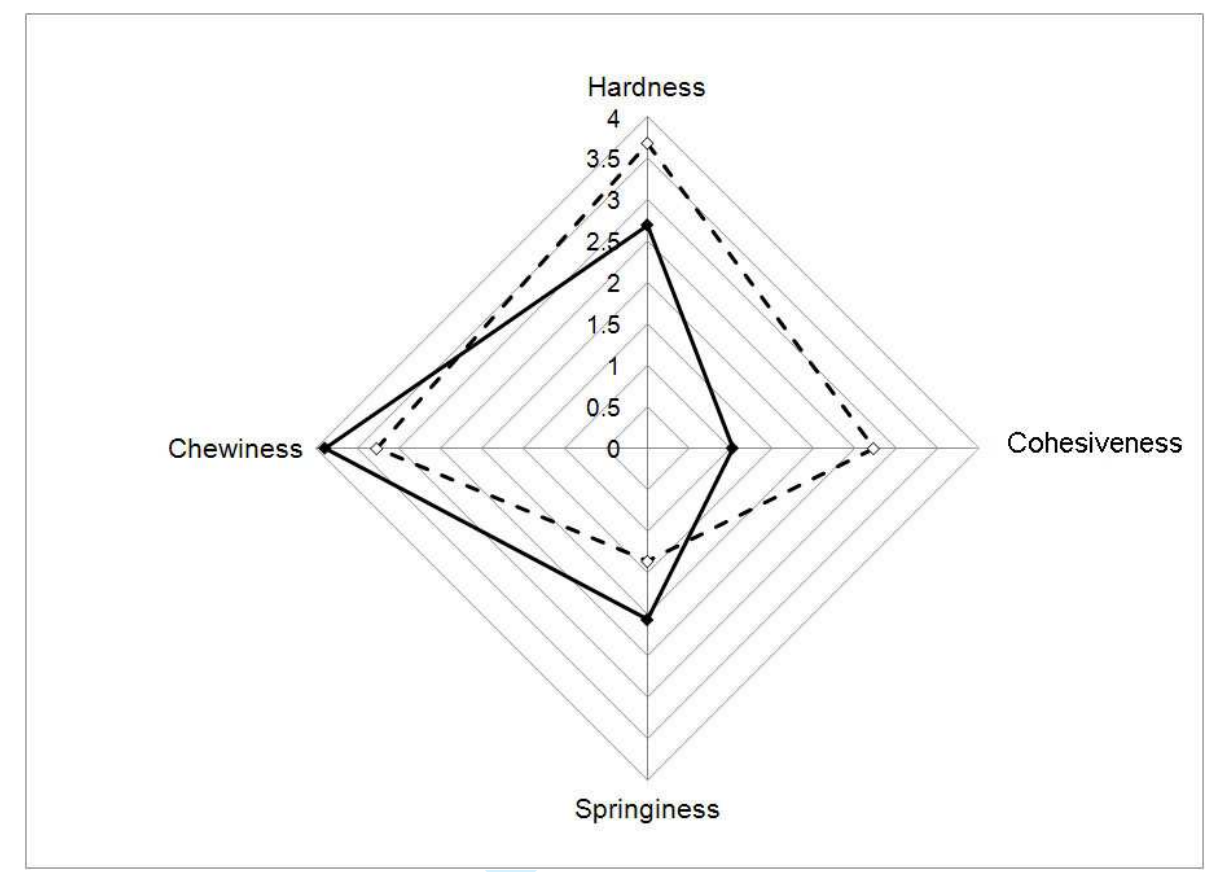

605 Figure 6. Comparison of the sensory attributes of ropy and control Mexican

606 manchego-type cheese. $\square$ control, $\square$ ropy. 
608 Table 1. Cheese yield.

\begin{tabular}{|c|c|c|c|}
\hline & Before salting & After salting & After ripening \\
\hline Control cheese & $11.16 \pm 0.19^{\mathrm{a}}$ & $11.67 \pm 0.07^{\mathrm{c}}$ & $9.43 \pm 0.04^{\mathrm{d}}$ \\
\hline Ropy-strain cheese & $12.37 \pm 0.28^{\mathrm{b}}$ & $12.53 \pm 0.28^{\mathrm{b}}$ & $10.45 \pm 0.06^{\mathrm{e}}$ \\
\hline \% enhancement of yield & 10.8 & 7.4 & 10.9 \\
\hline
\end{tabular}

$610 \quad(P<0.001)$. 
611 Table 2. Chemical composition of the cheese $\left(\mathrm{g} \cdot 100 \mathrm{~g}^{-1}\right)$.

\begin{tabular}{|c|c|c|c|c|c|c|}
\hline & TS & Moisture & Fat & $\begin{array}{c}\text { Total } \\
\text { protein }\end{array}$ & $\begin{array}{c}\text { Fat } \\
(\mathbf{d w b})\end{array}$ & $\begin{array}{c}\text { Total } \\
\text { protein } \\
(\mathbf{d w b})\end{array}$ \\
\hline $\begin{array}{c}\text { Control } \\
\text { cheese }\end{array}$ & $59.7 \pm 0.5^{\mathrm{a}}$ & $40.3 \pm 0.5^{\mathrm{a}}$ & $30 \pm 0.0^{\mathrm{a}}$ & $21.0 \pm 1.2^{\mathrm{a}}$ & $50.3 \pm 1.0^{\mathrm{a}}$ & $35.3 \pm 0.6^{\mathrm{a}}$ \\
\hline $\begin{array}{c}\text { Ropy strain } \\
\text { cheese }\end{array}$ & $55.3 \pm 0.2^{\mathrm{b}}$ & $44.7 \pm 0.2^{\mathrm{b}}$ & $34 \pm 0.0^{\mathrm{b}}$ & $19.0 \pm 1.0^{\mathrm{a}}$ & $61.5 \pm 1.0^{\mathrm{b}}$ & $34.3 \pm 0.1^{\mathrm{b}}$ \\
\hline
\end{tabular}

612

TS = total solids, NFS = non-fat solids, dwb = dry weight basis

$61 a^{\mathrm{a}, \mathrm{b}}$ Different superscript letters in the same column indicate significantly different

614 values $(P<0.005)$ 
615 Table 3. Textural characteristics of ropy and control cheese.

\begin{tabular}{|l|c|c|c|c|}
\hline & $\begin{array}{c}\text { Hardness } \\
(\mathrm{N})\end{array}$ & Cohesiveness & $\begin{array}{c}\text { Springiness } \\
(\mathrm{mm})\end{array}$ & $\begin{array}{c}\text { Chewiness } \\
(\mathrm{Nmm})\end{array}$ \\
\hline $\begin{array}{l}\text { Control } \\
\text { cheese }\end{array}$ & $8.67 \pm 0.26^{\mathrm{a}}$ & $0.15 \pm 0.02^{\mathrm{a}}$ & $6.90 \pm 0.42^{\mathrm{a}}$ & $8.96 \pm 1.21^{\mathrm{a}}$ \\
\hline $\begin{array}{l}\text { Ropy } \\
\text { strain } \\
\text { cheese }\end{array}$ & $6.73 \pm 0.47^{\mathrm{b}}$ & $0.18 \pm 0.01^{\mathrm{b}}$ & $6.24 \pm 0.38^{\mathrm{b}}$ & $7.66 \pm 1.14^{\mathrm{a}}$ \\
\hline
\end{tabular}

617 values $(P<0.05)$.

618

619 